\author{
Universidade de Brasília \\ Instituto de Psicologia \\ Programa de Pós-graduação em Psicologia Clínica e Cultura
}

\title{
INFLUÊNCIAS DE MÍDIAS SOCIAIS NA CONSTRUÇÃO DE RELACIONAMENTOS HOMOAFETIVOS
}

\author{
Luiz Fernando Carvalho Maciel
}

Orientadora: Prof.: Gláucia Ribeiro Starling Diniz, PhD.

Brasília, 2014 


\title{
Universidade de Brasília \\ Instituto de Psicologia \\ Programa de Pós-graduação em Psicologia Clínica e Cultura
}

\section{INFLUÊNCIAS DE MÍDIAS SOCIAIS NA CONSTRUÇÃO DE RELACIONAMENTOS HOMOAFETIVOS}

\author{
Luiz Fernando Carvalho Maciel \\ Orientadora: Prof.: Gláucia Ribeiro Starling Diniz, PhD. \\ Dissertação apresentada ao Instituto de Psicologia \\ da Universidade de Brasília como requisito \\ parcial para obtenção do Grau de Mestre em \\ Psicologia Clínica e Cultura.
}

Brasília, 2014 
Trabalho apresentado ao Programa de Pós-Graduação em Psicologia Clínica e Cultura, Departamento de Psicologia Clínica, Instituto de Psicologia da Universidade de Brasília, para obtenção do grau de Mestre em Psicologia Clínica e Cultura, sob a orientação da Professora Gláucia Ribeiro Starling Diniz, Ph.D.

\section{Banca Examinadora:}

Presidente: Prof ${ }^{a}$. Gláucia Ribeiro Starling Diniz, Ph.D. Universidade de Brasília - UnB

Membro Externo: Prof ${ }^{\mathrm{a}}$. Dr$^{\mathrm{a}}$ Cristina Lopes de Almeida Amazonas, Universidade Católica de Pernambuco - UCPE

Membro Interno: Prof $^{\mathrm{a}}$. Dra ${ }^{\mathrm{a}}$.Valeska Maria Zanello Universidade de Brasília - UnB

$\overline{\text { Membro Suplente: Prof }}{ }^{a}$. Dr ${ }^{\mathrm{a}}$ Profa. Júlia S. N. F. Bucher-Maluschke Universidade de Brasília - UnB 


\section{AGRADECIMENTOS}

À minha mãe Luiza e meu pai Pery (in memoriam) por me ensinarem que o maior patrimônio que pode ser construído é a educação. Pelo apoio emocional e financeiro, por todo amor e carinho destinados a mim, meu eterno agradecimento.

À professora Gláucia Diniz, que por pouco consegue abraçar o mundo, muito obrigado por me acolher nesse abraço, pelo constante carinho, paciência e ensinamentos.

À professora Valeska Zanello que, ao lado de minha orientadora Gláucia, ampliou meu entendimento e perspectivas a respeito de feminismos e questões relacionadas a gênero.

À minha colega Greisy Vázquez, com quem tive a satisfação de ministrar em conjunto com a prof. Gláucia a disciplina Psicologia Conjugal e Familiar no primeiro semestre de 2013, na UnB. E, ainda, aos alunos que conviveram conosco durante o referido semestre, obrigado pela participação e interesse demonstrado nas aulas.

Aos casais participantes da presente pesquisa, pela disponibilidade, acessibilidade e interesse por contribuir para a construção do conhecimento acadêmico.

A todo grupo de pesquisa do Laboratório de Saúde Mental e Cultura da Universidade de Brasília, principalmente à companheira Cláudia de Oliveira Alves, pelas conversas e debates construtivos, além da generosidade de compartilharem suas experiências em pesquisa, ensino e extensão.

Às professoras Dra. Cristina Lopes de Almeida Amazonas, Dra. Valeska Maria Zanello e Dra. Júlia S. N. F. Bucher-Maluschke, muita gratidão por aceitarem o convite para participarem da banca de mestrado.

Às(os) colegas de trabalho que conviveram comigo durante esse período, pela compreensão e incentivo para a realização desse projeto.

Por fim, aos meus amigos que também se fizeram presentes, mesmo quando eu estava ausente em virtude do tempo dedicado à pesquisa, especialmente a Francisco Barcelos Junior, meus carinhosos agradecimentos por me resgatar em momentos difíceis nessa jornada. 


\section{ÍNDICE}

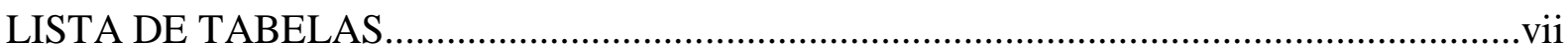

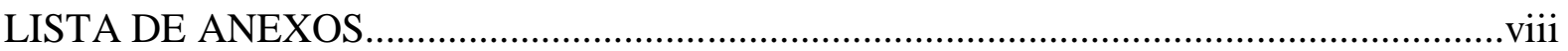

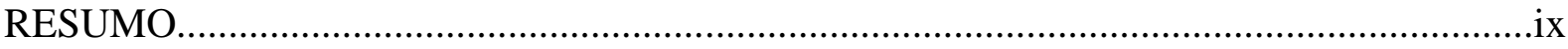

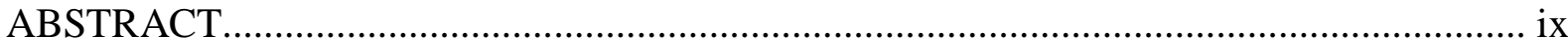

APRESENTAÇÃO

ARTIGO I - MASCULINIDADES E GERAÇÃO DE PRECONCEITOS ENTRE

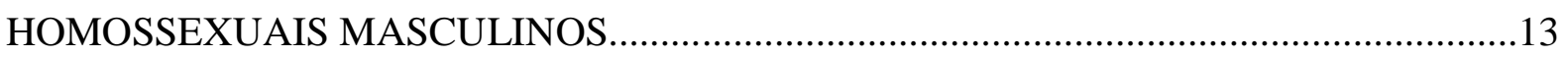

Masculino versus Feminino.................................................... 13

Homossexualidade masculina e elementos históricos do preconceito...........................15

O preconceito entre os homoafetivos - aspectos de masculinidades............................19

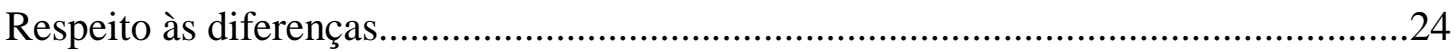

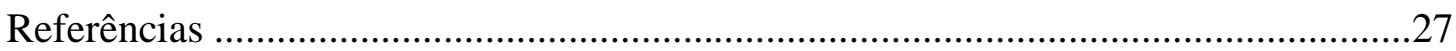

ARTIGO II - DESAQUENDA DE NÁRNIA: ASPECTOS DA (IN)VISIBILIDADE

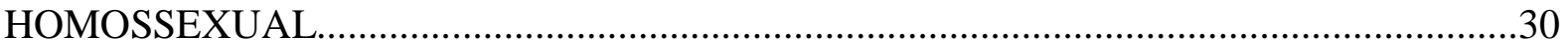

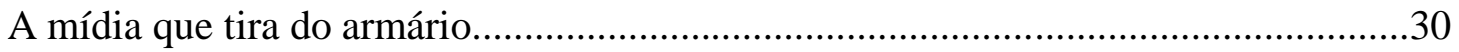

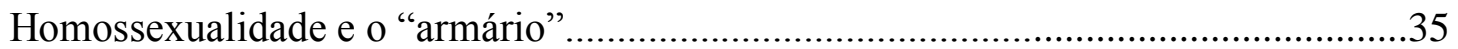

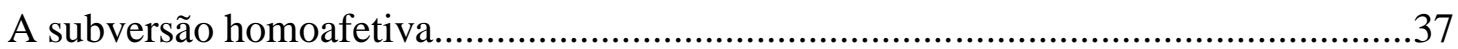

Visibilidade (ou invisibilidade?) acadêmica - levantamento de artigos........................41

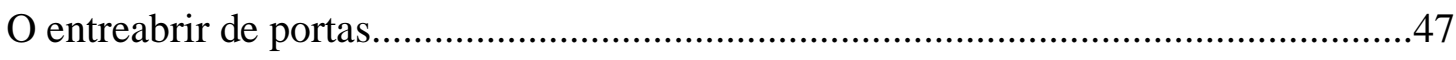

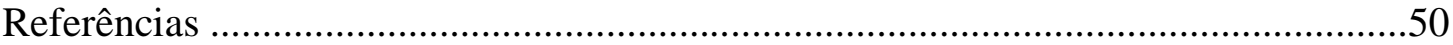

ARTIGO III - MONA, NÃO FAZ A EGÍPCIA! - UMA REVISÃO SISTEMÁTICA DE

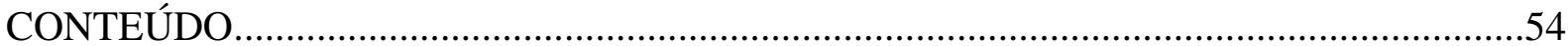

Guetos virtuais ou possibilidades contemporâneas?...................................................54

O lugar (papel) da internet e mídias sociais nas relações (homo)afetivas.....................57

Revisão sistemática de conteúdo de artigos sobre relacionamentos virtuais ...............61

Do contato virtual à vida real: questões e desafios.................................................... 71

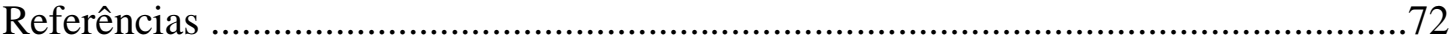


ARTIGO IV - INFLUÊNCIAS DA INTERNET E DE MÍDIAS SOCIAIS NA CONSTRUÇÃO DO VÍNCULO HOMOAFETIVO........................................................... 76

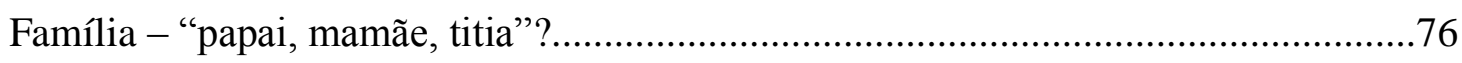

Família e conjugalidade contemporâneas...............................................................79

A influência da internet na construção da conjugalidade homoafetiva.........................85

O que elas e eles dizem? Uma análise de conteúdo de entrevistas com casais

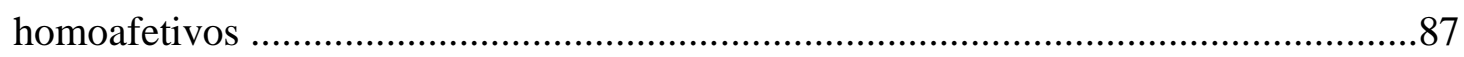

Discussão: do virtual ao real - dilemas e desafios....................................................96

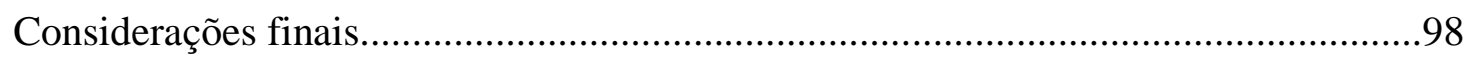

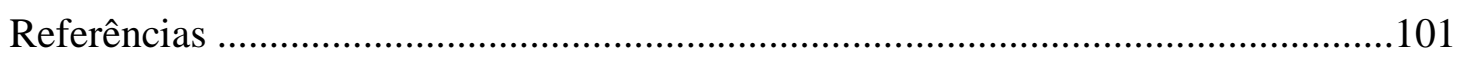

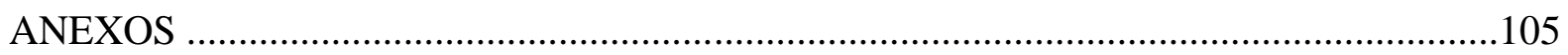

Termo de Consentimento Livre e Esclarecido - TCLE

Roteiro de entrevista semiestruturada

Parecer de aprovação emitida pelo Comitê de Ética 


\section{LISTA DE TABELAS}

\section{Artigo II}

Tabela 1: Descritores em português e/ou em periódicos nacionais

Tabela 2: Descritores em inglês em periódicos nacionais e internacionais

\section{Artigo III}

Tabela 1: Descritores de Busca Bibliográfica

Tabela 2: Resultado de Revisão sistemática no Scielo

Tabela 3: Resultado de Revisão sistemática no Pepsic

Tabela 4: Resultado de Revisão sistemática no Google Acadêmico (congressos e seminários)

\section{Artigo IV}

Tabela 1: Frequência dentro de cada tema 


\section{LISTA DE ANEXOS}

Anexo A -Termo de Consentimento Livre e Esclarecido - TCLE.

Anexo B - Roteiro de entrevista semiestruturada

Anexo C - Parecer de Aprovação do Comitê de Ética em Pesquisa 


\title{
RESUMO
}

As novas possibilidades de configurações dos relacionamentos contemporâneos têm sido objeto de estudo pela academia. A produção de conhecimento científico nessa área abrange estudos de gênero e sexualidade. O interesse por relações mediadas por tecnologias cresceu nos últimos anos. O objetivo geral dessa dissertação é compreender usos de mídias sociais na construção de relacionamentos homoafetivos masculinos e femininos. O trabalho foi dividido em quatro (4) artigos. O primeiro traçou um panorama histórico sobre homossexualidade e preconceito. O segundo e o terceiro buscaram dar visibilidade a publicações acadêmicas na área. $\mathrm{O}$ quarto apresenta e discute o conteúdo de entrevistas realizadas com casais homoafetivos. Os resultados dessa dissertação indicam que o debate acadêmico e a produção de dados sobre o tema ainda são incipientes, apesar da relevância do assunto. Fica evidente a necessidade de mais pesquisas nessa área. A construção desse conhecimento pode beneficiar a prática clínica em psicologia e em terapia conjugal e familiar.

Palavras chave: Gênero; Homossexualidade; Mídias Sociais; Conjugalidade; Visibilidade; Preconceito.

\begin{abstract}
The new possibilities of configurations of contemporary relationships have become a focus of academic research. The production of scientific knowledge in this area includes gender and sexuality studies. The interest regarding relations mediated by technology has grown in recent years. The overall objective of this master thesis is to understand the use of social media in the construction of male and female homosexual relationships. The thesis is divided in four (4) articles. The first covers a historical overview of homosexuality and prejudice. The second and third articles give visibility to academic publications in the area. The fourth presents and discusses data from interviews with homosexual couples. The results of this thesis indicate that the academic debate and data on the subject are still incipient, despite the relevance of the topic. The field needs research addressing new ways of relating, due to its importance for clinical practice in psychology and in marriage and family therapy.
\end{abstract}

Keywords: Gender; Homosexuality; Social Medias; Conjugality; Visibility; Prejudice. 


\section{APRESENTAÇÃO}

A internet surgiu comercialmente em Brasília em 1995 e desde o final do referido ano eu passei a acessar a rede mundial de computadores. Por falta de familiaridade com a informática, somente consegui acessar programas de conversação a partir do início do ano seguinte. Um mundo novo se abria para mim!

Logo tive contato com canais do IRC (Internet Relay Chat), cujos nomes agrupavam interesses comuns, e passei a acessar canais com temáticas gays. Os comentários mais constantes eram no sentido do alívio das pessoas em poderem abordar o assunto e falar de suas próprias vivências sem discriminação, e de haver um meio de conversar sem se expor.

Com o passar do tempo, os referidos canais passaram a ser ponto de encontro virtual e se constituíram como um meio de contato real posterior. As pessoas - em geral o público masculino - acessavam com um intuito maior de ampliar sua rede de contato social ou simplesmente conseguir sexo de forma mais rápida e objetiva. Desde então, a intermediação de contatos pela internet e, posteriormente, por mídias sociais, chamaram minha atenção como algo efetivo e que se constituiu de maneira concreta dentro da realidade dos relacionamentos homoafetivos.

Ao cursar as disciplinas da pós-graduação, em que foquei na adoção de uma abordagem eminentemente feminista, e pautada nos estudos de gênero, chamou minha atenção as diferenças do machismo em confronto com os feminismos. O fato de vivermos em uma realidade social heteronormativa aumentou meus questionamentos a respeito das diversas formas de relacionamentos e conjugalidades.

Em um momento em que as chamadas relações puras são mais valorizadas, em que a afetividade ganha prioridade em detrimento das tradições, e diante das novas possibilidades de arranjos conjugais contemporâneas, formulei a seguinte questão de pesquisa: Quais diferenças e semelhanças existiriam entre os processos de construção de relações hetero e homoafetivas? E de modo específico surgiu a indagação: Quais seriam as influências de mídias sociais na construção de relacionamentos homoafetivos?

O objetivo geral foi, portanto, compreender usos de mídias sociais/internet na construção de relacionamentos homoafetivos masculinos e femininos. Os objetivos específicos foram identificar elementos de preconceitos que envolvem homoafetividades; verificar em que medida existe visibilidade da experiência relacional/conjugal de membros da comunidade LGBTTT (Lésbicas, Gays, Bissexuais, 
Transexuais, Trangêneros e Travestis) na mídia em geral e em artigos científicos; conhecer a contribuição da virtualidade digital para o início de relações amorosas, principalmente de relações entre homoafetivas/os; apontar diferenças no uso dos meios virtuais entre casais homoafetivos masculinos e femininos.

Ao iniciar a pesquisa, me deparei com pouco material científico nacional disponibilizado em revistas científicas da área da psicologia a respeito de relações iniciadas e/ou constituídas por meio da internet/mídias sociais. O material que envolve relações homoafetivas também se mostrou menor do que eu poderia imaginar, o que levou ao questionamento relativo aos motivos que poderiam envolver essa ausência de representatividade da homoafetividade no meio acadêmico.

Procurei utilizar elementos da teoria feminista na elaboração do trabalho, no sentido de priorizar textos e artigos escritos por mulheres, além de valorizar o uso de palavras e referências femininas na própria elaboração do texto, por considerar que o masculino prepondera socialmente e, em consequência, na própria forma da escrita. Também há elementos da teoria queer, ao apresentar a importância da visibilidade do mundo LGBTTT (Lésbicas, Gays, Bissexuais, Travestis, Transexuais, Trangêneros). Incluí o uso de alguns termos e expressões utilizadas pelas pessoas inseridas nesse grupo social, além de referências aos estudo sobre o combate ao preconceito por orientação sexual e gênero.

Na presente dissertação, o termo mídias sociais é usado para indicar aplicativos e programas que permitem a criação e o compartilhamento de conteúdos gerados por usuários (Kaplan e Haenlein, 2010). Tais instrumentos permitem a troca de informações pelas/os usuárias/os, conforme definições de privacidade que vão desde o nome a ser conferido ao perfil, quanto a demais informações sobre aspectos físicos, preferências, e ainda a inclusão ou não de fotos/filmagens.

O conceito de homoafetividade utilizado é referente ao interesse afetivo e sexual por pessoas do mesmo sexo. O termo é usado em contraponto ao conceito de heterossexualidade, que se define pelo interesse afetivo e sexual por pessoas de sexos diferentes. Várias questões de gênero serão problematizadas nesse contexto.

Essa dissertação está dividida em quatro artigos. O primeiro é um artigo teórico sobre masculinidades e geração de preconceitos. Aborda elementos históricos da homoafetividade masculina e os preconceitos gerados tanto pela sociedade em geral, como dentro da própria comunidade homossexual masculina. Essa comunidade tende a 
repetir a desigualdade de gêneros, quando parte significativa dos gays também desvaloriza homens que tenham características femininas.

O segundo artigo é baseado em pesquisa quantitativa de artigos publicados sobre a homossexualidade e mídias sociais. Aponta questões relacionadas à visibilidade homoafetiva, em termos sociais e em termos acadêmicos. Aborda a produção cultural ou jornalística de diversas mídias a respeito do tema e problematiza e questiona a quantidade de artigos acadêmicos publicados sobre a questão.

O terceiro artigo realiza revisão sistemática de conteúdo de artigos publicados em periódicos brasileiros sobre as formas de contato através da internet e mídias sociais em relações hetero e homoafetivas no Brasil. Apresenta um panorama do uso das mencionadas mídias, com uma descrição da evolução de programas e aplicativos existentes para intermediação do contato virtual e as formas de uso por mulheres e homens.

O quarto artigo apresenta análise de conteúdo de entrevista realizada com quatro casais homoafetivos (dois femininos e dois masculinos), que moram no Distrito Federal e apresenta uma comparação entre as realidades vividas pelos referidos casais. Aborda, portanto, novas formas de conjugalidade e de conceito de família, e relaciona publicações sobre o tema com as respostas trazidas pelas pessoas participantes da pesquisa.

Os estudos aqui desenvolvidos visam contribuir para a produção de conhecimento em uma área importante e ainda negligenciada no campo dos estudos da conjugalidade. Outro objetivo relevante foi contribuir para a prática psicológica no âmbito familiar e conjugal, por entender que a problematização das diferenças sexuais e de gênero deve ser considerada e utilizada em consultório. Por fim, o trabalho visa chamar a atenção para as novas possibilidades de relações afetivas, sejam virtuais ou reais, e para os novos modelos de constituição de família e de realidades por que passam casais da comunidade LGBTTT (Lésbicas, Gays, Bissexuais, Transexuais, Trangêneros e Travestis). As/Os estudiosas/os da área precisam estar atentas/os à necessidade de trabalhos de promoção e prevenção em saúde mental para as pessoas e casais inseridos na mencionada comunidade. 


\title{
ARTIGO I - MASCULINIDADES E GERAÇÃO DE PRECONCEITOS ENTRE HOMOSSEXUAIS MASCULINOS
}

\section{RESUMO}

Tanto as masculinidades como as feminilidades podem gerar preconceitos. Mulheres são vítimas desses preconceitos e também os homens que apresentem algum tipo de característica feminina. Nossa sociedade ainda valoriza mais os atributos masculinos e impõe a heteronormatividade. O que poderia ser considerado uma "subversão" - a homoafetividade - também é marcada por tais influências. Uma parcela considerável do grupo homossexual masculino apresenta preconceitos com relação a estereótipos femininos ou posturas associadas ao feminino.

Palavras Chave: Masculinidades; Homossexualidade; Preconceito; Feminilidade; Estereótipos.

\begin{abstract}
Masculinities and femininities can generate prejudices. Women as well as men are object of such prejudices, specially men who show some kind of feminine characteristics. Our society still places more value on masculine attributes and imposes heteronormativity. What could be considered a "subversion" - the homosexuality - is also marked by such influences. A considerable number of homosexual males show prejudices regarding stereotypes or attitudes associated with women.
\end{abstract}

Keywords: Masculinity; Homosexuality; Prejudice; Feminility; Stereotypes.

\section{Masculino versus Feminino}

"Homem não chora nem por dor nem por amor!" (início da música Homem não chora - Frejat). Em que pese a ironia que permeia toda a música, indiscutivelmente um dos atributos conferidos ao "macho" é não mostrar fraqueza, que seria uma característica associada ao feminino. O homem deve se mostrar forte, dominador, racional. Elisabeth Badinter, com muita propriedade, afirma que "o homem se diz mais no imperativo do que no indicativo" (1993, p. 3).

A ideia da racionalidade como atributo masculino está entranhada no imaginário social há muito tempo. Os filósofos estóicos, na Grécia antiga, a buscavam acima de tudo. A racionalidade é o processo que se contraporia aos conceitos de paixão e amor. Conceitos esses que foram atribuídos, com o passar dos tempos, em nosso mundo 
ocidental, às mulheres. Terá sido coincidência que a raiz "pathos" tenha dado origem tanto à palavra paixão como ao termo patologia?

A masculinidade, em boa parte da cultura ocidental, é universal, no sentido de ser a referência, o padrão, a identidade hegemônica (Badinter, 1993; Connell \& Messerschmidt, 2013; Toneli, 2007). Homem é o que "tem"! Desde Freud, o homem tem o pênis e a mulher a sua inveja. $\mathrm{O}$ homem adquire a propriedade, o pátrio poder cujo conceito somente saiu da legislação brasileira em 2001. Ademais, é ele quem é considerado socialmente como o "chefe da família", o "cabeça do casal".

Friedrich Engels (2006), co-autor do manifesto comunista, ao abordar, em 1884, "A origem da família, propriedade privada e o Estado", explica que o significado original da palavra "família" teria vindo de "famulus", ou escravos domésticos. Ou seja, a família era considerada como o número total de escravos domésticos pertencentes a um homem. Posteriormente, a mulher e os filhos vieram também a fazer parte desse grupo.

A hierarquia masculina prevaleceu no mundo eurocêntrico. Seus desdobramentos se tornaram evidentes e notórios no processo de colonização do Brasil . Uma breve análise empírica, com conhecidos, notícias de jornais ou televisão ou no âmbito de nossa própria família pode revelar a cada um/a de nós inúmeros exemplos da dominação masculina extremamente presente nos dias de hoje. Presente, frequente e, por várias vezes, imperceptível para quem senta na cabeceira da mesa. "Nossos privilégios são com frequência invisíveis para nós" (Badinter, 1993, p. 10).

Um breve experimento pode ser adotado para trazer à tona a referida universalização e preponderância do masculino. Pense em cientistas, protagonistas de histórias, pessoas de destaque social ou econômico, nos líderes mundiais. A presença de mulheres nesse grupo ainda constitui a exceção e não a regra.

Outro exemplo da supremacia do masculino se faz presente em nossa língua portuguesa. Se há plural envolvendo palavras masculinas e femininas, qual gênero deve prevalecer como referência? Amanda Oliveira Rabelo (2010) defende que devemos realizar uma revisão constante em nosso vocabulário, de forma que deixemos para trás a concepção do masculino como positivo, função genérica, norma, e o feminino como negativo, exceção à norma. O binarismo permeia a valorização e diferenciação de gênero, na vida e na linguagem (Baccheta, 2009).

Não é a toa que o xingamento mais ofensivo no caso dos homens costuma ser "veado", pois aponta para uma proximidade ao feminino, a que o homem seja uma 
"mulherzinha", atingindo a noção de virilidade masculina, que deve ser eternamente provada, quando "o feminino é relacionado à falta, falha, falência e vulnerabilidade" (Zanello \& Gomes, 2010, p. 270).

O feminino é o contraponto. O que sai do padrão. Não só nos aspectos sociais, como nos políticos e científicos, dentre outras dimensões da vida. Ainda se fazem presentes concepções no sentido de que uma boa gestora ou líder deve apresentar características atribuídas ao masculino, como racionalidade e equilíbrio. Essa pessoa deve ser enfática, diretiva, dura, potente.

Mesmo na vida doméstica e familiar, a mãe deve ser firme e coerente. Caso contrário, será passível de ser "portadora de patologias", como depressão, histeria, ou pior, causar distúrbios nos filhos. Nesse contexto ela passa a ser nomeada como mãe esquizofrenizante, e/ou superprotetora. A própria ciência psicológica é, portanto, generificada.

Por um lado, o homem continua sua dominação, permanece no topo da cadeia produtiva, mais valorizado economicamente e socialmente que a mulher. Mas por outro, os movimentos sociais que surgiram no período pós-guerras geraram questionamentos relativos ao "masculino" e "feminino" e abriram portas para outras questões de gênero, como a homossexualidade.

O fato é que, apesar das novas reflexões trazidas contemporaneamente, o homem que ao invés de "progredir" e buscar "ascensão", no sentido de perpetuar sua dominação, "cairá" na estrutura social ao apresentar qualidades ou características femininas. O homem que busca outros padrões de exercício da sexualidade e de vivência da conjugalidade é desvalorizado. É importante para a psicologia e para a academia problematizar o lugar social ocupado por esse homem.

\section{Homossexualidade masculina e elementos históricos do preconceito}

Ainda hoje, há quem discuta se a homossexualidade seria crime, safadeza ou doença. O discurso (não tão antigo) de médicos, juristas, psiquiatras e peritos criminais versava sobre a etiologia e a capacitação para a cura da condição homoafetiva. Havia uma lógica, principalmente religiosa, para tal postura: relações homossexuais não geram filhos, o grande dom concedido às famílias e o propósito final das relações sexuais. 
A esterilidade implicaria no "comprometimento da viabilidade demográfica e do poderio étnico e religioso da tribo, sendo representada em termos religiosos como castigo" (Rodrigues, 2012, p. 367). A autora mostra que, com a crise demográfica havida na Idade Média, em virtude do elevado número de óbitos ocasionado pelas pestes, as práticas sexuais não procriativas e contraceptivas passaram a ter uma ampla proibição.

A percepção da pessoa homossexual como diferente e marginalizada pela sociedade (e não simplesmente da prática em si) viria, efetivamente, por volta do ano 1.700 (Araújo, 2005). A mudança de postura surgiria algum tempo depois do Renascimento, quando teria havido uma "generalização da ideia de que todos os homens que faziam sexo com homens eram afeminados e todas as mulheres que desejavam outras mulheres eram masculinizadas e agressivas" (Araújo, 2005, p. 25).

No Brasil, fala-se pouco a respeito de tais práticas no início da colonização. Contudo, Mott (2008) cita a carta enviada pelo padre Jesuíta Pero Correia de São Vicente, no litoral paulista, ao Superior da Companhia de Lisboa, em 1551, dando visibilidade às práticas homoafetivas da época. $\mathrm{O}$ autor prossegue, afirmando que se não fosse a visitação do Santo Ofício e documentação apresentada pela inquisição em sua atuação no Brasil, pouco saberíamos das práticas sexuais entre os homossexuais.

Os relatos apresentados por Mott (2008) demonstram o grau de detalhes em termos de práticas sexuais. Tais relatos têm valor histórico, dentre outros fatores por revelar suas nomeações e a classificação de seus agentes, vistos e nomeados de formas pejorativas, como fanchonos, tibiras explícitos, sodomitas encobertos etc.

Outros detentores do poder - médicos, psiquiatras, tais como os eclesiásticos - ao também classificar o que seriam os diagnósticos, personificaram as práticas e criaram as personagens, nomes, classificações ou heresias. Por outro lado, tais agentes, ao classificar e tipificar as referidas práticas, também lhes teriam dado visibilidade, atraído curiosidade e uma certa publicidade (Foucault, 1988).

Giddens (1993) discorda desse posicionamento, ao ressaltar que o acesso aos textos médicos era restrito a um público muito limitado. $\mathrm{O}$ autor considera, ainda, o fato da maioria da população ser analfabeta até a última parte do século XIX. Sua posição é no sentido de que as questões sexuais foram expostas e debatidas de forma mais efetiva com o surgimento de métodos contraceptivos mais eficazes, a partir da década de 1960.

Os métodos contraceptivos permitiram a realização de sexo sem a preocupação constante da concepção e, consequentemente, ampliaram significativamente seu 
exercício pelo prazer (Giddens, 1993). A sexualidade se dissocia da necessidade de procriação e construção de uma família, caracterizando-se como uma propriedade individual (Neckel, 2007).

O desligamento entre sexualidade e procriação, a princípio, não parece guardar relação com as discussões atinentes à homossexualidade. Esse processo traz, no entanto, um encadeamento lógico. Se o sexo pode ser realizado por puro prazer, as relações sexuais homossexuais passariam a ser cogitadas como uma possibilidade mais efetiva, e em termos de uma suposta "aceitação", mas tal aceitação se daria de forma velada.

Outro impacto importante desse desligamento foi o fato dos vínculos não serem mais criados e mantidos precipuamente em virtude de interesses econômicos, procriação ou para manter nomes e tradições familiares. A afetividade passou a guiar as uniões conjugais, e provocou uma reformulação nos conceitos de família (Giddens, 2011; Castañeda, 2007).

Vale ressaltar, contudo, que a discordância entre Giddens e Foucault é provocativa. Certamente este último não estava completamente equivocado. Principalmente se trouxermos seu pensamento para os dias de hoje, no que diz respeito à AIDS e campanhas de prevenção, ou a decisões judiciais e discussões no Congresso Nacional, que suscitam amplos debates na sociedade.

Pouco antes da proliferação e do conhecimento da AIDS, suas características e efeitos, no início dos anos 1980, a homossexualidade era associada a uma alternativa combativa à sexualidade padrão da sociedade patriarcal e heterossexual (Arán, 2004). Por um lado, havia uma conivência daqueles e daquelas que procuravam discutir as normatividades existentes, e por outro, a moral vigente e dominante sugeria que o homossexual poderia ser aceito, contanto que celibatário ou, na pior das hipóteses, de forma marginal.

Não é sem razão que os temas da homossexualidade e da homoafetividade, por muitas vezes, sejam tratados como tabu ou caracterizados como um segredo no âmbito familiar. O medo é que sua revelação pode ser prejudicial não só para aquele que se percebe e se identifica como homossexual, como também para sua família, caso seja fator limitador de conversas em muitas áreas ou contextos. Essa necessidade de encobertar a presença da homossexualidade de um ou mais de seus membros acaba restringindo a capacidade da família para solucionar problemas e conflitos, além de muitas vezes, gerar sintomas os mais diversos, numa perspectiva sistêmica (ImberBlack, 2002). 
Sanders (2002) afirma que "inexiste uma experiência de vida mais tiranizada pelo segredo do que a de ser gay ou lésbica" (p. 223). A pessoa deve escolher entre a autoafirmação ou a autoanulação, caso haja conformismo à sociedade. Caso opte pela autoafirmação, provavelmente sofrerá em função da presença de algum tipo de homofobia, direta e pessoal, e também indireta, através de piadas e desvalorização/desqualificação de homossexuais. Ademais, a pessoa será objeto de preconceito por parte de instituições sociais que privilegiem discursos heteronormativos.

A Secretaria de Direitos Humanos da Presidência da República apresentou, em 2013, a segunda versão do Relatório sobre a Violência Homofóbica no Brasil. A primeira versão foi realizada em 2012, referente ao ano anterior, e os dados são significativos.

Nacionalmente, foram $71,38 \%$ de vítimas do sexo masculino e $20,15 \%$ do sexo feminino. A maior parte de vítimas concentra-se na população jovem, com $61,16 \%$ de vítimas entre 15 e 29 anos. Nos dados, também aparece a questão de cor/raça, os negros (pretos e pardos) totalizam mais da metade do grupo que sofre violência.

A exposição, portanto, não depende só da possibilidade de auto-aceitação e de eventual aceitação externa. A possibilidade de manifestar abertamente a homossexualidade e a homoafetividade é pautada por uma questão premente em termos do preconceito e do medo de violência sofrida. Frequentar lugares "amigáveis" pode, portanto, não significar o estigma do gueto, mas indicar a necessidade de pertencimento e de proteção.

Verifica-se que há uma vantagem em termos de evitação do preconceito no que se refere ao homossexual masculino não afeminado. Ele escolhe se vai se expor ou não, se vai apresentar, tornar pública sua orientação sexual e assumir os riscos a ela inerentes, ou se prefere manter sua vida sexual em segredo. Ele pode ter uma experiência diferente daquela de mulheres, negros, portadores de necessidades especiais, dentre outros, que fisicamente estampam suas características e delas não podem se esconder.

A transição que pode ser saudável para aqueles que não desejam se expor ou sair do armário é a passagem do segredo para a privacidade, em que as/os homossexuais escolhem aquelas/es para quem se exporão, de modo a garantir sua socialização, aceitação e sensação de pertencimento a determinado grupo (Sanders, 2002). Desse modo podem deixar outras pessoas à margem da situação, pessoas estas que poderiam, 
eventualmente, causar algum prejuízo pessoal ou profissional, em virtude do preconceito.

Naturalmente, e em virtude dos preconceitos explícitos e implícitos, as/os homossexuais se agrupam e criam uma noção de coletividade através de locais que os aceitem e respeitem (Araújo, 2005, p. 27). O surgimento da internet comercial no Brasil na década de 1990, e posteriormente de outros meios de comunicação via telefonia móvel permitiu que o pertencimento a uma coletividade ocorra tanto na "vida real", como na virtualidade.

Tal coletividade, no entanto, não é padronizada. Há grupos específicos, interesses diferenciados, estilos de moda e comportamento, que indicam influências diversas. Inclusive, é importante destacar que existe uma força e presença de visões machistas e heteronormativas dentro do próprio grupo homossexual.

\section{O preconceito entre os homoafetivos - aspectos de masculinidades}

O estereótipo masculino é valorizado e incentivado desde a mais tenra idade, quando se trata de meninos. Há uma preocupação explícita dos pais, familiares, amigos e conhecidos com relação ao modelo masculino. Assim que o sexo é descoberto, as expectativas são construídas e a cor do quarto é definida, a decoração é pensada com referências específicas ao sexo.

Os meninos, ainda na gestação, já têm seus pênis mencionados como maiores que o esperado, e costumam ser mais festejados pelos pais, que iniciam a construção do padrão dominante heteronormativo, mesmo distante da data do nascimento. De preferência, o filho será o garanhão, o bonitão, o extrovertido, o esportista, o levado, o inteligente, o bem sucedido, enfim, o orgulho do pai.

No processo de desenvolvimento dos meninos, até é possível se conceber uma fase em que existiria uma pedagogia homossexual (Badinter, 1993), como um sistema de passagem, de desenvolvimento do infantil ao adulto. Inicialmente, é aceitável o contato exclusivo com amigos da mesma idade, dependendo da fase de desenvolvimento. Há certas iniciações realizadas pelos mais velhos, de forma a permitir sua inserção no grupo social a que pretenda pertencer, geralmente que envolvem dominação e uma obediência posterior ao padrão masculino heteronormativo. 
Tais iniciações não são novidade. Remontam, ao menos, à época grega, em que os filósofos iniciavam seus pupilos, transmitiam seus conhecimentos. Todavia, mesmo àquela época, e em outras culturas, as iniciações que envolviam os meninos tratavam-se de um momento, fase, uma transição, um caminho para a heterossexualidade.

A submissão à heterossexualidade é, portanto, a oportunidade para a entrada no universo masculino. Significa a inserção no grupo, a conquista de uma posição. "O masculino é, ao mesmo tempo, submissão ao modelo e obtenção de privilégios do modelo" (Welzer-Lang, 2001, p. 464).

O que não se permite é ficar no meio do caminho, "fixado" na homossexualidade, em algo que seria apenas uma fase do desenvolvimento. E não basta ser heterossexual - a masculinidade é pautada pela necessidade de ter/assumir o estereótipo heterossexual normativo. "Para ser um (verdadeiro) homem, eles devem combater os aspectos que poderiam fazê-los serem associados às mulheres" (WelzerLang, 2001, p. 462).

O homem, em geral, para ser considerado bonito, deve se opor ao feminino. Deve ter "cara de homem e não de molequinho" e deve "transmitir masculinidade". A pele deve ser "boa", mas não pode ser bonitinha, feito bundinha de bebê. O rosto não pode transmitir "cara de veadinho", "cara de bonzinho", "cara de mauricinho", “cara de criancinha”, "cara de novinho" (Fontes, O. A., Borelli, F. C., Casotti, L. M., 2012, p. 416).

O homem, portanto, deve parecer e se portar como homem. Deve guardar distância do feminino, que é subvalorizado socialmente (Miskolci, 2011; Silva, T.C.M., Amazonas, M.C.L.A. \& Vieira, L.L.F., 2010). Caso contrário, estará fadado a sofrer discriminações pautadas pelo gênero (Rabelo, 2010).

Certamente, tais questões dependem de época, localidade, classe social, como demonstra Badinter (1993), ao falar dos preciosos na França (com características mais femininas), em contraponto com os homens da Inglaterra, que relacionavam a masculinidade ao tradicional e ao patriotismo. É patente que ainda há grande preponderância dos elementos associados ao estereótipo masculino como fator identitário, não só para o grupo heterossexual, mas também em grupos específicos de homossexuais.

O momento atual tem uma marca paradoxal. Não é mais possível falar na existência de um bloco hegemônico das masculinidades, seja hétero ou homossexual. Apesar de homens heterossexuais poderem cada vez mais se apropriar de aspectos das 
masculinidades gays (veja a questão dos metrossexuais), tampouco existe uma efetiva "hibridização". Ainda estamos longe de uma confluência dessas masculinidades (Demetriou, 2001, citado por Connell, 2013).

A presença de atributos femininos no homem, em nossa cultura nacional, é criticada, ironizada ou, ainda, considerada como identificação homossexual. Para algumas pessoas, o homossexual masculino é alguém que nasceu com uma doença que o torna, necessariamente, afeminado. Caso contrário, é considerado um pervertido.

Há alguns anos atrás, em um ambiente militar, pude presenciar uma conversa e constatar a força de tal percepção. Dois oficiais das forças armadas conversavam e expunham suas perspectivas a respeito da homossexualidade masculina. Na opinião de um dos interlocutores, o problema não era ser "veado", porque alguns teriam uma doença mesmo, o que daria para perceber nos seus trejeitos, por serem afeminados. Não poderiam ser aceitos, contudo, aqueles que têm postura de homem, mas praticam sexo com outros homens por pura safadeza. Absurdo!

O fato é que os modelos de comportamento para ambos os sexos são socialmente impostos, e tratados como se fossem naturais (Rabelo, 2010). Queiroz (2008), em sua dissertação de mestrado realizada em Brasília, informa que:

“a matriz heterossexual é tão introjetada que até os próprios homossexuais consideram que a sociedade tem o direito de censurá-los ou mesmo puni-los por não se conformarem às regras dominantes ou não se restringirem aos seus espaços" (p. 103).

As interdições sociais deixam marcas. Determinada parcela de homossexuais masculinos acredita que não se deve demonstrar carinho ou sentimentos amorosos por parceiros, companheiros em público, a não ser em determinados lugares próprios, destinados aos grupos LGBTTT (Lésbicas, Gays, Bissexuais, Travestis, Transexuais e Trangêneros). Todavia, mesmo tais lugares seriam diferenciados. Em Brasília, "frequentadores do Beirute e do Café Savana estariam mais perto de um padrão definido do que o do Barulho" (Rabelo, 2010, p. 105).

Explica-se: Beirute e Café Savana são locais mais elitizados, apesar de haver mais diversidade no Beirute, restaurante com temática árabe, bar e ponto de encontro referência desde os primórdios da cidade, com público composto por jornalistas, intelectuais, professores e, com o passar do tempo, homossexuais, em noites de fim de semana. Já o Barulho, bar localizado dentro do Parque da Cidade, apresenta público LGBTTT bem mais eclético, mas também restrito às noites de fim de semana. 
Há uma diferença de público bem perceptível nos referidos lugares. O Barulho congrega classes econômicas diferenciadas, muitos dos frequentadores vão de ônibus, há maior permissividade para presença de travestis e homossexuais que saiam de um "padrão" de homonormatividade. As formas de se expor, agir e vestir são bem mais diversificadas.

Os homossexuais também se segregam, criam "guetos" voltados para suas afinidades e interesses. Seja para formar um sentimento de grupo, paquerar, demonstrar carinho por seu par ou poder sair do estereótipo imposto socialmente. Existe, contudo, uma gradação, espaços mais ou menos democráticos e padronizações em maior ou menor grau no que se refere ao estereótipo feminino do homem homossexual. Um dos depoimentos apresentados por Queiroz (2008) em sua dissertação, confirma o pensamento de muitos homossexuais masculinos: "eu não gosto de gente afetada. Acho que não tem necessidade de você ser afetado" (p. 99).

Não é raro ouvir de homossexuais: "ora, se fosse para ficar com alguém afeminado, seria melhor ficar com mulher”. É notório, portanto, que existe uma desvalorização no que se refere ao homem afeminado, o homem que apresenta características femininas e, paradoxalmente, mesmo que inserido em determinados grupos homossexuais.

A companhia de comédia "Deznecessários" brinca com a questão da masculinidade na paródia "Traficante Viado", disponível no youtube. O traficante demonstra todo estereótipo de macho, mas relata a forma que gosta de ser dominado ou de ser passivo no ato sexual. Não é a toa que a situação se torna irônica, ao refletirmos sobre a estranheza que causa no imaginário social.

Nos ambientes virtuais também pode ser verificado o dissenso de posturas. Existe um grupo que busca se destacar, procurando parceiros não afeminados ou considerados "fora do meio". Miskolsi (2013) realizou uma pesquisa em salas de bate papo virtuais de São Paulo, e afirmou ser comum que muitos se apresentem como "machos", "discretos", que buscam parceiros sexuais que possam circular no espaço público como se fossem amigos. Nesse contexto, Miskolsi (2013) afirma que:

"A experiência de sair e paquerar mulheres para "provar" sua aparente heterossexualidade torna esses homens mais atraentes para seus parceiros em uma dinâmica aparentemente paradoxal, mas esclarecedora sobre o tipo de desejo erótico que a molda" (p. 309). 
Esse comportamento ocorre como contraponto, para demarcar a aversão aos "afeminados", "veados", "bichinhas afetadas", "com voz de pato", Esses homens buscam em si mesmos e em sua escolha de parceiros afirmar uma masculinidade pretensamente heterossexual.

O estereótipo de "macho" continua, portanto, sendo valorizado em uma parcela significativa de um grupo que, teoricamente, seria "subversivo", mas que repete os ditames da heternormatividade (Paiva, 2009). Essa discussão se aprofunda ainda mais quando levantamos a questão da posição sexual.

Da mesma forma que o estereótipo do macho é buscado em boa parcela do público homossexual masculino, há uma disputa de "dominação" ao se abordar as preferências no que se refere à penetração anal. Muitas vezes, o passivo é visto com menosprezo.

Tal visão não é recente. Desde os romanos já havia provocações com relação aos homens que se submetiam à penetração passiva, apesar da permissão social para o coito homossexual (Rodrigues, 2012). A "atividade" em termos sexuais era vinculada à dominação e valores positivos, enquanto a posição "passiva", dominada era vista como inferior (Foucault, 1988).

O dominante, ativo, é melhor e socialmente aceito, enquanto o dominado, passivo, é considerado o "verdadeiro veado", o que se deixa penetrar (Welzer-Lang, 2001). Alguns homens, considerados “garanhões", "comedores", não se importam de ter relações sexuais com outros homens, contanto que sejam ativos na penetração e não haja demonstração de carinho ou beijo na boca.

Claro que há preferências que não se referem necessariamente à dominação. Existem homens que não suportam a dor referente à penetração, não conseguem relaxar ou somente admitem ser penetrados quando o parceiro é menos dotado em termos de tamanho do pênis. Estas são, entretanto, especificidades que não fazem parte da presente discussão. O que está sendo problematizado aqui é a não aceitação e/ou submissão a uma posição sexual pautada por critérios heteronormativos.

A vinculação, no imaginário social, entre o homem sexualmente passivo e características femininas é tão forte, que é comum se atribuir ao homem mais afeminado a posição passiva na relação sexual. Num rápido olhar já se define quem é o ativo e quem é o passivo em virtude de estereótipos apresentados pela dupla. Certamente, o mais másculo, o mais "homem" seria o que come, e o mais frágil ou que apresente aspectos femininos seria o que dá. 
Fica evidente que os parâmetros hegemônicos que pautam a vivência da experiência sexual são muito fortes e adentram a comunidade homoafetiva. Por mais que consideremos as especificidades sexuais, as inúmeras possibilidades de manifestação e de exercício da sexualidade, ainda são repetidos os mesmos padrões tão antigos e entranhados socialmente. $\mathrm{O}$ masculino domina, o feminino é dominado. $\mathrm{O}$ masculino penetra, o feminino é penetrado. O masculino submete e se impõe, o feminino é submetido.

Questões de gênero e sexualidade possuem inegável força cultural e pressão social. O que foge aos padrões heternormativos estabelecidos é, no mínimo, criticado, quando não descriminado ou relegado à invisibilidade. O que espanta, todavia, é o fato de tais padrões serem utilizados no âmbito da própria comunidade homossexual.

\section{Respeito às diferenças}

As masculinidades são construídas! Notadamente, há um esforço dos homens para permanecerem na posição de dominantes, marcado pela busca de justificativas "naturais", evolutivas, tais como a ideia de que o macho precisava sair para caçar, ser predominante em força e agressividade para conseguir as fêmeas, etc. Nos dias atuais, essa lógica se atualiza para justificar a manutenção da "família tradicional", visando à proteção das bases da sociedade ou a preservação dos valores cristãos.

Ao trazermos reflexões acerca de tais concepções hegemônicas para a realidade homossexual, alguns questionamentos imanentes às masculinidades e às suas construções permanecem. Nesse contexto, surgem várias questões:

1. Seria ingenuidade buscar um conceito de masculinidade homossexual hegemônica?

2. Os preconceitos inerentes à construção de tais masculinidades não deveriam ser extremamente minorados no meio homossexual?

3. Por que o estereótipo feminino em homens gays é criticado e, por vezes, combatido também de forma intragrupal no meio homossexual masculino?

4. Questões relativas ao ser dominante/dominado, ativo/passivo permaneceriam relevantes no exercício de posições sexuais atuadas por homens homossexuais? 
A intenção não é dar respostas a esses questionamentos, mas apontar que a dominação suplanta a questão homem/mulher, e se mostra como uma dominação intramasculina (Badinter, 1993), não só no meio heterossexual, mas também no meio homossexual. Da mesma forma que o homem predomina nos melhores postos de trabalho, enquanto trabalhos "menos valorizados" são destinados às mulheres, o homossexual assumido ou que tenha aspectos afeminados continua sendo, de forma efetiva ou no imaginário social, também vinculado a certas profissões que não são consideradas "masculinas" ou "dignas" de ser exercida por boa parte dos homens - tais como visagista, estilista, decorador.

O sucesso de alguns cabelereiros, costureiros, designers, artistas mostra ser possível sair até certo ponto do padrão, mas a força do patriarcado e da heteronormatividade ainda se impõe em diversos grupos de homossexuais. Socialmente é aceito que homossexuais masculinos estejam mais abaixo em uma pirâmide de valorização social, mas não descer tanto de forma a ser comparado às mulheres.

Caso considerarmos certa ou aproximada a previsão de que $10 \%$ da população ocidental seja constituída predominantemente de praticantes do homoerotismo, segundo o relatório Kinsey (Mott, 2006), fica notório que há pouca visibilidade dos homossexuais. Certamente, tal fato se deve em parte a uma necessidade de autopreservação, como ao medo de ser objeto de preconceito e discriminação social aqueles que não saem do armário (Sedgwick, 2007), mas por outro lado, está relacionada também ao autopreconceito inerente ao lidar e assumir aspectos de si mesmo.

Acredito que "libertação" desse constante esforço em ser masculino, dessa imperatividade da heteronormatividade, passa pela valorização da mulher, do feminino e desconstrução de uma hierarquia entranhada nos pensamentos de cada um/a de nós individualmente, e em nossa sociedade eurocêntrica. Homens e mulheres são diferentes, sejam heterossexuais e homossexuais, transexuais, trangêneros, travestis e todas as pessoas que exercem as várias formas de expressão de gênero ou sexualidade e tais diferenças devem ser respeitadas.

$\mathrm{O}$ respeito e a valorização das diferenças, que permita o acolhimento do humano, do ser vivo, como detentor de direitos e deveres dentro da sociedade, mediante a livre expressão de suas características é um passo ainda largo a ser adotado. O desafio, contudo, vale o esforço pela desconstrução de estereótipos e a busca pela efetividade do tratamento isonômico de todas e todos. 
Há necessidade, portanto, de aprofundamento dos estudos no que se refere às diferenças sexuais e de gênero, além de ações políticas efetivas. Tais diferenças foram elaboradas socialmente e, portanto, são passíveis de ser desconstruídas. Essa tarefa cabe a todos e a cada um/a de nós, seja pela atuação em políticas públicas ou através de atuação no campo da educação, por meio de presença nas escolas, discussões acadêmicas, pela realização de pesquisas e produções de artigos. E, por que não, conversas com as pessoas que nos cercam e estejam disponíveis para refletir sobre algo diferente? Este trabalho assume esse tipo de compromisso. 


\section{REFERÊNCIAS}

Arán, M. \& Correa, M. V. (2004). Sexualidade e política na cultura contemporânea: o reconhecimento social e jurídico do casal homossexual. Physis, Rio de Janeiro, v. 14, n. 2, July 2004. Recuperado em 11 de dezembro de 2012, de http://www.scielo.br/scielo.php?script=sci_arttext\&pid=S0103$73312004000200008 \& \operatorname{lng}=e n \& n r m=i s o$;

Araújo, M. M. X. (2005). Homossexualismo: do preconceito à aceitação. In Contextos Familiares. Associação Gaúcha de Terapia Familiar - AGATEF, ano 2, n. 2, 2005;

Badinter, E. (1993). XY Sobre a identidade masculina. (Trad. Maria Ignez Duque Estrada). Nova Fronteira, Rio de Janeiro, 1993;

Baccheta, P. (2009). Co-formações / co-produções: considerações sobre poder, sujeitos subalternos, movimentos sociais e resistência. In Leituras de Resistência: corpo, violência e poder. Vol. 1, Org. Carmen Susana Tornquist et all. Editora Mulheres.

Brasil, Secretaria de Direitos Humanos do Governo Federal (2013). Relatório sobre a Violência Homofóbica no Brasil. Recuperado em 21 de maio de 2014, de http://www.sdh.gov.br/noticias/2013/junho/numero-de-denuncias-de-violenciahomofobica-cresceu-166-em-2012-diz-relatorio;

Castañeda, M. (2007). A experiência homossexual - explicações e conselhos para os homossexuais, suas famílias e seus terapeutas. Tradução de Brigitte Monique Hervot e Fernando Silva Teixeira Filho. $1^{\text {a }}$ Edição. A Girafa Editora;

Connell, R. W. \& Messerschmidt, J. W. (2013). Masculinidade hegemônica: repensando o conceito. Revista de Estudos Feministas, Florianópolis, v. 21, n. 1, Abr. 2013. $\begin{array}{lllll}\text { Recuperado em } 24 \text { de novembro } & \text { de 2013, }\end{array}$ http://www.scielo.br/scielo.php?script=sci_arttext\&pid=S0104026X2013000100014\&lng=en\&nrm=iso;

Deznecessários. Traficante viado. Recuperado em 24 de novembro de 2013, de http://www.youtube.com/watch?v=AvvEPCoPD9c;

Engels, F. (2006). A origem da família, da propriedade privada e do Estado. Tradução

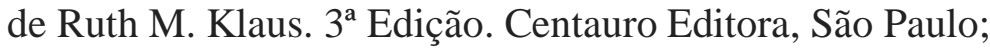

Fontes, O. A., Borelli, F. C., Casotti, L. M. (2012). Como ser homem e ser belo? Um estudo exploratório sobre a relação entre masculinidade e o consumo de beleza. REAd. Rev. eletrôn. adm. (Porto Alegre), Porto Alegre, v. 18, n. 2, Ag. 2012. Recuperado em 20 de outubro de 2013, de http://www.scielo.br/scielo.php?script=sci_arttext\&pid=S1413$23112012000200005 \& \operatorname{lng}=\mathrm{en} \& \mathrm{nrm}=\mathrm{iso}$;

Foucault, M. (1988). História da Sexualidade I: A vontade de saber. Trad. Maria Thereza da Costa Albuquerque e J. A. Guilhon Albuquerque. Graal, Rio de Janeiro, 176 $\mathrm{p}$ 
Giddens, A. (1993). A transformação da intimidade: sexualidade, amor e erotismo nas sociedades modernas. Trad. Magda Lopes, Unesp. São Paulo, 228 p;

Giddens, A (2011). Mundo em descontrole: o que a globalização está fazendo de nós. Trad. Maria Luiza X. de A Borges. 4. Ed. Rio de Janeiro, 107p;

Mello, L. (2005). Outras famílias: a construção social da conjugalidade homossexual no Brasil. Cadernos Pagu, Campinas, n. 24, Junho 2005. Recuperado em 11 de junho de 2012, de http://www.scielo.br/scielo.php?script=sci_arttext\&pid=S0104$83332005000100010 \& \operatorname{lng}=\mathrm{en} \& \mathrm{nrm}=\mathrm{iso}$;

Miskolci, R. (2011). O desejo da nação: Raul Pompéia e a gramática do desvio no Brasil finissecular. In Fronteiras de Gênero. Org. Joana Maria Pedro, Silvia Maria Fávero Arend, Carmen Silvia de Moraes Rial. Editora Mulheres.

Mott, L. (2006). Homo-afetividade e direitos humanos. Revista de Estudos Feministas, Florianópolis, v. 14, n. 2, Set. 2006. Recuperado em 19 Dez. 2012, de http://www.scielo.br/scielo.php?script=sci_arttext\&pid=S0104-

026X2006000200011\&lng=en\&nrm=iso;

Mott, L. (2008). Pré-história da homossexualidade em São Paulo: 1532-1895. DIALOGUS - Revista das Graduações em Licenciatura em História e Geografia. V.4, n.1. 2008. Recuperado em 18 de dezembro de 2013, de http://baraodemaua.br/comunicacao/publicacoes/dialogus/2008/pagina3.html;

Neckel, R. (2007). A “ciência sexual” e os "guias" do "casal moderno". In Leituras em rede: gênero e preconceito. Org. Cristina Scheibe Wolff, Marlene de Fáveri, Tânia Regina Oliveira Ramos. Editora Mulheres.

Paiva, A. C. S. (2009). Miséria de posição e laço social nas homossexualidades. In Leituras em rede: gênero e preconceito. Org. Cristina Scheibe Wolff, Marlene de Fáveri, Tânia Regina Oliveira Ramos. Editora Mulheres.

Queiroz, C. M. (2008). Estigmas, guetos e gentrificação: a segregação homossexual em Brasília. 119 f. 2008. Dissertação (Mestrado em Sociologia)-Universidade de Brasília, Brasília, 2008;

Rabelo, A. O. (2010). Contribuições dos Estudos de Género às Investigações que Enfocam a Masculinidade. Ex aequo, Vila Franca de Xira, n. 21, 2010. Recuperado em 20 de outubro de 2013, http://www.scielo.gpeari.mctes.pt/scielo.php?script=sci_arttext\&pid=S0874$55602010000100012 \& \operatorname{lng}=$ pt\&nrm=iso;

Rodrigues, R. C. C. (2012). Homofilia e homossexualidades: recepções culturais e permanências. História Franca, v. 31, n. 1, Junho 2012. Recuperado em 15 de dezembro de 2012, de http://www.scielo.br/scielo.php?script=sci_arttext\&pid=S010190742012000100018\&lng=en\&nrm=iso; 
Sanders, G. L. (2002). O amor que ousa declarar seu nome: do segredo à revelação nas afiliações de gays e lésbicas. In: Os segredos na Família e na Terapia Familiar: Artmed, 420 ;

Sedgwick, E. K. (2007) A epistemologia do armário. Cadernos Pagu (28), janeirojunho de 2007:19:54;

Silva, T.C.M., Amazonas, M.C.L.A. \& Vieira, L.L.F. (2010). Família, Trabalho, identidades de gênero. Psicologia em Estudo, 15(1), 151-159. Recuperado em 20 de novembro de 2014, de http://www.scielo.br/scielo.php?script=sci_arttex\&pid=S141373722010000100016\&Ing=en\&tlng=pt.10.1590/S1413-73722010000100016;

Toneli, M. J. F. (2007). Diversidade Sexual Humana. In Leituras em rede: gênero e preconceito. Org. Cristina Scheibe Wolff, Marlene de Fáveri, Tânia Regina Oliveira Ramos. Editora Mulheres.

Welzer-Lang, D. (2001). A construção do masculino: dominação das mulheres e homofobia. Revista de Estudos Feministas, Florianópolis, v. 9, n. 2, 2001. Recuperado em 20 de outubro de 2013, de http://www.scielo.br/scielo.php?script=sci_arttext\&pid=S0104026X2001000200008\&lng=en\&nrm=iso;

Zanello, V. \& Gomes, T. (2011). Xingamentos masculinos: a falência da virilidade e da produtividade. Caderno Espaço Feminino, v. 23, n. 1/2. 


\title{
ARTIGO II - DESAQUENDA DE NÁRNIA - ASPECTOS DA (IN)VISIBILIDADE HOMOSSEXUAL
}

\section{RESUMO}

Este trabalho apresenta reflexões a respeito da (in)visibilidade da homossexualidade, e em especial de relações homoafetivas. Problematiza a questão, e mostra dimensões do preconceito que a cerca. Em seguida, apresenta pesquisa sobre publicações científicas a respeito do tema com recorte quantitativo. A produção científica em periódicos brasileiros e internacionais ainda é pequena. Conclui-se que dar visibilidade a homoafetividade pode servir como elemento propagador de referências positivas para a sociedade de modo a desmistificar esses preconceitos.

Palavras Chave: Homossexualidade; Homoafetividade; (In)visibilidade; Preconceito; Artigos Científicos.

\begin{abstract}
This paper presents reflections on the (in)visibility of homosexuality, in especial of homo-affective relationships. It discusses the issue in order to show dimensions of the prejudice surrounding it. Next, it presents a quantitative research regarding scientific publications on the subject. The scientific production in both Brazilian and international journals is still incipient. The paper points out that to give visibility to homo-affectivity may offer society positive references that might contribute to demystify such prejudice.
\end{abstract}

Keywords: Homosexuality; Homo-affectivity (In)visibility; Prejudice; Scientific Articles.

\section{A mídia que tira do armário}

"Desaquenda de Nárnia" - uma expressão a princípio estranha, abrange uma palavra de origem yorubá, língua de matriz africana, e uma história infanto-juvenil. Quem está distante do contato com a comunidade ou cultura LGBTTT (Lésbicas, Gays, Bissexuais, Transexuais, Trangêneros e Travestis) certamente não consegue entender o sentido. O comando é simples: saia do armário!

É usual que grupos minoritários construam seus nichos, guetos, características próprias, seja em termos de locais a frequentar, seja através de vestimentas, hábitos ou linguagens. Alguns elementos da linguagem africana - precipuamente a yorubá - são frequentemente utilizados em ambientes LGBTTT (Sousa, 2009). 
"Aquendar" significa esconder. "Desaquendar", portanto, é revelar, expor. No contexto da expressão título do artigo: sair. Já as crônicas de Nárnia são uma série de sete histórias, de autoria de C.S. Lewis, em que crianças iniciam sua jornada a um mundo paralelo através de um portal existente dentro de um armário. A divertida expressão expõe um palavreado frequente no "mundo gay".

A linguagem, comportamentos, e hábitos homossexuais veem sendo disseminados em nossa cultura nacional há alguns anos. Várias mídias apresentam e divulgam características desse grupo específico. A título de exemplo, o programa de humor CQC - Custe o Que Custar, de 31/03/2014, realizou uma enquete com pessoas na rua para identificação de palavras ou expressões relacionadas à cultura LGBTTT e poucos acertaram os respectivos significados. Apesar do pouco conhecimento com relação às perguntas, o programa em si proporcionou uma divulgação dos termos e gírias utilizados por essa comunidade.

As telenovelas da emissora Globo, que costumam ter a maior audiência de público no Brasil, já há algum tempo têm exposto parte da realidade da cultura homossexual. Utzig e Ferreira (2014) descrevem uma relação de obras televisivas, desde "Torre de Babel" (1998) até “Amor à Vida" (2013), em que homossexuais tiveram papéis de destaque. Esta última telenovela, inclusive, causou grande polêmica e torcida para a demonstração do primeiro beijo gay entre homens da emissora. Agora, a Globo repete a dose apresentando um casal homoafetivo feminino, na telenovela "Em Família".

A demonstração de carinho homoafetivo, como o beijo, contudo, ainda é tabu. A revista Exame.com (Souza, 2014), em matéria do dia 27 de março de 2014, revela que quase $60 \%$ da população se incomoda com o beijo gay público. Os dados foram retirados do estudo "Tolerância social à violência contra as mulheres", divulgados pelo Instituto de Pesquisa Econômica Aplicada- IPEA, que também avaliou a percepção dos brasileiros sobre os homossexuais.

Canais de televisão internacionais, principalmente a cabo, apresentam a cultura homossexual há mais tempo e, na sua maioria, com mais naturalidade. Produzem e lançam seriados específicos que fazem ou fizeram relativo sucesso (Will and Grace, Queer as Folk, The L' Word) ou com personagens gays, lésbicas ou bissexuais (The New Normal, Modern Family, Glee, True Blood), concursos de moda de drag queens (RuPauls Drag's Race), dentre outros. 
A visibilidade costuma se afunilar dependendo da minoria sexual retratada. Uma breve análise empírica já indica que homossexuais masculinos são mais comentados na mídia nacional escrita e televisiva, enquanto homossexuais femininos vem em segundo lugar. Bissexuais permanecem em planos bem secundários no que se refere à exposição, e travestis, transexuais, transgêneros recebem menos atenção ainda.

A maior visibilidade do padrão heteronormativo masculino é confirmada por Rodrigues (2011) em seu artigo "Mídia e Sexualidade: a relação lésbica na revista TPM”. A autora expõe tanto a falta de revistas específicas para o público lésbico, quanto a ausência de nomes reconhecidamente homossexuais femininos nas redações de revistas nacionais. Já referências a tabloides e revistas voltadas para o público homossexual masculino existem desde os anos da ditadura - final dos anos 60 e década de 70, como a Lampião, publicada entre abril de 1978 e junho de 1981 (Simões, 2009).

A revista Veja Brasília (2014), de 19 de fevereiro de 2014, apresentou em sua matéria de capa a situação da comunidade homoafetiva do Distrito Federal, que registra o maior número de casamentos gays do Brasil, em termos proporcionais. A matéria de seis páginas ainda revela que o Distrito Federal possui um dos menores índices nacionais de crimes homofóbicos, ao citar dados do relatório sobre a violência contra os gays da Secretaria dos Direitos Humanos da Presidência da República. Apesar das notícias animadoras com relação à divulgação e proteção jurídica das relações homoafetivas, dos sete casais entrevistados na matéria da revista Veja Brasília, apenas um era feminino.

Os exemplos citados de reportagens da mídia brasileira e internacional apresentam uma realidade - os relacionamentos homoafetivos - cujos direitos tem sido protegidos progressivamente em âmbito mundial e nacional, em termos de legislação e/ou decisões judiciais. Há grandes discussões sociais a respeito da igualdade de condições entre heterossexuais e homossexuais, seja a favor ou contra. A visibilidade é importante. "Sair do armário" gera direitos!

A Organização das Nações Unidas, através do Conselho de Direitos Humanos, em 14 de junho de 2011, em sua $17^{\text {a }}$ sessão, adotou a Resolução 17/19 que trata de direitos humanos, orientação sexual e identidade de gênero. Determinou um estudo documentando leis discriminatórias e a prática de atos de violência contra indivíduos baseadas em sua orientação sexual e identidade de gênero, em todas as regiões do mundo. Preocupou-se, também, em identificar como essas práticas poderiam ser efetivamente combatidas. 
O estudo foi apresentado na $19^{\mathrm{a}}$ sessão do Conselho de Direitos Humanos, em 17 de novembro de 2011 e gerou um relatório, publicado em 2013, que trouxe um amplo histórico de discriminações nas mais diversas áreas em vários países. Houve relatos de morte, sequestro e tortura, leis criminalizando a prática sexual com pessoas do mesmo sexo, impondo pena de morte ou a existência de prisões arbitrárias.

Os países pertencentes à ONU foram conclamados a combater a discriminação também no que se refere à edição de leis, à saúde, educação, restrição de liberdade de reunião e associação. Mais do que isso, foram convidados a enfrentar práticas discriminatórias na família e sociedade, sendo uma dessas práticas a negação de reconhecimento dos relacionamentos homoafetivos. Nesse contexto, os países deveriam promover o acesso a benefícios estatais, além de buscar o reconhecimento da identidade de gênero.

A preocupação com relação à não discriminação dos homossexuais é de extrema relevância e atualidade. A perseguição e intolerância em relação ao público LGBTTT vem de longe, e não é irrelevante que a ONU tenha que se pronunciar e defender a proteção a tais minorias sexuais.

No Brasil, apesar da evidente relutância do Poder Legislativo em aprovar a união civil ou os direitos inerentes à convivência homoafetiva (ou casamento), o Poder Judiciário e o Poder Executivo legitimam e emanam decisões jurisprudenciais ou administrativas sobre o tema. Tais Poderes concordam com um conceito de família e união afetiva mais amplo e vêm concedendo os eventuais benefícios devidos mediante declarações de uniões estáveis, hetero ou homossexuais. ${ }^{1}$

A partir dos anos 90, as discussões a respeito das questões patrimoniais dos casais homoafetivos ganharam espaço no cenário jurídico e social. A judicialização das situações em que a/o companheira/o sequer teve acesso aos bens adquiridos por esforço mútuo, em função de exclusão familiar, tornaram efetiva a questão da consolidação e validação de sua conjugalidade.

Esse processo, no entanto, também é permeado de paradoxos. Enquanto o Poder Judiciário valida e concede direitos a casais homoafetivos, parte do Congresso Nacional brasileiro, fortemente influenciado por bancadas religiosas, procura impedir a concessão de direitos a companheiros e casais homossexuais pela via legislativa.

\footnotetext{
1 STF - Arguição de Descumprimento de Preceito Fundamental n 132/RJ, Tribunal Pleno, Rel. Min. Ayres Brito, DJe 14/10/2011;

Instrução Normativa INSS/PRES n 45, de 6 de Agosto de 2010 - DOU de 11/08/2010.
} 
É importante ressaltar que o reconhecimento formal dos relacionamentos homoafetivos gera consequências sociais, políticas, econômicas, jurídicas. Moralismos e controvérsias à parte, trata-se de uma realidade que não se pode olvidar ou jogar para baixo do tapete.

O resultado do Censo de 2010 do Instituto Brasileiro de Geografia e Estatística IBGE (2012), revelou que 67.445 pessoas se declararam participantes de uma união conjugal homoafetiva. Há uma franca diferenciação entre regiões do território nacional. O sudeste apareceu como a região com o maior número de uniões, e o norte contabilizou o menor número de conjugalidade homoafetiva.

Ora, apesar de vivermos em um país ainda extremamente preconceituoso, principalmente se observadas as desigualdades regionais, quase setenta mil pessoas declararam vivenciar uma união homoafetiva. A princípio, o número pode parecer pequeno, se considerarmos a previsão de $10 \%$ da população ocidental ser constituída predominantemente de praticantes do homoerotismo, segundo o relatório Kinsey (Mott, 2006), mas já se trata de uma revelação muito positiva.

Em primeiro lugar, denota um avanço considerável o fato do Governo Federal ter tirado o público homossexual da obscuridade, e ter incluído expressa e objetivamente a sua presença nas estatísticas populacionais do IBGE. É também significativo o fato das/os participantes assumirem perante as/os pesquisadoras/es do referido órgão não só sua sexualidade, mas a sua situação de conjugalidade.

Tal fato é relevante porque a implementação de políticas públicas leva em consideração os dados obtidos pelo Censo do IBGE. Ademais, as leis e as outras formas de regulamentações administrativas voltadas à comunidade LGBTTT podem trazer à tona maior publicidade para o comportamento homossexual e, consequentemente, provocar a discussão de sua legitimidade perante a sociedade.

A visibilidade é importante! Andrade (2002), em seu trabalho de dissertação de mestrado, procurou apresentar os verdadeiros nomes dos participantes da pesquisa, com a permissão de cada um deles. A auto-exposição e visibilidade permitem a identificação e associação do homossexual a contextos positivos, a geração de empatia, e a desmitificação do seu modo de vida. Em contrapartida, esse esforço coexiste ao mesmo tempo com atitudes individuais e sociais que sujeitamos grupos homoafetivos masculinos e femininos ao desrespeito e preconceito. Nesse contexto, torna-se pertinente retomar a discussão sobre o "armário". 


\section{Homossexualidade e o "armário"}

A homossexualidade constitui, para muitos, em uma doença, perversão ou inversão sexual. Foucault (1988) levanta que foi a partir do século XIX que o homossexual torna-se uma personagem, pois antes seria o sujeito jurídico do ato de sodomia, enquadrado nos artigos de direito civil ou canônico. Fica evidente que se antes o foco era a prática do ato em si, com o tempo, passou a ser a pessoa que o praticava.

Mello prossegue com a ideia (2005, p. 199):

"o campo semântico da homossexualidade - e mais ainda do homossexualismo - e da "identidade homossexual" está constitutivamente marcado pelo contexto médicopatologizante que lhe deu origem na Europa da segunda metade do século XIX"

Passou-se, com o tempo, da criminalização do ato para a patologização de seu agente. Crime, safadeza ou doença? O discurso de médicos, juristas, psiquiatras e peritos criminais versava sobre a etiologia e a capacitação para a cura da condição. E havia uma lógica, principalmente religiosa, para tal postura. Relações homossexuais não geram filhos, o grande dom concedido às famílias e o propósito final das relações sexuais.

A esterilidade implicaria no "comprometimento da viabilidade demográfica e do poderio étnico e religioso da tribo, sendo representada em termos religiosos como castigo" (Rodrigues, 2012, p. 367). A autora mostra que, com a crise demográfica havida na Idade Média, em virtude do elevado número de óbitos ocasionado pelas pestes, as práticas sexuais não procriativas e contraceptivas passaram a ter uma ampla proibição.

Salta aos olhos, neste contexto, a ausência de visibilidade das práticas homossexuais femininas, inclusive com pouca previsão de tipo penal específico para as mulheres. Tal invisibilidade pode ter se dado por desconhecimento e desprezo pela mulher (Rodrigues, 2012). Outros motivos que podem ser pensados além do patriacarlismo é o vínculo da sexualidade da mulher para fins eminentemente procriativos (Falquet, 2009), o que reflete a marca das questões de gênero.

Apesar da maior invisibilidade da homossexualidade feminina, podemos encontrar algumas referências históricas a ela, inclusive no Brasil. Sua prática não só era percebida, como documentada desde o século XVI. Mott (2008) cita a carta enviada 
pelo padre Jesuíta Pero Correia ao Superior da Companhia de Lisboa, em 1551, de São Vicente, no litoral paulista:

"O pecado contra a natureza, que dizem ser lá (em África) muito comum, o mesmo é nesta terra, de maneira que há cá muitas mulheres que assim nas armas como em todas as outras coisas, seguem ofício de homens e tem outras mulheres com quem são casadas. A maior injúria que lhes podem fazer é chamá-las de mulheres. Em tal parte lho poderá dizer algum a pessoa que correrá risco de lhe tirarem a vida às frechadas".

Os relatos apresentados por Mott (2008) demonstram o grau de detalhes em termos de práticas sexuais, suas nomeações e a classificação de seus agentes: fanchonos, tibiras explícitos, sodomitas encobertos etc. As práticas, portanto, não se restringiam à homossexualidade masculina, mas abrangiam os relatos da homossexualidade feminina.

A sodomia no Brasil foi considerada crime, em virtude das Ordenações Manuelinas provenientes de Portugal. O Santo Ofício, em sua primeira visitação ao nordeste, entre 1591 e 1595, investigou casos de mulheres que teriam cometido sodomia, além de outras atuações relacionadas ao homoerotismo masculino (Vainfas, 2006). Todos os casos que eram escondidos e abafados, somente tornaram-se efetivamente visíveis com o acesso aos documentos do Santo Ofício.

Sedgwick (2007) fala da metáfora do armário, ao apontar o Judiciário como expositor do "segredo aberto", a "estrutura definidora da opressão gay no século XX" (p.26). A autora exemplifica com o caso "Bowers contra Hardwick”, da Suprema Corte norte americana, que decidiu pela constitucionalidade do crime de sodomia no estado da Geórgia, quando policiais entraram na casa de Hardwick e o encontraram fazendo sexo com outro homem.

A porta do "armário" não garantiria proteção ou privacidade. A porta fechada apenas esconderia a imagem, a visibilidade da cena, que se exposta, acaba por induzir a um posicionamento expresso, seja do Estado ou de quem busca não se envolver. $A(O)$ homossexual, então, é forçada(o) a sair de seu gueto - auto imposto ou determinado de forma heterônoma pela sociedade (Queiroz, 2008).

A epidemia de AIDS, por outro lado, foi um dos fatores que mais contribuiu para que a sexualidade homoafetiva fosse debatida. Em um primeiro momento esse debate ocorreu de forma negativa, pela caracterização da AIDS como "peste gay” e em função de todo o preconceito nela envolvido. Posteriormente, de uma maneira menos preconceituosa, o debate avançou com a mobilização da sociedade civil pelos direitos 
dos homossexuais (Arán, 2004; Uziel, 2006). Vale ressaltar que os feminismos também ofereceram discussões extremamente relevantes a respeito da sexualidade, ao apresentarem a heterossexualidade como um sistema social baseado na opressão e apropriação das mulheres pelos homens (Falquet, 2009).

A moral vigente sugeria que a/o homossexual poderia ser aceita/o, contanto que celibatária/o. Na pior das hipóteses, era tolerada/o de forma marginal. Aliás, esse é um dos discursos vigentes até hoje na Igreja Católica - ame o pecador, mas odeie o pecado.

A demora em relação ao conceito de homossexualismo deixar de figurar como doença no Cadastro Internacional de Doenças - CID ou como transtorno no DSM Manual Diagnóstico e Estatístico de Transtornos Mentais não é à toa. Somente a partir de 1970 a American Psychological Association deixou de considerar a homossexualidade doença, distúrbio ou perversão. A partir de 1993, a Organização Mundial de Saúde excluiu a homossexualidade como desvio e transtorno sexual.

No tocante ao Brasil, foi em 1985 que o Conselho Federal de Medicina assumiu postura semelhante. Por fim, foi em 1999 que o Conselho Federal de Psicologia publicou portaria que ratificava a homossexualidade como algo normal e condenava as teorias e terapias homofóbicas (Mott, 2006).

A despatologização e desmedicalização abriram a oportunidade para um progressivo aumento da tolerância por parte da sociedade com as relações homoafetivas. Tais relações deveriam, contudo, permanecer no âmbito privado, sem a proteção e o reconhecimento da legislação vigente.

Um dos focos da questão era o dar visibilidade (Arán \& Corrêa, 2004) e o dar voz para os silenciados (Bento, 2007). No entanto, para obtenção de seus direitos civis e penais, os homossexuais precisariam se tornar visíveis, confrontando o padrão heteronormativo vigente (Uziel, A. P., Ferreira, I. T. O., Medeiros, L. S., Antonio, C. A. de O., Tavares, M., Moraes, M. B., Andrade, R. \& Machado, R. S., 2006), mas a que custo? Essa questão merece atenção e reflexão.

\section{A subversão homoafetiva}

A homoafetividade inverte o sistema hierárquico da heteronormatividade. As sociedades ocidentais modernas incluem no topo da pirâmide, em termos de valorização 
social, os heterossexuais casados. Abaixo, estão os heterossexuais não casados. Casais de lésbicas e gays estariam em um dos níveis mais baixos de classificação, que somente "perderia" para os homossexuais promíscuos, os transexuais, travestis, fetichistas etc (Mello, 2006).

A busca pela mencionada estabilidade social criminaliza e marginaliza a homoafetividade. A heterossexualidade se impõe como padrão, sujeita a todos os benefícios do topo da pirâmide. Os demais tipos de relações eróticas ficam, portanto, relegados a um segundo plano. Não é a toa que a prática de sexo homossexual é ou já foi considerada crime em diversos países, conforme exposto pelos estudos realizados pela Organização das Nações Unidas, descritos anteriormente.

Aceitar uniões homoafetivas, quebra, portanto, com toda a lógica intrínseca aos pilares das instituições tradicionais. Rompe com o dualismo de poderes em que o homem é superior à mulher - dominante/dominada, provedor/administradora do lar, ou seja, questiona a segurança de um trilhar conhecido, de uma pretensa estabilidade social, para levar supostamente a sociedade ao indefinido, a rumos desconhecidos.

Mott (2000) nos leva a refletir que o único público/minoria sujeito a preconceito que recebeu tipificação criminal foi o dos homossexuais. Ser negro, índio ou mulher, por si só, jamais foi crime, mas ser sodomita, sim.

A sodomia é condenada pelo Judaísmo e, consequentemente, pelo Catolicismo e Islamismo, pelo fato dessas religiões possuírem a mesma origem. Além de existirem leis civis e penais específicas expressamente contrárias à referida prática ao redor do mundo, o temor à sodomia chega a ponto de muitos círculos sociais evitarem a pronúncia da palavra - pois esta seria "nefanda", impronunciável.

Há que se ressaltar que sodomia não se refere necessariamente à prática do sexo anal, como o senso comum costuma relacionar. Há uma certa indefinição doutrinária a respeito de seu conceito, mas podemos entender a sodomia como a práticas sexuais sem a pretensão de procriação, o que não seria considerado sagrado pelos livros que fornecem a base para as religiões citadas.

Recentemente, é que passa a haver uma progressiva, mas lenta aceitação religiosa para o sexo não procriativo, que busque eminentemente o prazer, contanto que abranja exclusivamente casais heteroafetivos. Somada à condenação religiosa e social, há uma evidente opressão familiar no caso da homoafetividade.

Ao contrário do que ocorre com outras minorias, cuja família se apresenta como grupo de apoio ao enfrentamento da discriminação social, em virtude das similitudes 
entre seus membros, a homoafetividade é, em geral, considerada estranha e também combatida dentro do próprio seio familiar na cultura ocidental cristã. Essa postura gera, muitas vezes, uma dificuldade de aceitação da pessoa dentro de seu próprio núcleo familiar.

Ora, justamente durante o período formativo da pessoa, os ambientes sociais costumam ser extremamente estigmatizantes e refratários à formação da identidade homossexual. Geralmente não é oferecido um bom suporte emocional a esta pessoa, seja na família, escola ou vizinhança, o que favorece o surgimento de uma autopercepção já estigmatizada muitas vezes desde a infância (Rodrigues, 2012).

A família agirá conforme os vínculos existentes entre os pais, os irmãos e demais membros do grupo social. Essa ação sofrerá também a influência da presença ou não de fundamentalismos religiosos ou moralismos sociais, da tradição, da ética, do nível de respeito aos direitos humanos e à autonomia vigente na sociedade à qual ela pertence (Toledo \& Teixeira Filho, 2013).

Ao nível das decisões individuais, o discurso heteronormativo pode forçar um total silenciamento ou constituir um incentivo à exposição da pessoa. Se de um lado o calar gera sofrimento, do outro a exposição indevida pode gerar segregação, produção de estigmas ou até violências físicas e psicológicas no âmbito familiar (Toledo \& Teixeira Filho, 2013).

Jovens entrevistados na cidade de Brasília, que forneceram dados para a tese de doutorado intitulada "Os homossexuais em busca de visibilidade social", de Ribeiro (2005), ao falarem de sua homossexualidade, frequentemente se remeteram às experiências da adolescência. Eles relataram sobre o medo e a angústia que sentiam por estarem fazendo algo "errado".

A pesquisa envolveu a participação de dezesseis jovens, sendo sete (7) do sexo masculino e nove (9) do sexo feminino. As idades variaram entre dezenove (19) e vinte e quatro (24) anos. O nível de escolaridade variou entre o ensino médio e superior. Todos os participantes eram moradores do Distrito Federal, com renda familiar que variava entre $\mathrm{R} \$ 3.500,00$ e $\mathrm{R} \$$ 8.500,00. Tratava-se, portanto, de jovens de classe média, dentro de uma realidade econômica e social específica, mas que apresenta elementos de reflexão interessantes relativos à realidade da comunidade LGBTTT como um todo.

Ocupar esse lugar de exclusão social e familiar revela uma violência implícita e explícita sempre presente na vida das/os homossexuais. Representa uma franca 
demonstração de preconceito nos mais diversos nichos sociais, como família, escola, trabalho, comunidade. Mesmo as/os homossexuais assumidas(os) não costumam explicitar sua homossexualidade em todas as áreas de sua vida. Em certas situações são abertas(os) e em outras não - se fecham em busca de proteção (Castañeda, 2007).

A pessoa homossexual costuma se submeter, em geral, a um processo de invisibilização, o que auxilia a difusão de imagens precipuamente negativas sobre esse segmento. É usual que o medo do preconceito e das manifestações de violência induza os/as homossexuais a frequentarem locais próprios, que, apesar de também oferecerem uma sensação de pertencimento, mantém a invisibilidade do grupo.

Parte da realidade de jovens homossexuais de Brasília é apontada na tese de doutorado de Ribeiro (2005). O autor constatou uma busca de lugares públicos destinados aos homossexuais para que eles pudessem se sentir protegidos da discriminação e do preconceito, ou seja, de locais onde pudessem conhecer outros homossexuais, flertar, namorar. Essa é uma forma de poder forçar laços, partilhar saberes, crenças e valores, conforme indicado pelo pesquisador.

Vivemos hoje em um mundo cada vez mais plural e universal, em virtude da globalização, o que atende à diversidade e permite maior contato com as diferenças. Contraditoriamente, essa mesma sociedade globalizada induz a radicalismos e violências cometidas por quem não consegue lidar com tantas renegociações identitárias e relativismos sociais (Giddens, 2011). Se por um lado a aceitação da homoafetividade é mais divulgada e defendida, por outro lado, as críticas e violências também surgem de forma mais enfática.

A violência passa ao ato, torna-se explícita, e de forma cada vez maior no Brasil. A Empresa Brasil de Comunicação revelou que são registrados oito (8) casos de violência contra homossexuais por dia, através do Disque 100, serviço telefônico da Secretaria de Direitos Humanos da Presidência da República (2013). Voltamos à valsa em que há passos para frente e para trás no que se refere à visibilidade e aos vários tipos de preconceito que envolvem as/os homossexuais.

"Quem não é visto, não é lembrado", já indica o velho jargão das organizações. E quem não é visto nem lembrado, não se torna sujeito de direito, não ganha voz, representatividade social e política ou respeito. Nesse contexto, o estudo de questões acerca da homoafetividade em meios acadêmicos também pode estimular a discussão sobre o tema e garantir visibilidade à pessoa/experiência da/o homossexual como uma referência positiva (Mott, 2000). 


\section{Visibilidade (ou invisibilidade?) acadêmica - levantamento de artigos}

A intenção desse artigo foi identificar em que medida a questão da "homossexualidade" tem sido efetivamente pesquisada, debatida, problematizada e exposta em artigos científicos. Há uma visibilidade a respeito do assunto ou será que também no mundo acadêmico as minorias sexuais permanecem à margem das publicações existentes? Essas perguntas fomentaram a realização de um levantamento de publicações com recorte quantitativo. O objetivo foi identificar o número de artigos sobre a homossexualidade/homoafetividade constantes em bases de dados de periódicos nacionais e internacionais. A importância da questão é patente, por se tratar de pesquisa sobre uma minoria social, cada vez mais exposta nos meios de comunicação, no entanto, ainda vista com resistência e preconceito.

A escolha por periódicos foi feita em virtude de sua relevância em termos de utilização e citações no âmbito da área da psicologia. A busca em periódicos internacionais envolveu uma amostra proveniente de revistas classificadas como "A1" perante a Coordenação de Aperfeiçoamento de Pessoal de Nível Superior - Capes.

O levantamento dos dados foi realizado nos meses de fevereiro e março de 2014 em periódicos que permitiam o filtro por data. Os descritores foram criados de modo a abranger as intercessões entre homossexualidade, homoafetividade e diversas formas de interação mediadas por mídias sociais. Os termos foram pesquisados em publicações dos últimos 10 (dez) anos. A separação dos descritores e de seu número de aparecimento por periódico foi feita com a intenção de permitir uma melhor visualização e de apresentar um parâmetro efetivo de comparação entre os referidos descritores e entre os periódicos. Os descritores, assim como o número absoluto de artigos encontrados para cada descritor nas bases de dados estão expostos na Tabela a seguir: 
Tabela 1: Descritores em português e/ou em periódicos nacionais

\begin{tabular}{|c|c|c|c|}
\hline \multirow[b]{2}{*}{ Descritores em português } & \multicolumn{3}{|c|}{ Número de artigos por base de periódicos } \\
\hline & $\begin{array}{c}\text { Scielo } \\
\text { 475.170 artigos } \\
\end{array}$ & Pepsic $^{8}$ & Capes \\
\hline Homossexualidade & 123 & 38 & 299 \\
\hline Homossexual & 77 & 32 & 246 \\
\hline Gay & 107 & 17 & 169.040 \\
\hline Lésbica & 9 & 1 & 145 \\
\hline Internet & 893 & 76 & 718.630 \\
\hline On line & 2.053 & 84 & 1.235 .526 \\
\hline Virtual & 778 & 94 & 288.719 \\
\hline Mídias sociais & 7 & 0 & 345 \\
\hline Descritores correlacionados & Scielo & Pepsic & Capes \\
\hline Homossexualidade e internet & 0 & 0 & 34 \\
\hline Homossexualidade e on line & 0 & 0 & 6 \\
\hline Homossexualidade e virtual & 0 & 0 & 22 \\
\hline Homossexualidade e mídias sociais & 0 & 0 & 6 \\
\hline Homossexual e internet & 1 & 0 & 42 \\
\hline Homossexual e on line & 0 & 0 & 5 \\
\hline Homossexual e virtual & 0 & 0 & 17 \\
\hline Homossexual e mídias sociais & 0 & 0 & 7 \\
\hline Gay e internet & 2 & 0 & 42 \\
\hline Gay e on line & 0 & 0 & 7 \\
\hline Gay e virtual & 0 & 0 & 5.155 \\
\hline Gay e mídias sociais & 0 & 0 & 12 \\
\hline Lésbica e internet & 0 & 0 & 12 \\
\hline Lésbica e on line & 0 & 0 & 8 \\
\hline Lésbica e virtual & 0 & 0 & 16 \\
\hline Lésbica e mídias sociais & 0 & 0 & 1 \\
\hline Internet e relação & 0 & 0 & 2.387 \\
\hline Internet e relacionamento & 2 & 3 & 569 \\
\hline On line e relação & 1 & 0 & 1.372 \\
\hline On line e relacionamento & 0 & 0 & 220 \\
\hline Virtual e relação & 0 & 0 & 875 \\
\hline Virtual e relacionamento & 1 & 1 & 207 \\
\hline Mídias sociais e relação & 0 & 0 & 270 \\
\hline Mídias sociais e relacionamento & 0 & 0 & 64 \\
\hline Relacionamento e homoafetivo & 0 & 0 & 4 \\
\hline Conjugalidade e homoafetiva & 0 & 1 & 1 \\
\hline
\end{tabular}

Uma primeira verificação quantitativa do número de artigos sobre homossexualidade publicados em periódicos nacionais, com descritores em português revelou a presença de trezentos e dezesseis (316) artigos no Scielo e oitenta e oito (88) artigos no Pepsic, totalizando quatrocentos e quatro (404) publicações. Artigos com os descritores relacionados à virtualidade no Scielo - internet, on line, virtual, mídias

\footnotetext{
${ }^{8} \mathrm{O}$ periódico não informa a quantidade total de artigos publicados
} 
sociais - chegam a três mil setecentos e trinta e um (3.731), enquanto que no Pepsic totalizam apenas duzentos e cinquenta e quatro (254).

Cabe agora problematizar o número de artigos sobre a interação de mídias sociais, internet e relacionamentos encontrados na busca. De acordo com os dados apresentados na Tabela 1 existe um total de seiscentos e cinquenta (650) artigos sobre essa temática no Scielo. No entanto, quando desdobramos a busca para abarcar artigos que retratem as relações entre dimensões da homossexualidade/homoafetividade e internet/mídias sociais, encontramos apenas vinte e um (21) artigos. No caso da base de dados Pepsic o número de artigos cai para um total de quarenta e um (41), sendo que não foi encontrada nenhuma publicação de artigos relativos à temática homossexualidade/homoafetividade e mídias sociais.

Essa primeira análise quantitativa limitou-se à verificação da presença dos termos nos títulos dos artigos, o que trouxe fragilidades na confiabilidade dos resultados, pois somente indicavam um número absoluto de publicações. Nesse sentido:

a) Termos como "gay", "internet", "virtual", "on line" são utilizados tanto em textos em português como em inglês. Portanto, há uma intercessão dos dados em ambas as línguas que não é quantificada na pesquisa ora realizada;

b) O termo "gay" é utilizado como referência não só de assunto, como também de nome de autores. Tal fato precisa ser levando em conta na análise dos dados apresentados que utilizam o descritor mencionado;

c) Os descritores "relação", "relacionamento", "relation" e "relationship" não se restringem a relações afetivas, mas a vários outros tipos de contextos relacionais. São usados, também, como sinônimos de outras palavras, tais como "referência", "lista", "semelhança", "ligação", "correspondência", "nexo", "trato" etc;

d) Os descritores usados em periódicos diferentes, por vezes, apresentaram os mesmos artigos, gerando duplicidade na contagem numérica.

Uma segunda análise foi então realizada, com base na leitura flutuante dos resumos de cada um dos artigos pesquisados. Foram desconsiderados os artigos repetidos em mais de uma base. Os critérios de inclusão foram artigos que tratavam exclusivamente de relações afetivo-sexuais entre homossexuais ou relações afetivosexuais mediadas pela internet/mídias sociais. 
O resultado da segunda fase da pesquisa mostrou a existência de somente três (3) artigos na base de dados Scielo. Na base de dados Pepsic não encontramos nenhum artigo com essa temática. Os números são claros ao demonstrar que a publicação de artigos que abrangem os temas da homossexualidade e de relações homoafetivas, principalmente quando as formas de contato inicial foram virtuais ainda é incipiente.

A Tabela 2 apresentada a seguir mostra os dados referentes a publicações internacionais ou nacionais com descritores em inglês. Não foi colocado nenhum marcador de data inicial. Fica evidente que a escassez de publicações não é algo restrito ao Brasil, pois transparece também nos periódicos internacionais a pouca publicação em termos numéricos sobre a relação mídias sociais e homoafetividade.

Tabela 2: Descritores em inglês em periódicos nacionais e internacionais

\begin{tabular}{|c|c|c|c|c|c|c|c|c|}
\hline $\begin{array}{l}\text { Descritores em } \\
\text { inglês }\end{array}$ & $\begin{array}{c}\text { Scielo } \\
475.170\end{array}$ & Pepsic & Capes & ${\mathrm{JC} \& \mathrm{P}^{9}}^{9}$ & $\begin{array}{l}\text { JC- } \\
\text { CP }\end{array}$ & Sage $^{11}$ & $\begin{array}{c}\text { J. of } \\
\text { Psych. } \\
12\end{array}$ & J.P.S.P \\
\hline Homosexuality & 150 & 45 & 34.153 & 7 & 22 & 4.395 & 55 & 41 \\
\hline Homosexual & 289 & 46 & 32.215 & 12 & 20 & 5.371 & 111 & 30 \\
\hline Gay & 107 & 17 & 169.040 & 31 & 48 & 13.634 & 66 & 39 \\
\hline Lesbian & 73 & 7 & 59.251 & 8 & 8 & 7.243 & 18 & 14 \\
\hline internet & 893 & 76 & 718.630 & 47 & 85 & 39.841 & 54 & 81 \\
\hline on line & 2.053 & 84 & $\begin{array}{c}1.235 .5 \\
26\end{array}$ & 21 & 10 & 8.029 & 382 & 117 \\
\hline virtual & 778 & 94 & 288.719 & 93 & 22 & 22.614 & 382 & 9 \\
\hline Social medias & 439 & 26 & 12.453 & 1 & 2 & 61.459 & 389 & 0 \\
\hline $\begin{array}{l}\text { Descritores } \\
\text { correlacionados }\end{array}$ & Scielo & Pepsic & Capes & JC\&P & JC-CP & Sage & $\begin{array}{c}\text { J. of } \\
\text { Psych. }\end{array}$ & J.P.S.P \\
\hline $\begin{array}{l}\text { Homosexuality e } \\
\text { internet }\end{array}$ & 1 & 0 & 3.775 & 0 & 1 & 963 & 0 & 0 \\
\hline $\begin{array}{l}\text { Homosexual e } \\
\text { internet }\end{array}$ & 0 & 0 & 3.945 & 0 & 0 & 1.092 & 0 & 0 \\
\hline Gay e internet & 3 & 0 & 12.383 & 0 & 0 & 2.886 & 0 & 0 \\
\hline Gay e on line & 1 & 0 & 30.092 & 0 & 0 & 376 & 3 & 0 \\
\hline Gay e virtual & 0 & 0 & 5.155 & 1 & 0 & 1.328 & 0 & 0 \\
\hline $\begin{array}{l}\text { Gay e social } \\
\text { medias }\end{array}$ & 0 & 0 & 742 & 0 & 1 & 5.655 & 0 & 0 \\
\hline Lesbian e internet & 0 & 0 & 6.382 & 0 & 0 & 1.598 & 0 & 0 \\
\hline Lesbian e on line & 0 & 0 & 3.171 & 0 & 0 & 202 & 0 & 0 \\
\hline Lesbian e virtual & 0 & 0 & 2.049 & 0 & 1 & 632 & 0 & 0 \\
\hline Lesbian e social & 0 & 0 & 326 & 0 & 1 & 3.216 & 0 & 0 \\
\hline
\end{tabular}

\footnotetext{
${ }^{9}$ Journal Culture \& Psychology (buscas desde março de 1995);

${ }^{10}$ Journal of Cross-Cultural Psychology (buscas desde março de 1970);

${ }^{11}$ Sage Journals (buscas desde 1847);

12 Journal of Psychology website (148 edições no total);

${ }^{13}$ Journal of Personality and Social Psychology (buscas desde 1965).
} 


\begin{tabular}{l|c|c|c|c|c|c|c|c}
\hline medias & & & & & & & & \\
\hline Internet e relation & 5 & 1 & 79.785 & 2 & 11 & 23.250 & 4 & 0 \\
\hline $\begin{array}{l}\text { Internet e } \\
\text { relationship }\end{array}$ & 4 & 1 & 171.885 & 2 & 10 & 26.842 & 1 & 0 \\
\hline On line e relation & 1 & 0 & 342.782 & 0 & 1 & 95.046 & 1.564 & 0 \\
\hline $\begin{array}{l}\text { On line e } \\
\text { relationship }\end{array}$ & 0 & 0 & 424.936 & 3 & 0 & 108.201 & 1.409 & 1 \\
\hline Virtual e relation & 1 & 0 & 65.319 & 1 & 0 & 13.763 & 1 & 0 \\
\hline $\begin{array}{l}\text { Virtual e } \\
\text { relationship }\end{array}$ & 1 & 0 & 88.377 & 0 & 1 & 14.985 & 0 & 1 \\
\hline $\begin{array}{l}\text { Social medias e } \\
\text { relation }\end{array}$ & 0 & 0 & 3.659 & 0 & 0 & 43.050 & 0 & 0 \\
\hline $\begin{array}{l}\text { Social medias e } \\
\text { relationship }\end{array}$ & 0 & 0 & 5.648 & 0 & 0 & 45.577 & 0 & 0 \\
\hline $\begin{array}{l}\text { Relationship e } \\
\text { homosexual }\end{array}$ & 2 & 2 & 12.188 & 1 & 5 & 3.485 & 6 & 4 \\
\hline $\begin{array}{l}\text { Conjugality e } \\
\text { homosexual }\end{array}$ & 0 & 1 & 54 & 0 & 0 & 16 & 0 & 0 \\
\hline
\end{tabular}

Um primeiro desdobramento da busca para abarcar artigos que retratem as relações específicas entre dimensões da homossexualidade/homoafetividade e mídias sociais, já revela o grau de invisibilidade desse fenômeno. No caso da base de dados Scielo, o número de artigos é de vinte e um (21), no Pepsic não encontramos nenhuma publicação, no Journal Culture \& Psychology são vinte (20), no Journal of CrossCultural Psychology são apenas onze (11), no Journal of Psychology website encontramos cinquenta e quatro (54) e, por último, no Journal of Personality and Social Psychology contabilizamos apenas três (3). O somatório de artigos nas várias bases de dados totaliza cento e nove (109) publicações entre sete mil duzentos e trinta e quatro (7.234) publicações.

Não foram contabilizados os dados da Capes listados nas Tabelas 1 e 2 por englobar periódicos, teses, dissertações. Tampouco agregamos os dados da base Sage Journals porque ela concentra uma multiplicidade de periódicos, muitos deles presentes nas demais bases, o que levaria a uma duplicação de dados. Essas informações foram mantidas nas tabelas no intuito de manter o registro do panorama geral dos dados encontrados.

Dadas as inconsistências levantadas na primeira análise dos títulos dos artigos em inglês, sob os mesmos argumentos já apresentados para a busca de artigos em português nos periódicos Scielo e Pepsic, realizamos nova pesquisa, dessa vez com base na leitura flutuante dos resumos desses artigos. O resultado dessa segunda análise revelou números ainda menores de publicações sobre a temática. No caso da base de 
dados Scielo, o número de artigos é de cinco (5), no Pepsic não encontramos nenhuma publicação.

No Journal Culture \& Psychology foi localizado apenas um (1) artigo, contado duas vezes na tabela por abranger dois descritores: gay e social medias e lesbian e social medias. No Journal of Cross-Cultural Psychology são apenas dois (2) artigos, no Journal of Psychology website encontramos três (3) e, por último, no Journal of Personality and Social Psychology não contabilizamos nenhum artigo. Os resumos dos artigos que continham os descritores relacionados "on line" e "relation" e "on line" $\mathrm{e}$ "relationship" constantes no Journal of Psychology, não foram lidos devido ao volume e abrangência dos dados.

O somatório de artigos nas várias bases de dados totaliza onze (11) publicações entre sete mil duzentos e trinta e quatro (7.234) publicações. Esse resultado mostra que a temática ainda é objeto de poucas publicações. Fica, portanto, a indagação se eventuais pesquisas e reflexões acadêmicas (dissertações e teses) sobre este tema não estariam chegando ao público em geral, por não serem transformadas em artigos publicados.

Diante da exiguidade de artigos referentes à temática nas bases de dados, decidimos realizar uma pesquisa específica em periódicos no campo dos estudos de gênero. A intenção era identificar como se dava a presença de artigos sobre relacionamentos homoafetivos nesse contexto.

Verificou-se que o tema é objeto de uma discussão efetiva apenas quando há edições especiais de revistas dedicadas focalmente ao assunto, ou quando há revistas já direcionadas ao estudo da diversidade, como é o caso da revista BAGOAS - Estudos Gays: Gêneros e Sexualidades, da Universidade Federal do Rio Grande do Norte.

A Revista de Estudos Feministas, da Universidade Federal de Santa Catarina, para nossa surpresa, publicou poucos artigos no que se refere à temática homoafetiva. Nos últimos dez anos, dos 192 artigos publicados, houve apenas treze (13) artigos que abrangiam o referido assunto. O Volume 14, n. 02 (2006), contudo, era temático e trouxe 6 artigos sobre a homossexualidade. Excetuando-se o citado volume, houve apenas 1 artigo com temática exclusivamente lésbica, 1 artigo com temática exclusivamente gay e 1 artigo com temática exclusivamente travesti. Nenhum artigo abordou a temática do impacto das mídias sociais na construção das relações homoafetivas, tema objeto dessa pesquisa. 
Pesquisa realizada na revista Cadernos Pagu do Núcleo de Estudos de Gênero da Universidade Federal de Campinas também revelou escassez semelhante de publicações sobre o tema da homossexualidade/homoafetividade. Nos últimos 10 anos, dos 169 artigos publicados, 10 artigos tinham temática homossexual. Todavia, o Volume 28 (2007) era temático, com 9 artigos sobre o tema. Significa dizer que, ao se desconsiderar a edição temática, houve somente 1 artigo com temática homossexual, 1 artigo com temática travesti e 1 artigo com temática drag queen.

Não podemos deixar de mencionar que existem vários periódicos estrangeiros que tratam especificamente da temática homossexual. Dentre eles destacamos: Journal of Gay and Lesbian Psychotherapy, Journal of Bisexuality, Journal of Homosexuality, Journal of LGBT Youth, Journal of LGBT Health Research, Journal of Gay and Lesbian Psychotherapy, Journal of Gay and Lesbian Social Services, Journal of Homosexuality, Journal of Gay \& Lesbian Issues in Education, Journal of GLBT Family Studies, Journal of LGBT Issues in Counseling. Não foi realizada uma busca bibliográfica nesses periódicos uma vez que a intenção da pesquisa foi mostrar a pouca publicação do assunto em periódicos não temáticos.

O panorama traçado indica a incipiência de publicações que abrangem a relação entre o uso de mídias sociais/internet na construção de relacionamentos homoafetivos, tendo como referência a quantidade de artigos publicados na área da psicologia sobre a questão. Trata-se de um mapa, de uma representação da realidade numérica atual. Não há elementos para afirmar os motivos dessa falta de representatividade, mas ela transparece na pesquisa realizada.

O surgimento das mídias sociais tem sido apresentado na imprensa leiga como um fator que vem provocando uma verdadeira revolução nas possibilidades de relacionamento. Apontamos ao longo do texto que esta estratégia constitui uma forma relevante de contato tanto nas comunidades homoafetivas quanto heterossexuais. Este fenômeno ainda não está visível na produção artigos.

\section{5. $\underline{\mathrm{O} \text { entreabrir de portas }}$}

Um breve viajar pela história recente de nossa civilização ocidental revela um número ímpar de exemplos de perseguições, desqualificação, preconceito e, no mínimo, invisibilidade da experiência dos grupos homossexuais. Estatísticas e levantamentos 
realizados pelo Governo ou por organizações não-governamentais comprovam a desqualificação que a comunidade LBGTTT enfrenta socialmente.

As práticas de violência ou segregação podem ser percebidas nesse grupo, talvez de forma mais acirrada do que nas demais minorias sociais, que não conseguiriam esconder suas características identitárias, como aponta Mott (2000). A invisibilidade da orientação sexual, como forma de proteção individual, pode ser extremamente cruel, e certamente constitui uma forma de violência.

Ainda há um certo estranhamento ou surpresa da sociedade em geral quanto ao exercício de direitos e à manifestação clara da opção sexual/conjugal da comunidade LGBTTT. Esse comportamento parte inclusive de homossexuais que não estejam habituados com ambientes e contextos sociais que respeitem sua orientação e garantam o exercício de seus direitos, dentre eles, a visibilidade.

Esse tipo de reação ocorre, por exemplo, quando encontram homens andando de mãos dadas nas ruas, em cidades como São Francisco e Montreal (Andrade, 2002; Uziel, 2006). Nesse contexto, a demonstração de carinho entre homens é mais passível de estranhamento do que as mesmas demonstrações entre mulheres. Tal estranhamento é produto da cultura heteronormativa patriarcal em que vivemos na sociedade ocidental, e de modo especial no Brasil.

Há quase quinze anos atrás, uma edição da revista Superinteressante mostrava que o sexo entre animais do mesmo sexo era frequente e documentado, mas não era divulgado pela comunidade científica. A reportagem sugeriu a presença de homofobia nos meios científicos, que deveriam possuir uma "suposta" postura de neutralidade. A continuidade do discurso de "antinaturalidade" das relações sexuais homossexuais prosseguiu integrando ideologias científicas (Burgierman, 1999; Junqueira, 2007).

O conhecimento psicológico está cada vez mais popularizado, passando do privado para o público (Neckel, 2007). O maior aprofundamento de pesquisas sobre as relações homoafetivas tem por função permitir a exposição do assunto para a sociedade e sua discussão, como já ressaltava Foucault em 1988.

Pesquisas trazem o potencial de dar visibilidade à temática e impõem posicionamentos, nos mais diversos meios sociais - científico, familiar, religioso, legislativo, etc. Esse processo carrega o potencial de gerar/promover mudanças no status quo, geralmente positivas. Isso é importante para aqueles grupos sociais que são apresentados como coadjuvantes ou figurantes. Nesse contexto, eles podem passar a ser protagonistas de suas histórias. 
A exposição forçada das preferências sexuais das pessoas em geral, sejam "anônimas" ou famosas, conforme defendido por certos militantes de direitos homossexuais, todavia, não se mostra adequada, por se tratar de opção de cada pessoa a divulgação desse tipo de informação. É patente, contudo, que a visibilidade do público homossexual traz mais benefícios que prejuízos para a categoria como um todo.

O fato é que andamos dois passos, voltamos um, andamos três, voltamos dois, e essa valsa prossegue, indefinidamente. Esse vai e vem, paulatinamente, favorece que novos direitos sejam conferidos aos homossexuais. Aquelas e aqueles que resolvem se expor ou defender expressamente seus direitos tornam o grupo aparente e, muitas vezes, desmistificam as imagens e preconceitos formados pelo fato da sociedade tomar como referência o padrão heteronormativo.

Brasília é uma cidade onde há bares, boates, saunas, cafés, cinemas pornô, voltados ao público LGBTTT. De fato, mais destinado ao "G" do que aos outros. Podemos encontrar namorados e namoradas andando de mãos dadas no shopping, trocando carinhos em bares e restaurantes, ou seja, se mostrando mais expressivamente. Os cartórios civis de Brasília já realizavam o registro de união civil entre pessoas do mesmo sexo, sem maiores empecilhos, mesmo antes da determinação expressa do Conselho Nacional de Justiça.

De Brasília, saiu a cantora Ellen Oléria, ganhadora da primeira edição do programa The Voice Brasil, ocorrida no dia 16 de dezembro de 2012, na Rede Globo. A emissora, reconhecidamente tradicionalista, filmou e nomeou textualmente na legenda a presença da mãe e da namorada da cantora durante as suas apresentações finais. Negra e lésbica, ela foi vista, sua condição afetiva foi comentada e ela foi a vencedora da competição! Isso representa, sem sombra de dúvidas que ocorreram avanços.

Outras cantoras mais conhecidas saíram do armário utilizando redes sociais, como é o caso de Maria Gadu e Daniela Mercury (Giusti, 2013). Aos poucos, o mundo fantasioso e fechado de um armário se apresenta à realidade das mídias sociais virtuais e reflete no chamado "mundo real". Elas e eles que desaquendam de Nárnia mostram a cara à tapa. Oferecem exemplos a seguir e apresentam possibilidades de reflexão à respeito da diversidade emocional e sexual.

Há avanços a comemorar! 


\section{REFERÊNCIAS}

Andrade, A. J. A. (2002). Visibilidade gay, cotidiano e mídia: Grupo Arco-Íris: consolidação de uma estratégia: um estudo de caso. Dissertação (Mestrado em Comunicação)-Faculdade de Comunicação, Universidade de Brasília, Brasília;

Arán, M. \& Correa, M. V.(2004). Sexualidade e política na cultura contemporânea: o reconhecimento social e jurídico do casal homossexual. Physis, Rio de Janeiro, v. 14, n. 2, July 2004. Recuperado em 11 de dezembro de 2012, de http://www.scielo.br/scielo.php?script=sci_arttext\&pid=S0103-

$73312004000200008 \& \operatorname{lng}=\mathrm{en} \& \mathrm{nrm}=\mathrm{iso}$;

Bento, B. (2007). Corporalidades transexuais: entre a abjeção e o desejo. In Leituras em rede: gênero e preconceito. Org. Cristina Scheibe Wolff, Marlene de Fáveri, Tânia Regina Oliveira Ramos. Editora Mulheres.

Brasil, Instituto Brasileiro de Geografia e Estatística - IBGE (2012), Censo 2010. Recuperado em 05 de dezembro de 2013, de http://www.censo2010.ibge.gov.br/resultados;

Burgierman, D.R. (1999). Atração entre iguais. Superinteressante n. 143, Editora Abril;

Cadernos Pagu (2007). Universidade Estadual de Campinas. Recuperado em 02 de março de 2014, de http://www.pagu.unicamp.br/en/cadernos-pagu;

Falquet, J. (2009). Romper o tabu da heterossexualidade, acabar com a "diferença dos sexos": contribuições do lesbianismo como movimento social e teoria política. In Leituras em rede: gênero e preconceito. Org. Cristina Scheibe Wolff, Marlene de Fáveri, Tânia Regina Oliveira Ramos. Editora Mulheres.

Foucault, M. (1988). História da Sexualidade I: A vontade de saber. Trad. Maria Thereza da Costa Albuquerque e J. A. Guilhon Albuquerque. Graal, Rio de Janeiro, 176 $\mathrm{p}$

Foucault, M. (1984). História da Sexualidade II: O uso dos prazeres. Trad. Maria Thereza da Costa Albuquerque e J. A. Guilhon Albuquerque. Graal, Rio de Janeiro, 333 $\mathrm{p}$

Giddens, A (2011). Mundo em descontrole: o que a globalização está fazendo de nós. Trad. Maria Luiza X. de A Borges. 4. Ed. Rio de Janeiro, 107p;

Giusti, I. (2013). Daniela Mercury, Maria Zilda, Gadú: redes sociais como meio para sair do armário. iGay, portal IG. Recuperado em 17 de dezembro de 2013, de $\mathrm{http} / / /$ igay.ig.com.br/2013-11-14/daniela-mercury-maria-zilda-gadu-redes-sociaiscomo-meio-para-sair-do-armario.html;

Junqueira, R. D. (2007). Homofobia: limites e possibilidades de um conceito em meio a disputas. Revistas Bagoas, Rio Grande do Norte, V.1, n.1, Jul/Dez. 2007. Recuperado em 20 de fevereiro de 2014, de www.cchla.ufrn.br/bagoas/edic01.html; 
Mello, L. (2005). Outras famílias: a construção social da conjugalidade homossexual no Brasil. Cad. Pagu, Campinas, n. 24, Junho 2005 . Recuperado em 06 de março de 2014, de http://www.scielo.br/scielo.php?script=sci_arttext\&pid=S0104$83332005000100010 \& \operatorname{lng}=$ en\&nrm=iso;

Mello, L. (2006). Familismo (anti)homossexual e regulação da cidadania no Brasil. Revista Estudos Feministas, Florianópolis, v. 14, n. 2, Setembro 2006. Recuperado em 19 de fevereiro de 2014, de <http://www.scielo.br/scielo.php?script=sci_arttext\&pid=S0104026X2006000200010\&lng=en\&nrm=iso>;

Mott, L. (2000). Por que os homossexuais são os mais odiados dentre todas as minorias? In: Palestra preparada para o Seminário Gênero \& Cidadania: Tolerância e Distribuição da Justiça. Núcleo de Estudos de Gênero - Pagu, Unicamp, 6-12-2000. Recuperado em 19 de dezembro de 2013, de http://www.ifch.unicamp.br/pagu/sites/www.ifch.unicamp.br.pagu/files/colenc.01.a09.p df;

Mott, L. (2006). Homo-afetividade e direitos humanos. Rev. Estud. Fem., Florianópolis, v. 14, n. 2, Sept. 2006. Recuperado em 19 de dezembro de 2013, de http://www.scielo.br/scielo.php?script=sci_arttext\&pid=S0104-

026X2006000200011\&lng=en\&nrm=iso;

Mott, L. (2008). Pré-história da homossexualidade em São Paulo: 1532-1895. DIALOGUS - Revista das Graduações em Licenciatura em História e Geografia. V.4, n.1. 2008. Recuperado em 18 de dezembro de 2013, de http://baraodemaua.br/comunicacao/publicacoes/dialogus/2008/pagina3.html;

Neckel, R. (2007). A "ciência sexual" e os "guias" do "casal moderno". In Leituras em rede: gênero e preconceito. Org. Cristina Scheibe Wolff, Marlene de Fáveri, Tânia Regina Oliveira Ramos. Editora Mulheres.

ONU - Organização das Nações Unidas (2013). Combatting discrimination based on sexual orientation and gender identity. Recuperado em 19 de dezembro de 2013, de http://www.ohchr.org/EN/Issues/Discrimination/Pages/LGBT.aspx;

Queiroz, C. M. (2008). Estigmas, guetos e gentrificação: a segregação homossexual em Brasília. Dissertação de mestrado. Instituto de Ciências Sociais, Departamento de Sociologia, UnB. Recuperado em 04 de abril de 2014, de http://repositorio.unb.br/handle/10482/2065?mode=full;

Revista Bagoas - Estudos gays: gêneros e sexualidades (2012). Universidade Federal do Rio Grande do Norte. Recuperado em 02 de março de 2014, de http://www.cchla.ufrn.br/bagoas/;

Revista de Estudos Feministas (2006). Universidade Federal de Santa Catarina. Recuperado em 02 de março de 2014, de http://refe.paginas.ufsc.br/revistasanteriores/volumes-11-ao-15/volume-14-no-2-2006/; 
Ribeiro, A. S. M. (2005). Os homossexuais em busca de visibilidade social. Tese de doutorado. Instituto de Psicologia, UnB;

Rodrigues, B. M. (2011). Mídia e Sexualidade: a relação lésbica na revista TPM. Sexualidad, Salud y Sociedad (Rio de Janeiro), (9), 91-108. Recuperado em 04 de Abril de 2014, de http://www.scielo.br/scielo.php?script=sci_arttext\&pid=S198464872011000400005\&lng=en\&tlng=pt. 10.1590/S1984-64872011000400005;

Rodrigues, R. C. C. (2012). Homofilia e homossexualidades: recepções culturais e permanências. História (São Paulo), 31(1), 365-391. Recuperado em 05 de abril de 2014, de http://www.scielo.br/scielo.php?script=sci_arttext\&pid=S010190742012000100018\&lng=en\&tlng=pt. 10.1590/S0101-90742012000100018;

Sedgwick, E. K. (2007) A epistemologia do armário. Cadernos pagu (28), janeiro-junho de 2007:19-54;

Simões, J. A. (2009). Antes das letrinhas: homossexualidade, identidades sexuais e política. In Leituras em rede: gênero e preconceito. Org. Cristina Scheibe Wolff, Marlene de Fáveri, Tânia Regina Oliveira Ramos. Editora Mulheres;

Sousa, A. M. (2009). Mona paródica...dá mais pinta, bonita: análise léxico-semântica da gíria dos homossexuais de Fortaleza. Revista Philologus, Ano 15, $\mathrm{N}^{\circ}$ 44. Rio de Janeiro: CiFEFiL, maio/ago.2009. Recuperado em 04 de Abril de 2014, de http://www.filologia.org.br/revista/44/07.pdf;

Souza, B. (2014). Gays se beijando na rua incomodam 6 de cada 10 brasileiros. Exame.com. Recuperado em 06 de Abril de 2014, de http://exame.abril.com.br/brasil/noticias/gays-se-beijando-na-rua-incomodam-x-dosbrasileiros;

Toledo, L. G., \& Teixeira Filho, F. S. (2013). Homofobia familiar: abrindo o armário 'entre quatro paredes'.Arquivos Brasileiros de Psicologia, 65(3), 376-391. Recuperado em 04 de maio de $2014, \quad$ de http://pepsic.bvsalud.org/scielo.php?script=sci_arttext\&pid=S1809-

52672013000300005\&lng=pt\&tlng=pt;

Utzig, I. L. A. \& Ferreira, R. A. (2014). Literatura Gay como visibilidade à comunidade LGBTTT. Artigo de conclusão de curso dos acadêmicos de Licenciatura plena em Letras com habilitação em Língua Inglesa. Universidade Federal do Amapá (UNIFAP). Recuperado em 07 de abril de 2014, de http://pt.slideshare.net/larautzig/literatura-gaycomo-visibilidade-comunidade-lgbttt\#;

Uziel, A. P., Ferreira, I. T. O., Medeiros, L. S., Antonio, C. A. de O., Tavares, M., Moraes, M. B., Andrade, R. \& Machado, R. S. (2006). Parentalidade e conjugalidade: aparições no movimento homossexual. Horiz. antropol., Porto Alegre, v. 12, n. 26, Dec. 2006 . Recuperado em 19 de dezembro de 2013, de http://www.scielo.br/scielo.php?script=sci_arttext\&pid=S0104-

$71832006000200009 \& \operatorname{lng}=\mathrm{en} \& \mathrm{nrm}=\mathrm{iso}$; 
Vainfas, R. (2006). Homoerotismo feminino e o Santo Ofício. História das mulheres no Brasil. Org. Mary Del Priori. $8^{a}$ Ed., São Paulo: Contexto, 678 p. 


\title{
ARTIGO III - MONA, NÃO FAZ A EGÍPCIA! - UMA REVISÃO SISTEMÁTICA DE CONTEÚDO
}

\section{RESUMO}

O presente artigo se propõe a apresentar um panorama do uso da internet e mídias sociais como forma de contato em relações hetero e homoafetivas no Brasil. Para tanto, foi feita uma revisão sistemática de conteúdo de artigos publicados sobre o tema em periódicos brasileiros. Os resultados foram apresentados em categorias que mostram a complexidade do uso da tecnologia como mediadora em relacionamentos afetivos.

Palavras Chave: Relações; Virtualidade; Homoafetividade; Heteronormatividade; Revisão Sistemática.

\begin{abstract}
This article aims to give an overview of the usage of the Internet and other social medias as a form of contact in heterosexual and homosexual relationships in Brazil. A systematic review of literature of the articles published on the subject in Brazilian journals was done. The results are presented under several categories that show the complexity involved in the usage of technologies as a mediator in affective relationships.
\end{abstract}

Keyword: Relationships; Virtuality; Homo-Affectivity; Hetero-normativity; Systematic Review

\section{Guetos virtuais ou possibilidades contemporâneas?}

As formas de contato oportunizadas pela internet e mídias sociais apresentam uma nova alternativa de aproximação que pode inverter a lógica usualmente adotada pelas pessoas para se conhecerem. Grupos se unem em virtude de assuntos e interesses comuns, sem que haja uma efetiva apresentação de seus usuários. Amizades e casais se formam por informações disponibilizadas por si mesmos em perfis criados para ampliar redes sociais ou conhecer parceiros para relacionamentos amorosos e/ou sexuais, dentre várias outras alternativas.

As opções oferecidas pelas mídias sociais são inúmeras. O presente artigo problematizará sua utilização, tanto por homossexuais quanto por heterossexuais, uso 
esse que tem suas singularidades de acordo com cada grupo. Os dados e reflexões têm por base revisão sistemática de artigos que abordam o tema. Uma das hipóteses levantadas é de que o uso da virtualidade pode ser considerado uma espécie de gueto virtual. Outra hipótese é que seria apenas mais uma possibilidade de contato e conhecimento intermediada pela tecnologia.

O gueto é considerado uma área urbana restrita, que agrega grupos específicos, portadores de certos valores e formas de pensar, que propicia o isolamento de uma categoria de pessoas estigmatizadas. Guetos podem ser formados por imposição externa ou de forma natural, por afinidades, valores e necessidades comuns, através de ações dos próprios componentes do grupo (Queiroz, 2008).

Nosso argumento aqui é que tal definição também pode ser aplicada a grupos que se formam através dos diversos tipos de mídias sociais existentes. O conceito se encaixa, contanto que imaginemos não haver um espaço físico efetivo, mas consigamos entender as inúmeras possibilidades geradas pelos meios virtuais. $\mathrm{O}$ mundo virtual permite a agregação de pessoas que compartilham ideias, valores, interesses e/ou que sofrem processos de exclusão comuns. Os contatos são praticamente imediatos, sem a necessidade de um agrupamento geográfico ou pessoal.

Os guetos, sejam entendidos como lugar físico efetivo para junção de um grupo ou um meio de contato virtual, também poderiam ser considerados uma forma de autoproteção, no caso dos homossexuais. Os dados da violência homofóbica no Brasil indicam que ainda estamos longe de uma convivência pacífica e com respeito efetivo aos direitos humanos da comunidade LGBTTT.

O $2^{\circ}$ Relatório sobre Violência Homofóbica, realizado pela Secretaria de Direitos Humanos da Presidência da República (SDH/PR) em 2012 e divulgado em junho de 2013, demonstra um aumento em $166 \%$ de denúncias realizadas por telefone. Foram utilizados como referência e fonte de dados o Disque 100, da SDH/PR; o Ligue 180, da Secretaria de Políticas para as Mulheres (SPM); e a Ouvidoria do Sistema Único de Saúde (SUS), do Ministério da Saúde.

O Relatório aponta que as denúncias mais comuns envolviam violência psicológica, discriminação e violência física. Apesar da conhecida e admitida subnotificação das violências, um dado interessante é que em 2011 a maioria dos registros veio da própria vítima e no ano de 2012 a maior parte das ligações foi apresentada por terceiros que observaram as violações. 
Esse dado novo sobre a fonte das denúncias sugere que há uma maior sensibilidade e preocupação de partes da sociedade no que se refere à violência cometida contra a comunidade LGBTTT. O aumento de notificações não permite afirmar em quanto, numericamente, há um efetivo aumento da violência, pois a ampliação de registros pode ser proveniente de uma maior conscientização de direitos sociais, seja de quem sofre a violência, seja de quem presencia seu cometimento.

O $2^{\circ}$ Relatório sobre Violência Homofóbica apresenta recortes bem delimitados, abrangendo vários tipos de violências. Traz uma divisão relativa à orientação sexual e identidade de gênero, apresenta números por idade, estados, tanto dos autores da violência quanto das vítimas. Disponibiliza, ainda, gráficos que permitem uma boa visualização dos dados apresentados, constituindo-se em uma fonte de informação extremamente relevante.

O referido Relatório da SDH/PR constatou que há uma predominância majoritária de vítimas do sexo masculino $(71,38 \%)$. As travestis foram as que mais sofreram violência $(51,68 \%)$, seguidas de gays $(36,79 \%)$ e Lésbicas $(9,78 \%)$ A faixa etária das vítimas, em sua maioria, foi de 18 a 29 anos (59,93\%), ou seja uma população adulta jovem. Um dado que merece atenção é o fato de que $61,9 \%$ dos suspeitos de praticarem violência eram conhecidos de quem sofreu a violência - vizinhos, seguidos de familiares.

Pode-se constatar um certo equilíbrio nos números relacionados às vítimas de violência homofóbica, quando se foca nos locais em que as violações de direito ocorreram. A maior parte aconteceu em locais privados $(38,63 \%)$, seguida por locais públicos $(30,89 \%)$. Esse dado indica que a comunidade LGBTTT ainda tem que adotar vários cuidados para prevenir agressões das mais diversas ordens.

A realidade do Distrito Federal, contudo, é pontual. Por um lado, apresenta os menores índices nacionais de crimes homofóbicos (Campbell, 2014), por outro é o líder de denúncias no país, conforme o $2^{\circ}$ Relatório sobre Violência Homofóbica $(9,30$ denúncias por 100 habitantes). Os números apresentados indicam uma conscientização mais efetiva da população, o que gera uma mobilização maior para o registro de violências sofridas.

A violência contra grupos homoafetivos, portanto, existe! É registrada, estudada e divulgada. É psicológica e é física. Logo, a preferência de pessoas ligadas à comunidade LGBTTT por frequentar lugares específicos para homossexuais tem 
fundamento, seja por estigma, por segregação voluntária ou por necessidade de autoproteção (Queiroz, 2008).

Cabe então perguntar em que medida os artigos científicos produzidos a respeito de relacionamentos que se iniciam ou se mantêm de forma virtual entre pessoas do mesmo sexo tratam essa forma de contato como uma segregação. Ou será que apontam se tratar de uma nova possibilidade de aproximação - diferente, mas que mantém as características de tantos outros meios de interação?

Esse questionamento nos remete à ideia de "fazer a egípcia" - uma expressão utilizada no ambiente LGBTTT que indica certo desprezo por alguma coisa ou alguém, por meio do ato de virar a cara. É proveniente da posição dos rostos virados para o lado em gravuras do antigo Egito. Mona, expressão também comum no meio LGBTTT, caracteriza mulher ou homossexual masculino afeminado. O artigo, todavia, é direcionado a todas e todos que se disponham a conhecer um pouco de uma realidade exposta - o que os artigos científicos nessa área da psicologia tem abordado.

A proposta ora apresentada, portanto, é que as opções e alternativas de contatos virtuais utilizadas pela comunidade LGBTTT sejam vistas e analisadas de frente. Decorre daí o interesse em identificar artigos que abordem o assunto e que problematizem a motivação para o uso de mídias sociais como forma de contato em relações afetivas, e principalmente nos relacionamentos homoafetivos.

\section{O lugar (papel) da internet e mídias sociais nas relações (homo)afetivas}

De forma geral, a natureza interativa do ciberespaço oferece oportunidade de igualdade (em virtude da possibilidade de não identificação das características físicas dos indivíduos que ali conversam) e sedução, em razão da imaginação e disponibilidade de quem interage no ciberespaço (Araújo, 2009). Tais situações podem perdurar por um determinado tempo, com trocas de intimidade, fidelidade, privacidade, mesmo que virtuais, ou se transformar em relações pessoais e físicas. Contudo, a transformação do virtual em real é considerada, normalmente, uma consequência lógica, segundo alguns estudos na área (Dela Coleta; Dela Coleta \& Guimarães, 2008; Donnamaria \& Terzis, 2009 e 2012; Silva \& Takeuti, 2010).

A concepção de identidade do sujeito pós-moderno "encontra nas salas de batepapo virtuais um ambiente propício, onde o sujeito pode ser aquilo que desejar, 
inclusive ele próprio, desde que o contexto seja conveniente" (Civiletti \& Pereira, 2002). Cada pessoa pode criar personagens conforme seus interesses momentâneos ou objetivos (Nussbaumer, 2005), que podem corresponder ou não ao que efetivamente exista no "mundo real".

A privacidade que a internet proporciona vai ao encontro do exposto por Sanders (2002), ou seja, ela permite o contato entre as pessoas de forma virtual, sem identificação, exposição ou necessidade de submissão a comportamentos preconceituosos. Com um simples apertar de botão, a ligação entre os participantes da conversa se interrompe. Garante-se a privacidade, sem a necessidade de manter ou confrontar um segredo, o que seria mais usual em uma conversa "olho no olho".

Para entender melhor as amplas opções e alternativas hoje existentes, é interessante abordar o desenvolvimento da internet e seus variados programas destinados ao contato ou conversação. Em seguida é importante apontar as muitas mudanças que ocorreram em termos de meios para aproximações virtuais e para a manutenção dessas relações, com a implementação de diversos tipos de mídias sociais.

A título de esclarecimento, mídias sociais são definidas como aplicativos e programas que permitem a criação e compartilhamento de conteúdos gerados por usuários. De forma geral, abrangem a Wikipedia, YouTube, Facebook, Second Life (Kaplan e Haenlein, 2010). Veja que se trata de conceito extremamente amplo. Os exemplos citados pelos autores são de dicionário formado e complementado com a participação de usuários da internet; de programa de disponibilização de vídeos; de programa de redes sociais; e um jogo virtual, em que há criação de avatares (personagens virtuais) e de um mundo que permite contato entre usuários através dos referidos avatares.

O momento atual, que permite tantas possibilidades em termos de contato de usuários de computadores, foi precedido de outras formas de contatos virtuais mais incipientes e limitadas. O período comercial da internet no Brasil iniciou, efetivamente, em 1995, quando seu uso cresceu vertiginosamente. A maior novidade em termos de contato imediato, on line, foram os "chats", tendo grande difusão o "Internet Relay Chat" (IRC). A/o usuária/o poderia escolher um canal, que variava conforme suas áreas de interesse (Dela Coleta, Dela Coleta \& Guimarães, 2008). Concomitantemente, também foram criadas listas de discussão, mas ao contrário dos chats, o contato dependia da utilização de $e$-mails, sem a característica de instantaneidade no contato. 
Os canais do IRC (existentes ainda hoje) e suas/seus usuárias/os costumam ser registrados, de forma a garantir a posse daquele nome ou apelido. Os canais são munidos de operadoras/es, pessoas que comandam e fiscalizam a sua utilização, com poderes para limitar, impedir ou retirar o acesso daquelas/es que se comportarem de maneira que não se coadunam com a proposta do canal. Surgiram, então, canais com as mais variadas temáticas, dos quais podemos citar, a título de amostra, o \#gaybrasil, \#gay-rio, \#gaysp, \#gaybrasilia, \#gayjovem, dentre vários outros que, apesar de majoritariamente masculinos, possuíam frequência feminina, tanto de homo como heterossexuais simpatizantes.

Pesquisa realizada no final da década de 1990, para o Centro de Pesquisa de Mídia de Massa na Escola de Jornalismo e Comunicação de Massa da Universidade do Colorado, demonstrou uma boa interatividade da vida real com a vida virtual entre as/os usuárias/os. Os conhecimentos adquiridos fora da internet indicavam os canais a serem frequentados virtualmente, e os canais permitiam uma interação que poderia gerar encontros reais (Leal, 2013). Tal conexão não se restringiu ao Colorado ou Estados Unidos, mas pôde ser verificada também no Brasil.

Programas como o ICQ (I Seek You), surgido em 1997, ou o Messenger permitiram que os contatos fossem mais restritos, havendo uma listagem remota, cuja inclusão dependeria do interesse e aceitação de ambos. Com o surgimento dos referidos programas, não houve mais necessidade em se conectar a um servidor ou a um canal específico, uma vez que a ligação seria "direta" entre os computadores, gerando uma maior privacidade e controle. Uma das grandes inovações foi o contato via webcam, permitindo que as/os interlocutoras/es pudessem ter contato também por voz e imagem.

Já no final dos anos 90, surgiram as salas de bate papo, controladas por determinados sites, que especificam o assunto e limitam o número de acessos para assinantes e não assinantes. O controle é menor do que o realizado no âmbito do IRC e, até os dias de hoje, possui um grande acesso de usuários. Sua inovação foi permitir a postagem de fotos nas salas em tempo real, cujo teor varia conforme sua temática.

Em 2004, houve o surgimento do Orkut, rede social vinculada ao Google, que além de consistir em um site de relacionamentos era uma rede social em que as pessoas tinham a possibilidade de se aproximar pelos mais diversos motivos, seja por gostos, hábitos, afinidades ou comunidades em comum (Lopes, G., Luccas, R., Teixeira, E.dA, 2011). Segundo a revista eletrônica Veja.com, em junho de 2004, a mencionada rede social já contava com mais de 2 milhões de usuários no mundo. A matéria destacava 
como grande inovação a facilidade de cada usuário montar uma página com seu perfil, contendo informações pessoais.

No mesmo ano, foi criado o Facebook, por um aluno da Universidade de Harvard, também com as características semelhantes ao Orkut, mas com maior controle de privacidade. Houve, então, uma intensa popularização do Facebook no Brasil, com forte migração dos usuários do Orkut (Lopes, G.L., Luccas, R., Teixeira, E.dA, 2011), talvez em virtude de sua maior permeabilidade em outros continentes, como os EUA ou os países pertencentes à Comunidade Econômica Europeia.

Concomitantemente, sites com propostas de realizar contatos homoafetivos foram surgindo, como o Disponível (brasileiro), Manhunt, Gaydar, dentre vários outros, em que o usuário também cria um perfil, contendo descrições físicas, gostos, objetivos, afinidades, fotos ou filmes. O perfil pode abranger propostas desde as mais românticas até sugestões de encontros para sexo casual. Os referidos sites, contudo, apresentam cunho visivelmente mais erótico, permitindo a seus usuários que exponham fotos com nudez ou sexo.

$\mathrm{O}$ acesso aos mencionados sites é majoritariamente masculino, talvez pelas características a ele inerentes, como a exposição de fotos sensuais ou com cunho sexual. Conforme ressaltado por Féres-Carneiro (2001, p. 72), nossa cultura masculina costuma valorizar "atributos físicos - beleza, jovialidade - e a atração física em suas escolhas amorosas". Ademais, muitas das fotos apresentam apenas partes do corpo, gerando uma forma de atração imediata e sem a necessidade de identificação do rosto da pessoa (Zago, 2013).

Foram criados também sites destinados ao encontro entre mulheres, como o Brenda, LesbianPersonals, Private Lesbian, Qrushr, Gayvox (Viega, 2014). Somente os três primeiros exclusivamente para o público feminino. O Qrushr também é voltado para usuários heterossexuais e gays e o Gayvox abrange o público homossexual masculino e feminino.

Atualmente, há aplicativos de celulares com perfis indicando a localização física de seus usuários (como o Grindr, o Scruff, o Hornet). A adesão foi tanta que os sites tradicionais com perfis de encontros se adaptaram à nova tecnologia, e criaram aplicativos próprios para celulares. As novas alternativas permitem a união de toda a mobilidade e flexibilidade do celular com o "acesso ao compartilhamento de informações em rede" (Leal, 2013, p. 12). 
A tendência a utilizar tais programas foi seguida, a posteriori, pelo público heterossexual, ao se criar aplicativos como o Tinder. Aplicativos para o público gay começaram a surgir por volta de 2009, mas somente três anos depois foi criado um específico para os heterossexuais (Versignassi \& Burgos, 2014). Apesar das características inerentes a cada um dos aplicativos, sua função é semelhante - apresentar perfis que possibilitam contato com outras pessoas que estejam nas proximidades (ou em outros locais de interesse).

Indubitavelmente, a possibilidade de contatos virtuais gerada pela rede mundial de computadores permite a ampliação efetiva da rede social de qualquer pessoa que tenha acesso a computadores ou celulares conectados. Foi apontada aqui a marcante influência das mídias sociais nas relações humanas, em especial no contexto da realidade brasileira nos últimos 17 anos. Esse processo resultou na possibilidade de geração e manutenção de vínculos relacionais, principalmente no grupo homoafetivo.

Nesse contexto, surgiu o interesse em investigar se e como o meio acadêmico está realizando estudos acerca dessa nova realidade social. É importante conhecer se e como a influência das mídias sociais vem sendo discutida em trabalhos referentes aos relacionamentos afetivos, em especial, aos relacionamentos homoafetivos.

\section{Revisão sistemática de conteúdo de artigos sobre relacionamentos virtuais}

A constatação da influência e do papel dos meios virtuais como veículos de aproximação e construção de vínculos na contemporaneidade mobilizou o interesse pela realização de uma revisão sistemática de conteúdo de artigos científicos. Trata-se de um tipo de investigação que procura reunir os assuntos e resultados de pesquisas já realizadas na área, podendo abranger dados estatísticos ou não. É um estudo retrospectivo e com delimitação definida (Cordeiro, A. M.; Oliveira, G. M. de; Rentería, J. M.; Guimarães, C. A., 2007; Schütz, G. R., Sant'Ana, A. S. S., \& Santos, S. G., 2011).

Esse método permite a agregação do material que já foi produzido em um determinado campo do conhecimento. Um de seus benefícios é apontar o estado da arte e prevenir a duplicação de estudos já realizados na área. Contribui também para apontar as controvérsias presentes na literatura. Outra contribuição importante das revisões sistemáticas de literatura é definir áreas passíveis de mais estudos. Desse modo 
economizam-se recursos e deixa-se claro as demandas para novas investigações (Atallah, N. A. \& Castro A. A., 1997).

Os critérios de inclusão e exclusão de artigos devem ser bem definidos, precedidos de um teste de relevância preliminar. Há que delimitar um período específico, idioma ou nacionalidade, além de perguntas que sejam centrais para o objeto do estudo. A utilização desse método demanda a leitura na íntegra dos artigos selecionados, para permitir a análise dos temas já estudados e ampliar a efetividade de estudos futuros (Pereira, A. L. \& Bachion, M. M., 2006).

A possibilidade de contatos virtuais gerada pela rede mundial de computadores e a ampliação efetiva da rede social de pessoas que têm acesso a computadores ou celulares conectados (repita-se) é um tema que merece ser pesquisado. A relevância do assunto é evidente. Trata-se de uma nova modalidade de relação - ou de novo aspecto das relações humanas - referente aos contatos afetivos mediados por mídias sociais. A imediatividade, facilidade de início ou término da comunicação e vínculos, a relativização de distâncias, o agrupamento de interesses são alguns dos temas que merecem atenção.

As relações homoafetivas, apesar de ainda constituírem uma minoria social, tem sido cada vez mais expostas pela mídia escrita e televisiva. Há um contraponto entre a violência e o preconceito historicamente existentes com relação ao público LGBTTT e uma ampliação significativa de direitos, mediante decisões administrativas e judiciais no país. A aceitação social ainda caminha a passos lentos, mas pode-se verificar conquistas de espaços e respeito.

O recorte que foi utilizado para a revisão de conteúdo abrange os periódicos que fazem parte das bases de dados Scielo e Pepsic, além do Google Academico (congressos e seminários). Foram consultados também os sites de revistas científicas voltadas para os estudos de gênero, e vinculadas a universidades brasileiras: Revista de Estudos Feministas, publicação da Universidade Federal de Santa Catarina, Cadernos Pagu, revista da Universidade Estadual de Campinas e, por fim, a revista Bagoas, editada pela Universidade Federal do Rio Grande do Norte.

Foram tomadas como referência as publicações dos últimos dez anos, ou seja, referentes ao período compreendido entre março de 2004 a março de 2014. Além da definição das Bases de Dados para revisão dos periódicos, e do período de publicação, outro critério de inclusão definido foi que os artigos deviam ter como foco as relações estritamente emocionais, amorosas ou sexuais. Foram pesquisados artigos em língua 
portuguesa, mas não só publicados no Brasil. Os descritores utilizados na busca agregam as diversas mídias com os tipos de relacionamento afetivos e foram apresentados na Tabela 1.

\section{Tabela 1: Descritores de Busca Bibliográfica}

\begin{tabular}{l}
\hline Homossexualidade e internet \\
\hline Homossexual e internet \\
\hline Gay e internet \\
\hline Gay e on line \\
\hline Gay e virtual \\
\hline Gay e mídias sociais \\
\hline Lésbica e internet \\
\hline Lésbica e on line \\
\hline Lésbica e virtual \\
\hline Lésbica e mídias sociais \\
\hline Relacionamento e homoafetivo \\
\hline Conjugalidade e homoafetiva \\
\hline Relacionamento e internet \\
\hline Relacionamento e on line \\
\hline Relacionamento e virtual \\
\hline Relacionamento e mídias sociais
\end{tabular}

Os artigos localizados por meio da pesquisa de revisão sistemática da literatura estão relacionados na Tabela 2. Foi organizada uma Tabela para mostrar os resultados encontrados em cada uma das bases de dados investigada. Após a síntese apresentada nas Tabelas elencaremos os artigos conforme a subtemática identificada em seus textos. Cada subtemática está classificada com uma letra do alfabeto e os títulos dos artigos identificados com a letra da subtemática seguida de um número cardinal.

Tabela 2: Resultado de Revisão sistemática no Scielo

\begin{tabular}{l|l|l}
\hline Ano Publicação & Artigo & Descritores \\
\hline 2007 & A epistemologia do armário & $\begin{array}{l}\text { Relacionamento e gay e } \\
\text { homoafetivo }\end{array}$ \\
\hline 2008 & $\begin{array}{l}\text { O amor pode ser virtual? O } \\
\text { relacionamento amoroso pela } \\
\text { Internet }\end{array}$ & Relacionamento e internet \\
\hline 2011 & $\begin{array}{l}\text { Juventude ciborgue e a transgressão } \\
\text { das fronteiras de gênero }\end{array}$ & Relacionamento e virtual \\
\hline 2013 & $\begin{array}{l}\text { "Armários de vidro" e "corpos-sem- } \\
\text { cabeça" na biossociabilidade gay } \\
\text { online }\end{array}$ & Relacionamento e gay e on line \\
\hline
\end{tabular}




\begin{tabular}{l|l|l}
\hline 2013 & $\begin{array}{l}\text { Caça aos homens disponíveis: } \\
\text { corpo, gênero e sexualidade na } \\
\text { biossociabilidade gay online }\end{array}$ & Relacionamento e gay e on line \\
\hline 2013 & $\begin{array}{l}\text { Machos e brothers: uma etnografia } \\
\text { sobre o armário em relações } \\
\text { homoeróticas masculinas criadas on } \\
\text { line }\end{array}$ & $\begin{array}{l}\text { Relacionamento e homossexual e } \\
\text { internet }\end{array}$ \\
\hline
\end{tabular}

Tabela 3: Resultado de Revisão sistemática no Pepsic

\begin{tabular}{l|l|lll}
\hline Ano Publicação & Artigo & Descritores & \\
\hline 2009 & $\begin{array}{l}\text { O amor caiu na rede: sobre a } \\
\text { procura de parceiro e a evolução de } \\
\text { vínculos amorosos na Internet }\end{array}$ & $\begin{array}{l}\text { Relacionamentos e virtuais e } \\
\text { internet }\end{array}$ \\
\hline 2009 & $\begin{array}{l}\text { Sobre a evolução de vínculos } \\
\text { conjugais originados na Internet; }\end{array}$ & $\begin{array}{l}\text { Relacionamentos e conjugalidade e } \\
\text { internet }\end{array}$ \\
\hline 2012 & $\begin{array}{l}\text { Algumas notas sobre as relações } \\
\text { humanas mediadas por } \\
\text { computadores }\end{array}$ & $\begin{array}{l}\text { Relacionamentos e virtuais e } \\
\text { internet }\end{array}$ \\
\hline
\end{tabular}

Tabela 4: Resultado de Revisão sistemática no Google Acadêmico (congressos e seminários)

\begin{tabular}{l|l|l}
\hline Ano Publicação & Artigo & Descritores \\
\hline 2006 & $\begin{array}{l}\text { Homossexualidade e subjetividade } \\
\text { on line: um estudo de comunidades } \\
\text { virtuais gays }\end{array}$ & Relacionamentos e gay e on line \\
\hline 2009 & $\begin{array}{l}\text { Juventude, homossexualidade e } \\
\text { mídia digital }\end{array}$ & $\begin{array}{l}\text { Relacionamentos, } \\
\text { homossexualidade e midias }\end{array}$ \\
\hline 2010 & $\begin{array}{l}\text { Do Ciberamor Romântico: } \\
\text { Representações Do @mor Num } \\
\text { Namoro Virtual }\end{array}$ & $\begin{array}{l}\text { Relacionamentos e virtuais e } \\
\text { internet }\end{array}$ \\
\hline 2013 & $\begin{array}{l}\text { Webgay \& Gaymobile: o fluxo da } \\
\text { homossexualidade em rede }\end{array}$ & Homossexualidade e on line \\
\hline 2013 & $\begin{array}{l}\text { Sexualidades e corporalidades } \\
\text { virtuais: uma análise dos } \\
\text { sujeitos homossexuais } \text { online }\end{array}$ & Homossexualidade e on line \\
\hline
\end{tabular}

a) Inibição e maior possibilidade de encontros em relacionamentos que começam de forma virtual: sete (7) artigos

a.1) Algumas notas sobre as relações humanas mediadas por computadores;

a.2) Do Ciberamor Romântico: Representações Do @mor Num Namoro Virtual; 
a.3) O amor caiu na rede: sobre a procura de parceiro e a evolução de vínculos amorosos na Internet;

a.4) A epistemologia do armário;

a.5) "Armários de vidro" e "corpos-sem-cabeça" na biossociabilidade gay online;

a.6) Caça aos homens disponíveis: corpo, gênero e sexualidade na biossociabilidade gay online;

a.7) Machos e brothers: uma etnografia sobre o armário em relações homoeróticas masculinas criadas on line;

b) Internet como facilitadora da narração de si para (a)o outra(o): oito (8) artigos b.1) Algumas notas sobre as relações humanas mediadas por computadores;

b.2) Do Ciberamor Romântico: Representações Do @mor Num Namoro Virtual;

b.3) O amor caiu na rede: sobre a procura de parceiro e a evolução de vínculos amorosos na Internet;

b.4) Sobre a evolução de vínculos conjugais originados na Internet;

b.5) $\mathrm{O}$ amor pode ser virtual? O relacionamento amoroso pela Internet;

b.6) Homossexualidade e subjetividade on line: um estudo de comunidades virtuais gays;

b.7) A epistemologia do armário;

b.8) Machos e brothers: uma etnografia sobre o armário em relações homoeróticas masculinas criadas on line;

c) A possibilidade de iniciar um relacionamento à revelia da distância: seis (6) artigos

c.1) Algumas notas sobre as relações humanas mediadas por computadores;

c.2) Do Ciberamor Romântico: Representações Do @mor Num Namoro Virtual;

c.3) $\mathrm{O}$ amor caiu na rede: sobre a procura de parceiro e a evolução de vínculos amorosos na Internet;

c.4) Sobre a evolução de vínculos conjugais originados na Internet;

c.5) $\mathrm{O}$ amor pode ser virtual? O relacionamento amoroso pela Internet;

c.6) Algumas notas sobre as relações humanas mediadas por computadores. 
d) A facilidade de encontro por afinidades comuns: oito (8) artigos

d.1) Do Ciberamor Romântico: Representações Do @mor Num Namoro Virtual;

d.2) Sobre a evolução de vínculos conjugais originados na Internet;

d.3) O amor pode ser virtual? O relacionamento amoroso pela Internet;

d.4) Juventude ciborgue e a transgressão das fronteiras de gênero;

d.5) Juventude, homossexualidade e mídia digital;

d.6) Homossexualidade e subjetividade on line: um estudo de comunidades virtuais gays.

d.7) A epistemologia do armário;

d.8) Webgay \& Gaymobile: o fluxo da homossexualidade em rede.

e) A Transposição de um relacionamento virtual para um relacionamento real:

e.1) Algumas notas sobre as relações humanas mediadas por computadores;

e.2) Do Ciberamor Romântico: Representações Do @ mor Num Namoro Virtual;

e.3) O amor caiu na rede: sobre a procura de parceiro e a evolução de vínculos amorosos na Internet;

e.4) Sobre a evolução de vínculos conjugais originados na Internet;

e.5) Machos e brothers: uma etnografia sobre o armário em relações homoeróticas masculinas criadas on line;

e.6) Webgay \& Gaymobile: o fluxo da homossexualidade em rede;

f) Fantasias, projeções e ilusões que podem ser criadas pela virtualidade: cinco (5) artigos

f.1) Algumas notas sobre as relações humanas mediadas por computadores;

f.2) Do Ciberamor Romântico: Representações Do @mor Num Namoro Virtual;

f.3) O amor caiu na rede: sobre a procura de parceiro e a evolução de vínculos amorosos na Internet;

f.4) Sobre a evolução de vínculos conjugais originados na Internet;

f.5) O amor pode ser virtual? O relacionamento amoroso pela Internet;

g) Autovalorização / Criação da própria identidade: três (3) artigos

g.1) Algumas notas sobre as relações humanas mediadas por computadores;

g.2) Homossexualidade e subjetividade on line: um estudo de comunidades virtuais gays; 
g.3) Webgay \& Gaymobile: o fluxo da homossexualidade em rede;

h) Gênero e heteronormatividade: nove (9) artigos

h.1) Juventude ciborgue e a transgressão das fronteiras de gênero;

h.2) Juventude, homossexualidade e mídia digital;

h.3) Homossexualidade e subjetividade on line: um estudo de comunidades virtuais gays;

h.4) Sexualidades e corporalidades virtuais: uma análise dos sujeitos homossexuais online;

h.5) A epistemologia do armário;

h.6) Machos e brothers: uma etnografia sobre o armário em relações homoeróticas masculinas criadas on line;

h.7) "Armários de vidro" e "corpos-sem-cabeça" na biossociabilidade gay online.

h.8) Caça aos homens disponíveis: corpo, gênero e sexualidade na biossociabilidade gay online.

h.9) Webgay \& Gaymobile: o fluxo da homossexualidade em rede;

i) Vantagens do anonimato: nove (9) artigos

i.1) Algumas notas sobre as relações humanas mediadas por computadores;

i.2) Do Ciberamor Romântico: Representações Do @mor Num Namoro Virtual;

i.3) O amor pode ser virtual? O relacionamento amoroso pela Internet;

i.4) Homossexualidade e subjetividade on line: um estudo de comunidades virtuais gays;

i.5) A epistemologia do armário;

i.6) Machos e brothers: uma etnografia sobre o armário em relações homoeróticas masculinas criadas on line;

i.7) Armários de vidro" e "corpos-sem-cabeça" na biossociabilidade gay online.

i.8) Caça aos homens disponíveis: corpo, gênero e sexualidade na biossociabilidade gay online.

i.9) Webgay \& Gaymobile: o fluxo da homossexualidade em rede; 
j) Identidades corporais (biossocialidade): cinco (5) artigos

j.1) Sexualidades e corporalidades virtuais: uma análise dos sujeitos homossexuais online;

j.2) Machos e brothers: uma etnografia sobre o armário em relações homoeróticas masculinas criadas on line;

j.3) "Armários de vidro" e "corpos-sem-cabeça" na biossociabilidade gay online;

j.4) Caça aos homens disponíveis: corpo, gênero e sexualidade na biossociabilidade gay online;

j.5) Webgay \& Gaymobile: o fluxo da homossexualidade em rede.

Alguns dos artigos abordam questões variadas de modo mais superficial, motivo pelo qual não fizeram parte da classificação e categorias apresentadas. Dentre as questões apontadas estão: o caráter terapêutico das relações virtuais; vícios que podem ser gerados pelo uso da internet; a criação de personagens (ou avatares) que não sejam correspondentes à realidade; e a falta de interesse de lésbicas em aplicativos para contato virtual. Outros temas podem ser identificados com a predominância de alguns aspectos, dependendo se o foco é uma relação heterossexual ou homoafetiva, como a elevação de autoestima, ampliação de redes sociais, o exercício da sexualidade.

Os artigos que abrangeram a temática de relações virtuais heterossexuais indicaram o uso das mídias sociais como um fator de aproximação, principalmente em virtude de inibições diversas, dificuldades de expressão de interesses e sentimentos, inadequações comportamentais. A virtualidade oportunizaria, portanto, um primeiro contato para identificação de possíveis afinidades de pensamento e de gostos que seriam primordiais para motivar a aproximação. Chama atenção a possibilidade desses aspectos de personalidade terem precedência sob aspectos físicos para ser dado início aos rituais de conquista.

Os artigos que trataram de temáticas referentes às relações virtuais homoafetivas enfocaram o culto ao corpo e a estereótipos heteronormativos (com relação aos gays). $\mathrm{O}$ esteriótipo de masculinidade é buscado pelos usuários - seja físico (biossocialidade) ou comportamental - e qualquer vinculação com o feminino (homens afeminados ou sexualmente passivos) é desvalorizada.

O culto ao corpo e à sexualidade transparecem nos artigos que estudaram o comportamento virtual dos gays. Os corpos são mostrados em partes - precipuamente 
os peitos, barrigas e pênis - ocultando-se os rostos. A virilidade é exposta mediante a exposição de atributos físicos mais vigorosos e másculos.

A biossocialidade é caracterizada como "os modos com que os usuários usam seus corpos na dinâmica social dos sites de relacionamento gays, e as maneiras com que eles se apropriam das possibilidades técnicas da internet como ferramentas para conhecer outros indivíduos" (Zago, 2013a, p. 421). Os artigos que abordam a biossocialidade deixam transparecer um preconceito baseado na heteronormatividade. Trata-se de um preconceito cruel, pois afeta e influencia as relações dos próprios homossexuais. Determinados seguimentos da comunidade gay procuram homens "com jeito de homem", "machos", "brothers", "viris".

Um reflexo dessa mentalidade é o surgimento do grupo denominado "g0ys" que passou a ser noticiado pela mídia brasileira no decorrer do ano de 2014. Os g0ys admitem contato afetivo e sexual com outros homens, mas sem a penetração anal, por ser considerada impura pelas religiões de origem judaico-cristãs. Valorizam o modelo do homem belo, másculo e forte, são homens que não querem se vincular à cultura gay, nem admitem ser classificados como tal (Wiik, 2012). Essa questão ainda não foi abordada de forma efetiva nos artigos científicos mais recentes,

No universo homoafetivo também transpareceu o medo da exposição da identidade do usuário e a autovalorização pessoal, em virtude de participação em grupos comuns, tanto envolvendo homens como mulheres. O receio da exposição estaria relacionado ao preconceito quanto à orientação sexual. Já a autovalorização permitiria a construção de uma identidade mais completa e estruturada, que contribui para fortalecer a autoestima dos membros dessas minorias sociais.

Algumas características foram citadas e abordadas de modo efetivo para ambos os públicos - heterossexual e homoafetivo: a perspectiva de transformar $o$ relacionamento virtual em real, mediante encontros físicos, "presenciais". Ademais, a facilidade de aproximação de pessoas por afinidades comuns apareceu para ambos os públicos.

Um aspecto que foi abordado como algo a ser verificado com prudência é a convergência entre a imagem e/ou personalidade divulgada no mundo virtual e a sua efetividade no mundo real. A internet e as diversas espécies de mídias sociais permitem a criação de personagens que podem não corresponder às expectativas geradas por quem tenha contato com a pessoa que está do outro lado do computador, tablet ou do telefone celular. 
As desconformidades entre o exposto na virtualidade e no "mundo real" tornaram-se tão usuais que geraram um filme e um seriado baseado neste filme, denominado "catfish", que atualmente é exibido pela MTv Brasil. O foco do seriado é promover o encontro de casais que durante meses somente tiveram contato virtual, mas não se conheceram pessoalmente. Geralmente, as surpresas não são das melhores, pois em várias situações não há correspondência entre o exposto virtualmente e as características físicas ou até de gênero das pessoas envolvidas.

As diferenças entre os artigos que tratam dos relacionamentos amorosos e virtualidade entre o público heterossexual e o homossexual são cristalinas. Pode-se afirmar que o foco das pesquisas envolvendo o público heterossexual é a dificuldade de aproximação física/real ou a possibilidade de aproximação permitida pela virtualidade, principalmente por afinidades comuns.

Já as pesquisas que investigam as relações mediadas pela virtualidade entre homossexuais, notadamente os masculinos, apresentam como resultados, precipuamente, vinculações a aspectos físicos e sexuais. Expõem questões nítidas de gênero e o preconceito que envolve padrões femininos.

Há pouca identificação ou discussão relativa à afetividade do homossexual masculino nas relações influenciadas ou geradas por mídias sociais. Parece que a afetividade continua sendo uma dimensão vinculada ao feminino, que permanece sendo desvalorizada e/ou invisibilizada, principalmente quando se trata da homossexualidade masculina.

De forma semelhante, as relações envolvendo lésbicas tampouco transparecem de forma efetiva, aspecto que foi ressaltado por Leal (2013). O autor questiona o motivo da inexistência de revistas homossexuais femininas, assim como a carência de sites e aplicativos homossexuais femininos.

Não houve localização de artigos abrangendo relações virtuais ou início de contato por mídias sociais de travestis, trangêneros ou transexuais. A invisibilidade do referido público, mais sujeito ainda a preconceito por parte da sociedade, permanece nos artigos científicos pesquisados.

Outro ponto interessante que transpareceu na revisão de conteúdo realizada foi a eventual caracterização da forma de contato virtual como uma espécie de gueto virtual. Seria uma forma de fuga do preconceito ou da violência relacionados à homofobia? Pelo contrário, o preconceito mais visível e relatado foi o proveniente dos próprios 
homossexuais masculinos, em virtude de uma misoginia que ainda é forte na cultura brasileira.

Por fim, essa revisão sistemática de literatura nos permitiu identificar também que há uma gama significativa de artigos e publicações envolvendo outros tipos de relação mediados por internet ou mídias sociais. Esses artigos faziam referências a grupos de profissionais, de consumidores etc, e foram excluídos do estudo.

\section{Do contato virtual à vida real: questões e desafios}

O presente trabalho gerou perguntas e uma proposta. Longe de comprovar o grau de efetividade da influência dos contatos realizados via internet para a construção do vínculo homoafetivo, pretende ser o ponto de partida para sua investigação.

Os canais, salas de bate papo e/ou perfis existentes na internet podem ter se constituído em um elo extremamente rico de contatos, de formação identitária e de grupo e de construção de vínculos afetivos. A experiência empírica com usuários dos programas existentes na internet aponta para o que pode ter sido uma das grandes revoluções em termos de relacionamentos homoafetivos - constituiu uma forma de nomear e reconhecer dimensões desses relacionamentos, antes invisibilizados e, portanto, ignorados.

Mais do que favorecer uma discussão sobre interações entre virtualidade e a construção de relacionamentos, sobre fantasias ou ilusões não correspondidas no mundo real, os artigos promoveram uma reflexão a respeito desse "sair do armário" virtual. Fica evidente a presença de aspectos positivos gerados por contatos intermediados por computadores, tablets ou smartfones para o grupo homoafetivo. Esse processo deve ser estudado de forma mais efetiva.

Lanço como hipótese que os canais de comunicação abertos, sem a necessidade de identificação prévia, mas com auto-caracterização através de apelidos, pela rede mundial de computadores, ou a criação de perfis nas redes sociais, também sem a referida identificação, permite novos contatos, diálogos, visibilidade e aceitação da homoafetividade como forma de relação possível. Oportuniza a passagem do segredo para a privacidade, gerando um espaço protegido, até certo ponto seguro, em que o controle dos limites do que pode ser dito ou exposto no ambiente virtual pode se generalizar para a vida real. 
Entrevistas com casais homoafetivos que tenham se conhecido através da rede mundial de computadores poderão oferecer elementos para a confirmação ou não dessa teoria, motivo pelo qual decidimos proceder à investigação do tema. A intenção é conceder visibilidade ao assunto e, eventualmente, reforçar a importância do acesso a contatos virtuais que oportunizem melhora na autoestima, autoimagem, autoafirmação sob a proteção da privacidade, e não sufocados por um temido segredo. Nesse contexto, acredita-se que a virtualidade possa ser vista como uma porta de acesso, como uma etapa na construção de vínculos afetivos reais e desejados por pessoas homoafetivas. 


\section{REFERÊNCIAS}

Araújo, M. F. (2009). Gênero e Família na construção de relações democráticas. In Casal e Família: permanências e rupturas; Casa do Psicólogo;

Atallah, N. A. \& Castro A. A. (1997). Revisões sistemáticas da literatura e metanálise: a melhor forma de evidência para tomada de decisão em saúde e a maneira mais rápida de atualização terapêutica. Diagnóstico \& Tratamento. v.2, n.2, p.12-15;

Brasil, Secretaria de Direitos Humanos do Governo Federal (2013). Relatório sobre a Violência Homofóbica no Brasil. Recuperado em 21 de maio de 2014, de http://www.sdh.gov.br/noticias/2013/junho/numero-de-denuncias-de-violenciahomofobica-cresceu-166-em-2012-diz-relatorio;

Campbell, U. (2014). Território Livre. Veja Brasília, ano 2, n. 8, 114 p.

Civiletti, M. V. P. \& Pereira, R. (2002). Pulsações contemporâneas do desejo: paixão e libido nas salas de bate-papo virtual. Psicologia Ciência e Profissão, Brasília, v. 22, n. 1, março 2002 . Recuperado em 03 de abril de 2014, de http://pepsic.bvsalud.org/scielo.php?script=sci_arttext\&pid=S1414-

98932002000100006\&lng=es\&nrm=iso;

Cordeiro, A. M.; Oliveira, G. M. de; Rentería, J. M.; Guimarães, C. A. (2007) Revisão sistemática: uma revisão narrativa. Rev. Col. Bras. Cir. vol. 34, n. 6. p.428-431.

Dela Coleta, A. S. M., Dela Coleta, M. F., \& Guimarães, J. L. (2008). O amor pode ser virtual? O relacionamento amoroso pela Internet. Psicologia em Estudo, 13(2), 277-285. Recuperado em 14 de março de 2014, de http://www.scielo.br/scielo.php?script=sci_arttext\&pid=S141373722008000200010\&lng=en\&tlng=pt. 10.1590/S1413-73722008000200010;

Donnamaria, C. P., \& Terzis, A. (2009a). O amor caiu na rede: sobre a procura de parceiro e a evolução de vínculos amorosos na Internet. Revista da SPAGESP, 10(2), 45-49. Recuperado em 28 de março de 2014, de http://pepsic.bvsalud.org/scielo.php?script=sci_arttext\&pid=S167729702009000200008\&lng=pt\&tlng=pt;

Donnamaria, C. P., \& Terzis, A. (2009b). Sobre a evolução de vínculos conjugais originados na Internet. Arquivos Brasileiros de Psicologia, v. 61, n. 3.

Donnamaria, C. P.; Terzis, A. (2012). Algumas notas sobre as relações humanas mediadas por computadores. Mental - ano X - no 18 - Barbacena-MG - jan./jun. 2012 p. 165-178. Recuperado em 25 de abril de 2014, de http://www.redalyc.org/articulo.oa?id=42025969009\#;

Féres-Carneiro, T. (2001). Casamento contemporâneo: construção da identidade conjugal. Casamento e Família: do social à clínica; NAU Editora, 145 p.; 
Junior, A. B. (2013). Sexualidades e corporalidades virtuais: uma análise dos sujeitos homossexuais online. VI Seminário de Estudos em Análise do Discurso. 1983 - 2013 Michel Pêcheux: 30 anos de uma presença; Universidade Federal do Rio Grande do Sul. Porto Alegre, de 15 a 18 de outubro de 2013. Recuperado em 28 de março de 2014, de http://www.ufrgs.br/analisedodiscurso/anaisdosead/6SEAD/SIMPOSIOS/Sexualidades ECorporalidadesVirtuais.pdf;

Leal, J. T. B. (2013). Webgay \& Gaymobile: o fluxo da homossexualidade em rede. $X$ POSCOM Seminário dos Alunos de Pós-Graduação em Comunicação Social da PUCRio 04, 05 e 06 de novembro de 2013. Recuperado em 04 de abril de 2014, de http://pucposcom-rj.com.br/wp-content/uploads/2013/11/Jorge-Tadeu-Borges-Leal.pdf;

Lopes, G.L, Luccas \& R., Teixeira, E.dA.,(2011). Um estudo sobre a história da internet no Brasil. Trabalho de conclusão do curso de bacharelado em Sistemas de Informação, Faculdade Alvorada, junho de 2011. Recuperado em 18 de maio de 2014, de http://pt.slideshare.net/darrochella/um-estudo-sobre-a-histria-da-internet-no-brasil\#;

Miskolsi, R. (2013). Machos e brothers: uma etnografia sobre o armário em relações homoeróticas masculinas criadas on line. Revista de Estudos Feministas, Florianópolis, 21(1): 424, janeiro-abril/2013. Recuperado em 02 de março de 2014, de https://periodicos.ufsc.br/index.php/ref/issue/view/2105;

Nussbaumer, G. M. (2005). Homossexualidade e subjetividade on line: um estudo de comunidades virtuais gays. ALCEU - v.6 - n.11 - p. 64 a 76 - jul./dez. 2005. Recuperado em 02 de março de 2014, de http://www.cult.ufba.br/Artigos/Gica.pdf;

Pereira, A. L. \& Bachion, M. M. (2006). Atualidades em revisão sistemática de literatura, critérios de força e grau de recomendação de evidência. Rev Gaúcha Enferm, Porto Alegre (RS) 27 (4): p.491-498.

Sales, S. R \& Paraíso, M. A. (2011). Juventude ciborgue e a transgressão das fronteiras de gênero. Revista Estudos Feministas, 19(2), 535-548. Recuperado em 28 de março de 2014, de http://www.scielo.br/scielo.php?script=sci_arttext\&pid=S0104026X2011000200015\&lng=pt\&tlng=pt. 10.1590/S0104-026X2011000200015;

Sanders, G. L. (2002). O amor que ousa declarar seu nome: do segredo à revelação nas afiliações de gays e lésbicas. Os segredos na Família e na Terapia Familiar; Artmed, 420 p.;

Schütz, G. R., Sant'Ana, A. S. S., \& Santos, S. G. (2011). Política de periódicos nacionais em Educação Física para estudos de revisão/sistemática. Revista Brasileira de Cineantropometria \& Desempenho Humano, 13(4), 313-319. Recuperado em 22 de março de 2014, de http://www.scielo.br/scielo.php?script=sci_arttext\&pid=S198000372011000400011\&lng=en\&tlng=pt. 10.5007/1980-0037.2011v13n4p313; 
Sedgwick, E. K. (2007). A epistemologia do armário. Cadernos Pagu, (28), 19-54. Recuperado em 23 de março de 2014, de http://www.scielo.br/scielo.php?script=sci_arttext\&pid=S010483332007000100003\&lng=en\&tlng=pt. 10.1590/S0104-83332007000100003;

Silva, V. V. A \& Takeuti, N. M. (2010). Do Ciberamor Romântico: Representações Do @mor Num Namoro Virtual. Trabalho apresentado no DT 05 - Comunicação Multimídia do IX Congresso de Ciências da Comunicação na Região Nordeste realizado de 10 a 12 de junho de 2010. Recuperado em 22 de abril de 2014, de http://www.intercom.org.br/papers/regionais/nordeste2010/resumos/R23-0317-1.pdf;

Versignassi, A. \& Burgos, P. (2014). Uma nova revolução sexual. Revista Superinteressante. Edição 328 - Janeiro de 2014.

Viega, S. (2014). Os 5 melhores aplicativos para conhecer lésbicas. Revista on line Umcomo. Recuperado em 01 de junho de 2014, de $\mathrm{http}$ ://relacoes.umcomo.com.br/articulo/os-5-melhores-aplicativos-para-conhecerlesbicas-3687.html;

Wiik, F. B. (2012). Os G0ys: Religião, Sexualidade, Gênero e Identidades Homoeróticas na Contemporaneidade. Psicología, Conocimiento y Sociedad, 66 - 83. Revista de la Facultad de Psicología, Universidad de La República, Uruguay. $\begin{array}{lllllll}\text { Recuperado em } 01 \text { de junho de } & 014 \text {, }\end{array}$ http://revista.psico.edu.uy/index.php/revpsicologia/article/view/138/74;

Zago, L. F. (2013a). "Armários de vidro" e "corpos-sem-cabeça" na biossociabilidade gay online. Interface - Comunicação, Saúde, Educação, 17(45), 419-432. Epub June 14, 2013. Recuperado em 28 de março de 2014, de http://www.scielo.br/scielo.php?script=sci_arttext\&pid=S141432832013000200014\&lng=en\&tlng=pt. 10.1590/S1414-32832013005000005;

Zago, L. F. (2013b). Caça aos homens disponíveis: corpo, gênero e sexualidade na biossociabilidade gay online. Sexualidad, Salud y Sociedad (Rio de Janeiro), (13), 8398. Recuperado em 28 de março de 2014, de http://www.scielo.br/scielo.php?script=sci_arttext\&pid=S198464872013000100005\&lng=en\&tlng=pt. 10.1590/S1984-64872013000100005; 


\title{
ARTIGO IV - INFLUÊNCIAS DA INTERNET E DE MÍDIAS SOCIAIS NA CONSTRUÇÃO DO VÍNCULO HOMOAFETIVO
}

\section{RESUMO}

O presente trabalho discute a relação entre o uso da internet e de outras mídias sociais e a construção e manutenção de relações homoafetivas. A reflexão tem como base uma pesquisa qualitativa com quatro casais homoafetivos que se conheceram pela internet, sendo dois casais masculinos e dois casais femininos. Aborda características da constituição desses novos modelos familiares. Os resultados chamam atenção para a multiplicidade e complexidade de fatores envolvidos nessas dinâmicas relacionais.

Palavras Chave: Conjugalidade; Homossexualidade; Internet; Mídias Sociais.

\begin{abstract}
This paper discusses the relationship between the usage of the internet and other types of social Medias in the construction and maintenance of homo-affective relations. The discussion is based on a qualitative research involving four homosexual couples that met each other through the Internet, being two males and two females. It addresses the characteristics of the constitution of these new models of families. The results call attention to the multiplicity and complexity of factors that are present in the dynamics of these relationships.
\end{abstract}

Keywords: Conjugality; Homosexuality; Internet; Social Medias.

\section{Família: "papai, mamãe, titia"?}

O momento atual é marcado por uma multiplicidade de formas de conjugalidade e de ser e viver em família. A mutabilidade da família e suas novas características são fatores de extrema importância para o entendimento dos vínculos afetivos. A associação entre conjugalidade, vida familiar e afetividade é recente. A família, da maneira compreendida no âmbito europeu ocidental, não possuía função afetiva até o século XVII. Sua finalidade principal era conservação dos bens e da linhagem. As trocas afetivas seriam realizadas fora do âmbito familiar, entre os vizinhos, amigos, amos, crianças, mulheres, homens.

\footnotetext{
${ }^{17}$ Trecho da música "Família" do grupo Titãs
} 
A partir da Revolução Industrial e do surgimento do capitalismo, a família passa a ser refúgio frente a um mundo competitivo e brutal. Adquire como algumas de suas principais características a privacidade e a intimidade. A família teve inicialmente uma função procriativa. Adquiriu, posteriormente, uma finalidade econômica, para se tornar por fim, um "refúgio afetivo" (Gomes, 1998).

No Brasil, no que se refere à família burguesa, a situação seria semelhante à da Europa. No período colonial, os casamentos nas famílias mais abastadas se baseavam em interesses familiares e nos benefícios econômicos e sociais que poderiam gerar. Fundavam-se, portanto, num contrato de intercâmbio de riquezas (Gomes, 1998), diferentemente do que ocorria com outras camadas, classes ou raças integrantes da população brasileira.

Com relação aos negros escravos, a violência e autoritarismo imposto, aliado a precariedade das condições de vida nas senzalas, acarretou uma associação dessas famílias à promiscuidade sexual e animalidade. Vale ressaltar, ainda, a situação dos índios, que também sofreram a imposição do domínio dos portugueses, processo que levou à descaracterização de suas formas de organização familiar, ao precisarem se adaptar ao modelo de família cristã (Diniz, 2005).

$\mathrm{Na}$ sociedade brasileira houve, portanto, diversos modelos familiares, que se entrecruzaram e sofreram influência mútua, no que tange à conjugalidade e à vida familiar. Esse processo resultou na ampla ocorrência de concubinatos, uniões esporádicas e da bastardia. As famílias estavam longe de ser homogêneas, ou seja, do que são consideradas atualmente e denominadas de "família tradicional" por setores religiosos de influência judaico-cristã na sociedade brasileira.

Giddens (2011) esclarece que na família tradicional, o casamento é considerado como um "estado da natureza", um estágio de vida em que se deve passar. As regras, normas, familiares, contudo, possuíam muito mais força, eram definidoras de conduta e geradora de representações sociais. Essa força apresenta-se mais relativizada nos dias de hoje.

Segundo Goldenberg (2001):

"Não existe muita clareza do que é considerado norma ou desvio nos relacionamentos conjugais. Ao mesmo tempo em que sobrevive, em cada um de nós, um modelo de família nuclear (pai-mãe e filhos), a realidade nos mostra inúmeras formas de relacionamentos afetivo-sexuais inimagináveis há poucos anos atrás."

Goldenberg (2001) reforça seu argumento citando Simone de Beauvoir, célebre feminista, que já criticava a instituição do casamento, considerando-o, desde a origem, uma 
instituição pervertida. Não poderia haver uma efetiva estabilidade no casamento previsto para toda uma vida, mas hipocrisia, mentira, hostilidade, infelicidade. A liberdade, sim, era o que geraria a transcendência, superação e expansão dos indivíduos.

As instituições, contudo, eram bem definidas e tinham seu papel inegável com relação à influência exercida nos membros da família ou casal. O futuro era mais "certo", bem como o lugar de cada um da família, seguindo-se a um pensamento patriarcal machista - homem provedor, mulher dona de casa, esposa, mãe, no máximo professora primária.

A partir do século XIX, ganha espaço uma visão higienista, em que a família se voltaria para o futuro e não para o passado. O compromisso passa a ser com os filhos, na busca por garantir uma boa saúde física e constituição moral. Os valores religiosos e patriarcais foram minorados e passou-se a valorizar de forma mais evidente o aspecto afetivo e sexual da relação conjugal (Gomes, 1998).

A família tradicional, segundo o modelo eurocêntrico, veio a se modificar novamente no decorrer do século XX. O modelo de produção econômica conjunta e funcional, baseado na manutenção de vínculos fortes com muitos parentes e todos participando de alguma forma da vida familiar, em que havia fortes conexões com a comunidade, cujos valores e moral tinham grande força, foi ultrapassado. As famílias tornaram-se mais individualistas, centradas nos sentimentos e afeição centrados no núcleo família, que ganhou várias conformações diferentes, mais flexíveis e igualitárias (Jablonski, 1998).

Novas formas de conjugalidade surgiram. A cerimônia do casamento se tornou uma formalidade, muitas pessoas preferem viver sozinhas ou sem a oficialização de uma união. A média de tempo das uniões diminuiu consideravelmente e os casamentos têm sido realizados mais tardiamente (Jablonski, 1998 e 2010). Há mais aceitação de relações amorosas que fogem da normalidade imposta, como as que apresentam diferenças consideráveis de idade, as que envolvem pessoas do mesmo sexo, de raças ou classes sociais diferentes, mas não de forma ampla.

Apesar da mudança na perspectiva do conceito de família em termos contemporâneos, alguns setores da sociedade ainda tentam engessar sua definição, inclusive em meios educacionais. Pesquisa realizada entre setembro de 2005 e maio de 2006, envolvendo o material didático fornecido a crianças de $1^{\mathrm{a}}$ a $4^{\mathrm{a}}$ série do ensino fundamental das escolas particulares da zona centro da cidade do Recife, analisou a representação de família implícita nos livros por elas utilizados. O material privilegiava um modelo hegemônico e tradicional, 
relegando outras configurações familiares a uma posição de inferioridade e evidente exclusão (Amazonas, M.C.L.A., Lima, A.O., Siqueira, D.F.C.C. \& Arruda, G. F., 2008).

A defesa às instituições como a família, principalmente com um viés religioso, ainda hoje é utilizada como motivação para a não validação de outras formas de conjugalidade ou concessão de direitos para aqueles que se propõem a vivenciá-las. Segundo o padrão social tradicional e heteronormativo, outras formas de união até seriam aceitáveis caso não ganhassem visibilidade. A ideia é que os desvios devem ser mantidos em segredo ou na privacidade do lar.

\section{Família e conjugalidade contemporâneas}

A família, sua definição e características estão mudando. Jablonski (1998, 2010) aponta que a adoção de uma abordagem sistêmica e complexa pode contribuir tanto para a interpretação do momento social vivido quanto para a compreensão de suas implicações no âmbito conjugal e familiar. A família tem se tornado mais nuclear e individualista.

Giddens (2011) e Jablonski (1998, 2010) ressaltam o papel dos feminismos e da ideia de igualdade entre homens e mulheres como grande agente transformador da família. Esse processo teve reflexos diretos na conjugalidade. Jablonski $(1998,2010)$ contudo, discute ainda a questão da frustração feminina por ter sido criada com papéis sociais definidos (boa mãe, esposa, responsável pelo lar e pela afetividade) e a busca pela independência, por autonomia, ocupação de lugares destacados na profissão de escolha.

As transformações da família não conseguem mais ser obstaculizadas pela força social da comunidade ou de instituições como Estado ou Igreja, uma vez que tais influências foram esvaecidas. Giddens (2011) as intitula de "instituições-casca" - aquelas que existem há muito tempo, com os mesmos nomes, mas não têm a força e conteúdo que possuíam no passado, tornando-se "inadequadas para as funções que são chamadas a desempenhar" (p. 28). Não mais determinam, de forma efetiva, os comportamentos familiares. As instituições tradicionais, portanto, perderam força e o controle social se tornou extremamente minorado.

O casamento poderia ser intitulado como "instituição-casca", tendo em vista que se reveste de cerimonial e simbologia tradicionais, com uma carga de significado tradicional, mas está inserido no que Giddens (2011) denomina de "risco fabricado". O conceito diz respeito ao fato dos nubentes não terem possibilidade de prever suas implicações, dadas as 
amplas mudanças que ocorreram tanto no casamento, como na família nos dias atuais, fator que gera insegurança.

A referida insegurança é bem exemplificada por pesquisa realizada por FeresCarneiro, Ziviani e Magalhães (2011). Os pesquisadores constataram que os relacionamentos conjugais atuais foram vistos "com características de superficialidade, efemeridade, descartabilidade, liberdade, hedonismo" e os relacionamentos antigos foram caracterizados por "maior compromisso, seriedade e duração" (Feres-Carneiro, Ziviani e Magalhães, 2011, p. 45/46).

Manter uma relação, atualmente, implica em desenvolver uma história compartilhada, com algum tipo de garantia intrínseca, implícita ou explícita, de que o relacionamento deva ser mantido, por gestos e palavras (Giddens, 2011). A união por dependência ou para atender a modelos de família pré-constituídos perderam força.

Ao deixarmos a forma tradicional de relacionamento afetivo-sexual para trás, não no sentido de considerá-la ultrapassada ou como "página virada", mas para se atentar à nova "normatividade" existente, é necessário refletir a respeito da troca da "segurança e estabilidade das relações antigas pela batalha permanente" (Goldenberg, 2001, p. 7). Tal visão, apresentada pela autora, é confirmada pela opinião das pessoas entrevistadas por FéresCarneiro, Ziviani e Magalhães (2011), no sentido da preocupação hedonística com o presente.

Os modelos de relacionamento, seja o casamento ou a família, devem ser reinventados constantemente. Nesta mesma linha, Diniz (2009, p. 142) afirma que: "A ruptura com o modelo tradicional de conjugalidade, a consequente flexibilização e abertura para explorar novos modelos relacionais parecem ser as características marcantes do modelo atual”. As formas de ser mulher e homem mudaram, estão plurais, diversificadas, complexas, como estão as relações e a sociedade.

A mudança atinge, não só as relações, como também os comportamentos sexuais, no âmbito da conjugalidade e fora dela. $\mathrm{O}$ que serve como parâmetro, modelo ou limite não são mais os dilemas morais. As referidas questões passam a ser interpretadas "como uma questão de bem-estar individual e social que remete às noções de saúde sexual e de comportamento responsável" (Bozon, 2004, p. 129).

Não haveria mais princípios absolutos e intocáveis, externos ao sujeito, seguindo a mesma ideia das "instituições casca", conceituadas por Giddens (2011), mas a discussão e renovação de contratos conjugais e sexuais. As regras a serem aplicadas nas relações devem ser objeto de negociação constante dentro do relacionamento (Bozon, 2004). 


\subsection{A homossexualidade e a conjugalidade homoafetiva}

As alterações com relação às características da família e às múltiplas formas de conjugalidade incluem a possibilidade de considerar as uniões entre homossexuais inseridas no conceito de conjugalidade. A inserção da afetividade do homossexual neste contexto, contudo, é lenta e progressiva, ou seja, passa por ciclos de aceitação e de rejeição. Tais ciclos dependem do contexto social, financeiro, do local e da época, apesar de terem ocorrido avanços evidentes em termos mundiais nos últimos anos.

A percepção do homossexual como diferente e marginalizado pela sociedade viria por volta do ano 1.700, algum tempo depois do Renascimento. Nessa época, teria havido uma "generalização da ideia de que todos os homens que faziam sexo com homens eram afeminados e todas as mulheres que desejavam outras mulheres eram masculinizadas e agressivas" (Araújo, 2005, p. 25).

A palavra "homossexual" teria surgido no tratado de John Addington Symond, de 1891, A Problem of Modern Ethics (Sanders, 2002, p. 225). Mais curioso, ainda, seria o surgimento e o significado inicial do termo "heterossexual":

No Medical Dictionary de Dorland (1901), "heterossexual" foi definido, com justiça poética inconsciente, como "apetite anormal ou pervertido pelo sexo oposto". Alguns diriam que sob o patriarcado tirânico, existe um sentido no qual toda a heterossexualidade masculina é um "apetite pervertido"...Mas não após o adendo de 1955 à terceira edição do Oxford English dictionary, heterossexual novamente precisou ser definido, e mesmo então isto ocorre com uma linguagem manifestadamente ideológica, como "pertencendo ou caracterizado pelas relações normais entre os sexos". Precisamos apenas refletir de passagem sobre a monstruosidade das relações entre os sexos, registrada em uma variedade imensa de estudos, para absorvermos o impacto deste uso de "normal".

É interessante perceber a mobilidade e os significados que as referidas palavras adquirem, conforme a época, momento social, contexto:

"o campo semântico da homossexualidade - e mais ainda do homossexualismo - e da "identidade homossexual" está constitutivamente marcado pelo contexto médico-patologizante que lhe deu origem na Europa da segunda metade do século XIX" (Melo, 2000, p. 199) 
A desmedicalização da homossexualidade, ou seja, sua retirada da Classificação Internacional de Doenças - CID, promoveu progressivo aumento da tolerância por parte da sociedade acerca das relações homoafetivas. Tais relações, entretanto, deveriam permanecer no âmbito privado, sem a proteção e reconhecimentos da legislação vigente. O problema, portanto, era a visibilidade (Arán e Corrêa, 2004). Contudo, para obtenção de seus direitos civis e penais, os homossexuais precisariam se tornar visíveis, o que implica em confrontar o padrão heteronormativo (Uziel et al, 2006). A pergunta que surte então é - mas a que custo?

Os exemplos de intolerância são muitos. Apenas para pontuar, cito o programa "CQC - Custe o que Custar", que abordou a questão da homossexualidade, em virtude da $16^{\text {a }}$ edição da Parada Gay, realizada no dia 10/06/2012, em São Paulo. Além de entrevistas realizadas na rua, em que algumas pessoas declararam preferir morrer a receber doação de sangue de homossexuais, foi apontada a existência da Portaria do Ministério da Saúde, de 2011, proibindo a doação de homossexuais masculinos que tiverem tido relações sexuais nos últimos 12 meses.

A proibição de doação de sangue por homossexuais contradiz a Portaria n. 1.353, também de 2011, do mesmo Ministério da Saúde, no sentido de que "a orientação sexual (heterossexualidade, bissexualidade, homossexualidade) não deve ser usada como critério para seleção de doadores de sangue, por não constituir risco em si própria" (art. $1^{\circ}, \S 5^{\circ}$ ). O referido entendimento lembra preceitos religiosos no sentido da ojeriza ao pecado e não ao pecador, que, nesses termos, não pode colocar em prática sua sexualidade.

Além dos exemplos já citados, cabe acrescentar que em 28 de junho de 2012 - dia mundial do orgulho gay, houve audiência pública para discussão do Projeto de Decreto Legislativo n. 234/2011, visando a sustação da Resolução n. 01/99, do Conselho Federal de Psicologia. Tal projeto estabelece normas de atuação para as(os) psicólogas(os) em relação à orientação sexual. A sessão foi marcada por discussões acaloradas no âmbito da Câmara dos Deputados. O mencionado Projeto de Lei foi objeto de repúdio por parte do Conselho Federal de Psicologia e foco de manifestações de diversas Organizações Sociais.

Ora, tais situações são apenas a ponta de um iceberg. Demonstram aspectos do preconceito que é vivenciado no dia a dia pelos homossexuais. A presença do preconceito é um fator que leva, muitas vezes, a uma negação da exposição de parte da própria identidade da pessoa, de forma a permitir uma convivência social mais pacífica ou menos limitada.

Os discursos heteronormativos trazem, paradoxalmente, a tirania da igualdade, ou seja, refletem a postura de que devemos ser mais similares do que diferentes. $\mathrm{O}$ amor teria como 
definidor de possibilidades nossos genitais, ao invés de nossas almas, e regras estariam acima dos afetos que movem os relacionamentos. Tais pensamentos deveriam ter menos força, atualmente, mas ainda apresentam-se com relativa frequência (Giddens, 2011).

Sanders (2002) informa que "inexiste uma experiência de vida mais tiranizada pelo segredo do que a de ser gay ou lésbica" (p. 223), que devem escolher entre a auto-afirmação ou a auto-anulação, caso haja conformismo à sociedade. Se optam pela auto-afirmação, provavelmente sofrerão de algum tipo de homofobia, direta e pessoal, ou indireta, através de piadas e de atitudes e falas de desvalorização/desqualificação.

O segredo referente à própria sexualidade seria venenoso, por anular um elemento de extrema relevância da pessoa homossexual. Sanders (2002) reflete sobre essa questão:

"Ser gay ou lésbica em uma cultura homofóbica e heterossexista pode amparar um segredo sobremaneira potente e deletério. Este não é apenas um segredo sobre um fato, um evento, é o acobertamento da essência de uma pessoa, daquilo que convida esta pessoa a juntar-se à raça humana - a necessidade para afiliar-se, embora com pessoas do mesmo sexo. É a busca por congruência entre uma necessidade interna e uma oportunidade valorizada, que gays e lésbicas experienciam. Esta congruência é considerada tão natural a ponto de ser ignorada, por pessoas heterossexualmente orientadas, mas com frequência é negada aos gays e lésbicas, se eles/elas sucumbem aos convites do segredo para anular sua singularidade individual - a capacidade para amar e aprender com esse amor." (p. 242)

A transição pode ser saudável para aqueles que não desejam se expor, ou sair do armário: a passagem do segredo para a privacidade. Os homossexuais escolheriam aqueles a quem se exporão, garantindo sua socialização, aceitação e sensação de pertencimento a determinado grupo. Outras pessoas ficariam à margem da situação, pessoas estas que poderiam, eventualmente, causar algum prejuízo pessoal ou profissional, em virtude do preconceito (Sanders, 2002).

A conjugalidade homoafetiva insere-se nesta situação, uma vez que costuma se tornar visível apenas para a família e amigos próximos do casal, ou, por outro lado, quando atinge uma conotação política, onde a visibilidade é relevante para a luta pelos direitos homossexuais. Em contextos mais amplos, para a família estendida ou na área profissional, torna-se um não-dito.

A possibilidade de casamento, reprodução ou educação das crianças continua sendo tema polêmico, apesar de cada vez mais aceito, em virtude das recentes discussões na mídia e 
de decisões judiciais. O Supremo Tribunal Federal ${ }^{18}$ considera as uniões estáveis homoafetivas possíveis, o que influenciou a aprovação da Resolução n. 175, de 14 de maio de 2013, do Conselho Nacional de Justiça, estabelecendo a obrigatoriedade de registro de casamento homoafetivo ou união civil homoafetiva por cartórios públicos.

Ainda com relação a direitos destinados a pessoas em relações homoafetivas, há orientações administrativas no sentido de conceder benefícios previdenciários e isenções de impostos mediante declarações de uniões estáveis, hetero ou homossexuais ${ }^{19}$. Hoje em dia existe maior possibilidade e aceitação para que casais homoafetivos possam adotar filhos.

Difícil, contudo, é estabelecer um padrão ou normatividade com relação aos casais homossexuais. A constante reinvenção e redefinição dos relacionamentos, hoje preocupação dos casais heteroafetivos, já era comum aos casais homoafetivos, em virtude da ausência de uma normatividade social referente às posturas exigidas a um casal heteroafetivo (FéresCarneiro e Ziviani, 2009, p. 88):

"[...] como não há modelos culturais, rituais ou normas disponíveis, como exemplos para a integração de casais do mesmo sexo à família, estes casais têm de inventar seus próprios "rituais de pertencimento", que servirão para fortalecer e validar a sensação de ser um membro da família" [...] Nessa perspectiva, Arán e Corrêa (2004) apontam para a mudança nas representações, nas práticas e nas identidades sexuais que vêm ocorrendo na contemporaneidade. Afirmam que os fatores principais para tal fenômeno são: a crise na família nuclear (monogâmica e heterossexual), a entrada da mulher no mercado de trabalho, a separação da sexualidade da reprodução e uma política de visibilidade da homossexualidade. Em tal contexto, o debate sobre o reconhecimento social e jurídico de casais homossexuais tem sido um dos fatores de destaque."

Vários fatores/processos sociais contribuíram para enfraquecer a noção de "normalidade sexual" (Bozon, 2004, p. 103). Os debates em torno das parcerias civis do mesmo sexo e o aumento da visibilidade da homossexualidade - o que pode ser confirmado nas telenovelas dos últimos dez anos, assim como em outras fontes de informação - jornais, revistas, talk shows, foram fontes de reflexão. As paradas gays, em especial a de São Paulo, que é uma das mais famosas e frequentadas no mundo, foi importante para a redefinição do conceito de casal.

\footnotetext{
${ }^{18}$ STF - Arguição de Descumprimento de Preceito Fundamental n 132/RJ, Tribunal Pleno, Rel. Min. Ayres Brito, DJe 14/10/2011;

${ }^{19}$ Instrução Normativa INSS/PRES no 45 , de 6 de Agosto de 2010 - DOU de 11/08/2010.
} 
A epidemia de AIDS (Uziel et al, 2006), que demandou campanhas de prevenção do Governo, teve um papel político e social importante. Se por um lado, contribuiu para uma maior segregação e preconceito, por outro permitiu que a sexualidade homossexual e as relações homoafetivas fossem mais discutidas. Oportunizou a atenção da mídia e da sociedade para outras formas de conjugalidade, também existentes no seio da comunidade LGBTTT. Produziu campanhas que foram fundamentais para ampliação dos cuidados referentes às práticas sexuais, independente da opção sexual.

Há ainda um fator que merece destaque como promotor da visibilidade homossexual: a percepção dos interesses comuns e inerentes a este grupo que tem inclusive reflexos econômicos. Ao longo dos anos surgiram revistas próprias, sites, agências de turismo, cruzeiros destinados para esse grupo que costuma gastar mais que os heterossexuais, de forma geral. O dinheiro do referido público ganhou denominação própria - "pink money", conforme reportagem da revista IstoéDinheiro, intitulada "o poderoso mercado gay", publicada em 21 de junho de 2006.

Apesar do enfraquecimento da ideia de normalidade heteronormativa, os homossexuais ainda tendem a se agrupar e a criar uma noção de coletividade através de locais que os aceitem e respeitem (Araujo, 2005). Seja na "vida real", seja na virtualidade, essa necessidade de formar comunidades próprias permanece em função dos preconceitos explícitos e implícitos. A virtualidade, em especial, a internet e as mídias sociais tem uma função importante na construção dos relacionamentos homoafetivos.

\section{A influência da internet na construção da conjugalidade homoafetiva}

A influência da internet tem sido discutida em trabalhos referentes à conjugalidade heterossexual (Dela Coleta, A. S. M., Dela Coleta, M. F., \& Guimarães, J. L., 2008; Donnamaria, C. P., \& Terzis, A, 2009a, 2009b, 2012). Tais abordagens costumam ressaltar a internet como fator de aproximação física para casais que estejam distantes um do outro ou para pessoas que compartilhem interesses similares. A internet pode atuar também como agente que afasta o casal, em virtude de eventuais "traições virtuais" ou por provocar a falta de um maior convívio pessoal.

Diferente da conjugalidade heterossexual, um fator permanece a parte dos estudos que abrangem os hábitos, a força política, a visibilidade ou a afetividade homossexual: a 
influência das mídias sociais. Há que se ressaltar, contudo, a possibilidade da internet servir como facilitadora na construção de vínculos afetivos para casais homossexuais. A academia e a sociedade estariam atentas a essa nova forma de contato e sua influência na conjugalidade homoafetiva?

A concepção de identidade do sujeito pós-moderno "encontra nas salas de bate-papo virtuais um ambiente propício, onde o sujeito pode ser aquilo que desejar, inclusive ele próprio, desde que o contexto seja conveniente" (Civiletti e Pereira, 2002). Ora, a privacidade que a internet oferece permite o contato de pessoas de forma virtual, sem identificação, exposição ou necessidade de submissão a comportamentos preconceituosos (Sanders, 2002; Sedgwick, 2007; Zago, 2013a, 2013b).

A natureza interativa do ciberespaço oferece oportunidade de igualdade (pela possibilidade de não identificação das características físicas dos indivíduos que ali conversam) e sedução, em virtude da imaginação e disponibilidade de quem interage no ciberespaço (Araujo, 2009). Tais situações poderiam perdurar indefinidamente, com trocas de intimidade, fidelidade, privacidade, mesmo que virtuais, ou se transformar em relações pessoais e físicas.

Ressalte-se que, mesmo com a necessidade de fornecimento de alguns dados pessoais ou e-mail para cadastro nas redes sociais, sempre houve possibilidade de criação de perfis que não fossem suficientes para a identificação efetiva do usuário. Muitas vezes, são criados com fotos de paisagens ou de partes do corpo, contanto que não contenham nudez ou conteúdo erótico.

Sites com propostas de realizar contatos eminentemente homoafetivos surgiram. O Disponível, Manhunt, Gaydar, dentre vários outros, oferecem à/ao usuária/o a oportunidade de criar um perfil, contendo descrições físicas, gostos, objetivos, afinidades, fotos ou filmes. Abrangem propostas das mais românticas até sugestões de encontros para sexo casual e apresentam cunho visivelmente mais erótico, permitindo que seus usuários exponham fotos com nudez ou sexo.

$\mathrm{O}$ acesso aos sites mencionados costuma ser majoritariamente masculino, o que confirma o estereótipo construído da "importância dada pelos homens aos atributos físicos beleza, jovialidade - e à atração física em suas escolhas amorosas" (Féres-Carneiro, 2001, p. 72). Outro fator talvez seja pelas características inerentes aos sites, como a exposição de fotos sensuais. Foi só recentemente que surgiram outras mídias sociais voltadas estritamente ao público feminino, como o LesbianPersonals, dentre outros (Viega, 2014), mas com o foco 
voltado à relações afetivas e não à sexualidade em si, o que confirma outro estereótipo relacionado a gênero - mulher é mais afetiva, o homem é mais visual/sexual.

Outra novidade relativamente recente foi a de que os aparelhos celulares podem ser munidos com aplicativos de programas para contatos. Através de perfis elaborados pelas/os usuárias/os, à semelhança dos sites já citados, o celular permite o acréscimo do georeferenciamento, ou seja, as/os usuárias/os tem acesso à distância física que se encontram um/a do/a outro/a. Alguns exemplos são o Grindr e o Scruff (para o público homossexual masculino), ou o Brenda (para o público homossexual feminino) que geram mais uma oportunidade de encontros reais.

A possibilidade de contatos virtuais, e agora também de encontros reais, gerada pela rede mundial de computadores e de celulares permite, indubitavelmente, a ampliação efetiva da rede social de qualquer pessoa que tenha acesso a computadores ou celulares conectados. Fica evidente, portanto, a marcante influência da internet e mídias sociais nas relações humanas, em especial dentro da realidade brasileira nos últimos vinte anos. É clara a possibilidade de geração e manutenção de vínculos relacionais mediados pela tecnologia, principalmente no contexto homoafetivo.

\section{O que elas e eles dizem? Uma análise de conteúdo de entrevistas com casais homoafetivos}

O objetivo dessa pesquisa qualitativa foi conhecer a influência do uso de recursos da internet na construção do vínculo entre casais homoafetivos. Um questionário semiestruturado foi utilizado. As perguntas buscaram identificar elementos relativos às influências das mídias sociais na construção e manutenção dos respectivos relacionamentos.

As entrevistas foram realizadas de forma presencial e cada um dos casais entrevistado em conjunto. Uma das entrevistas foi realizada em ambiente público, em um restaurante da cidade, em virtude da dificuldade de agenda com o casal. As demais entrevistas foram realizadas em locais privados, em residências dos casais ou do pesquisador.

As/Os participantes foram quatro (4) casais que moram juntos e se conheceram pela internet, sendo dois (2) casais de mulheres e dois (2) casais de homens, escolhidos mediante amostra de conveniência. Todos possuem um alto nível socioeconômico, com rendimento familiar acima de $\mathrm{R} \$ 10.000,00$ (dez mil reais). 
Regina (nome real, 45 anos) tem graduação em direito e sua companheira Dulcinéia (nome real, 34 anos), que prefere ser chamada de Néia, tem segundo grau completo, além de ser técnica em enfermagem.

Andreia (nome fictício, 48 anos) é graduada em letras e mestranda na mesma área, casada em cartório com Patrícia (nome fictício, 51 anos), graduada em administração de empresas.

Paulo (nome fictício, 30 anos) é formado em arquitetura e urbanismo, mestrando na mesma área, é companheiro de Henrique (nome fictício, 34 anos), que possui graduação em geografia e pós-graduação em meio ambiente.

Rogério (nome real, 43 anos) é graduado em engenharia elétrica, é companheiro de Andre (nome fictício, 23 anos), graduado em fisioterapia. Ambos com casamento em cartório programado para janeiro de 2015.

Alguns dos nomes são fictícios, atendendo ao desejo das(os) participantes de não identificação. Contudo, alguns nomes reais foram citados, em virtude da visibilidade buscada pela influencia da teoria queer. A teoria queer tem como uma de suas principais bandeiras a questão da visibilidade homossexual. Por um lado, busca aceitação da pluralidade sexual, por outro, visa combater ataques que comumente acontecem à comunidade LGBTTT por setores tradicionais da sociedade, na defesa de valores da "família tradicional" (Louro, 2001; Arán \& Correa, 2004; Uziel et al, 2006).

O conteúdo das respostas foi analisado conforme categorias temáticas de acordo com o critério semântico apresentado por Bardin (2011). A sistematização das respostas às perguntas foi realizada intuitivamente, através da leitura flutuante. Os resultados significativos foram listados, mesmo que não constantes nas perguntas de forma expressa.

O critério semântico permitiu uma análise temática transversal, recortando "o conjunto das entrevistas por meio de uma grade de categorias projetada sobre os conteúdos" (Bardin, 2011, p. 222). Observou-se a frequência dos temas extraídos do conjunto dos discursos, permitindo a comparação dos dados obtidos através das entrevistas com dados de textos com temática relacionada, além de entrevistas realizadas em outros trabalhos científicos. Temas semelhantes foram agregados, além de informações implícitas extraídas de determinados respostas, conforme exposto na Tabela 1 e temas abaixo especificados. 
Tabela 1 - Frequência dentro de cada tema

\section{Aspectos da Conjugalidade homoafetiva e sua relação com mídias sociais}

\begin{tabular}{l|c|c}
\hline Temas & F. & $\%$ \\
\hline a) Auto nomeação como homossexual & 8 & 100 \\
\hline b) História de dificuldade na aceitação da própria homossexualidade & 7 & 88 \\
\hline c) Consideram-se assumidas(os) atualmente & 8 & 100 \\
\hline d) Homofobia ou preconceito na família & 5 & 50 \\
\hline e) Homofobia ou preconceito no trabalho & 2 & 25 \\
\hline f) Homofobia ou preconceito sofrido por desconhecidas(os) & 2 & 25 \\
\hline g) Preconceito dentre os próprios homossexuais & 2 & 25 \\
\hline h) Uso de mídias sociais como mais um meio de contato & 8 & 100 \\
\hline i) Busca inicial por relacionamento & 4 & 50 \\
\hline j) Busca inicial por sexo & 4 & 50 \\
\hline k) Problemas levantados no que se refere ao uso das mídias sociais & 4 & 50 \\
\hline l) Consideram-se um casal & 7 & 88 \\
\hline m) São casadas em cartório & 2 & 25 \\
\hline n) Representação social: Homens demoram a se comprometer & 8 & 100 \\
\hline o) Representação social: Mulheres se comprometem rapidamente & 6 & 75 \\
\hline p) Participam de ONGs ou movimentos sociais ligados à causa & 0 & 0 \\
LGBTTT & & \\
\hline
\end{tabular}

Cada um dos temas será explorado a seguir:

a) Auto nomeação como homossexual

Tema relacionado à classificação apresentada pelos próprios casais, referente à sua orientação sexual. Todas e todos foram enfáticas(os) em afirmar sua homossexualidade:

$$
\begin{aligned}
& \text { "Homossexual, com certeza!” (Regina) } \\
& \text { "Homossexual! (Paulo e Henrique) }
\end{aligned}
$$

b) História de dificuldade na aceitação da própria homossexualidade

Tema que aponta dificuldades enfrentadas entre as/os entrevistadas(os) para assumir a homossexualidade no decorrer do seu desenvolvimento/descoberta sexual:

"Foi muito difícil pra mim. Porque eu venho de uma família evangélica e desde criança eu sou homossexual, desde criança. Desde que eu me entendo por gente, desde os 5, 6 anos que eu me entendo por gente, eu sou. E a minha família nunca me apoiou. Foi assim um pouco difícil, pra não dizer o contrário, foi muito difícil pra mim. Porque a minha mãe sempre dizia que eu era estranha em casa, entranha, estranha, estranha...diferente das minhas irmãs, o meu comportamento. Mas eu nunca falava nada." (Neia) 
"Eu tenho lembranças desde os 10, 11 anos, de sempre sentir atração por homens. Mas era uma coisa velada, sei lá...vai passar...uma coisa normal. E...mas...acho que a partir de uns 15, 16 eu vi que era isso mesmo, comecei a entender melhor o que era aquilo... essa atração e é isso." (Paulo)

c) Consideram-se assumidas(os) atualmente

Tema relacionado ao fato das(os) entrevistadas(os) assumirem sua sexualidade perante a sociedade. Observou-se que não há uma iniciativa própria para a demonstração da homossexualidade, mas todas(os) se identificariam caso fossem questionados em alguma situação relevante. Houve restrições levantadas quanto ao ambiente de trabalho:

"Não. Todo mundo sabe. (pausa) Eu confesso a você que eu tenho um pouquinho de receio com relação a cliente. Eu tenho um cliente que é empresa, tanto que eu saí do facebook recente, mas eu tava no facebook até pouco tempo atrás, e ela (Neia) me adicionou, marcou meu nome, colocou "relacionamento sério" e marcou meu nome. E eu não confirmei. E eu expliquei pra ela porque eu não confirmei. Não pelas pessoas em geral, não tenho nenhum problema com isso. Eu acho que todo mundo ao redor sabe. Mas eu fico com medo de um cliente específico que eu tenho. Eu tenho medo desse cliente me discriminar por isso.” (Regina)

Sim...com algumas restrições em vários ambientes. Trabalho, especificamente. (Patricia)

"Ele trabalha comigo. Então, no trabalho a gente é bem assumido. É tranquilo." (Rogério)

d) Homofobia ou preconceito na família

Tema que descreve atitudes preconceituosas ou homofobia sofridas no âmbito familiar:

"E quando eu fiz meus 18 anos eu contei e foi uma situação bem complicada. Eu esperava ser espancada (risos). Graças a Deus, fisicamente não, mas moralmente sim, porque a situação que eu expus para eles da minha vida não foi boa pra eles, como também não foi boa pra mim. A minha mãe me agrediu com palavras, o meu pai chorou muito. Mas 3 dias depois ela me mandou embora de casa e nunca mais eu voltei (mostrando certa emoção)." (Neia)

"Então assim, é isso...é uma dificuldade geracional. Minha mãe, hoje em dia, tá com 85 anos de idade. Eu vou assumir que sou lésbica já to com quase 30 anos. E a cabeça da mamãe levou um tempo. Pra 
entender, aceitar. E mamãe, volta e meia, chama a Andrea de "a sua amiga". Eu falo: - Mamãe, ela não é minha amiga. Eu casei! Você foi no meu casamentooooo!" (Patricia)

"Meu pai disse uma vez, disse: - Olha, eu não entendo, não compreendo...é...mas pra mim só me importa que você seja feliz. Se você estiver feliz, você vai ser sempre meu filho, vai ter sempre o meu apoio. Então, meu pai ele tenta participar, ele inclusive ele, ele e minha sogra já conversaram sobre algumas coisas, já...: - Como foi que você soube? - já...trocaram essa experiência, achei bem divertido (risos). Mas a minha mãe, ela disse que não aceita e não vai aceitar nunca. Então ela ignora o fato, ela faz de louca, assim, né..." (Paulo)

e) Homofobia ou preconceito no trabalho

Tema que abrange eventual homofobia ou preconceitos sofridos no trabalho pelas(os) entrevistadas(os):

"Um colega meu que ficou sabendo que eu tive uma namorada e contou pra ela. Conhecia minha ex-namorada e contou pra ela. - Sabia que ela é gay? Não sei o que...- Ela no outro dia, ela mudou totalmente comigo." (Neia)

"Continuando a parte do preconceito, eu acho que teve uma parte assim que desconfio que seja. $\mathrm{Na}$ época em que fiz estágio, que fiz estágio em um (...), é...eu lembro que eles tinham medo de mim. Os preceptores do estágio, eles tinham medo de ficar sozinhos comigo na sala, porque eles já sabiam que eu era gay, porque uma preceptora me conhecia de um estágio anterior, era namorada de um colega que tinha comentado, eles sabiam e eu não escondia, não. Eles ficavam desconfortáveis perto de mim, porque eles eram militares, bem machistas, assim...aí eu via que eles ficavam desconfortáveis.” (Lucas)

f) Homofobia ou preconceito sofrido por desconhecidos

Tema que aborda eventuais discriminações sofridas pelas(os) entrevistadas(os) por desconhecidos:

"Isso eu tive no meu início de vida. Assim, de ta andando na rua, meio de mão dada com a namorada e a gente perceber uma confusão atrás e ver três caras correndo atrás da gente, tacando copo, tacando garrafa...tivemos que sair correndo. Mas isso foi, sei lá, na década de 80.” (Andrea)

"É...fui atacado por skinheads (risos)...eu estava saindo da boate com meus amigos...foi um momento traumático. Foi um pouco antes de conhecer ele. Não foi legal.” (Henrique) 
g) Preconceito dentre os próprios homossexuais

Tema que enfoca eventuais preconceitos sofridos no próprio meio homossexual. Somente foi apontado por dois participantes, do sexo masculino:

"Ele é gay, mas não conhece aquele menino, ou às vezes, nunca viu com aquele olhar. Tem até uma página que eu sigo no facebook, eu gosto de compartilhar as coisas que publicam, porque eu gosto da visão que eles tem, que é "Os Entendidos". Eu sempre compartilho porque, porque eles falam muito do preconceito entre os próprios gays. Que eu acho que é assim, eu acho que você tem que mudar de dentro, pra conseguir mudar a visão. Porque se entre os próprios gays tem os preconceitos do jeito que tem, a gente tem que tentar mudar." (Lucas)

"O gay que você encontra na sauna você não pode namorar, porque é safado. Mas você ta querendo namorar e encontrou ele na sauna, você também tava na sauna. Então, existe...é a mesma coisa que acontece com as mulheres, mesma coisa que acontece com as mulheres com relação aos homens: - Aquele homem é muito safado! - Então...existe muita sexualidade reprimida, e lógico que isso tudo implica em tudo isso.” (Rogerio)

h) Uso de mídias sociais como mais um meio de contato

Tema relacionado ao advento das mídias sociais como uma opção a mais para conhecer ou manter contato com pessoas:

$\mathrm{E}$ as pessoas estão mais corajosas atrás da máquina do que pessoalmente. Até hoje eu acho que é assim. Você vai na boate, que não é um ambiente propício pra conhecer pessoas, não é um lugar que você vai pra conhecer. Você vai pra ficar ou pra dançar. Você chega da boate, na hora que você pega o facebook de alguém lá, aí, a partir dali, depois dali, alguma coisa pode acontecer. Então você vai lá: - Qual o seu facebook? Então tá, tá anotado aqui. - E continua na balada. No dia seguinte, as coisas podem acontecer a partir de uma troca de whatsapp, de uma troca de facebook. Eu acho que hoje está funcionando muito bem. E acho que não tem volta esse caminho mais não. Essa...a nova geração, principalmente, que tá chegando...é isso aí. (Regina)

"É isso, a questão do envolvimento mediado por tecnologia, a impressão que a gente sempre teve naquele...que ficou muito claro pra gente, é que foi uma...foi um recurso de alta intimidade. A gente, pela restrição do contato, a gente só conseguiu - e isso nos interessava - ter muita intimidade. Tinha que ser muita coisa pessoal ou íntima sendo conversada, logo nos primeiros encontros. Coisas que as pessoas podem levar 3 meses pra contar, a gente tava contando na segunda semana. Porque tinha que manter aquela coisa viva. Como vou manter essa coisa viva dizendo nada? A privação sensorial, também. Assim, quando você ve, você se distrai. Quando você pega na mão, você se distrai. Quando você transa, você se distrai! Nos momentos, quando você janta...tem 
uma distração. E que não existe num negócio com a palavra. Palavra escrita." (Patricia)

"UOL não tinha na minha cidade. Era chat do terra e...conheci pessoas...às vezes entrava na sala "imagens" e conhecia pessoas...conheci pessoas do Brasil inteiro. Inclusive, há um mês atrás, uma pessoa que eu conheci naquela época...isso deve fazer 14 anos ou mais, e a gente esporadicamente tinha algum contato...mas a gente conversava muito na época, éramos amigos de internet...e eu reencontrei aqui perto, a gente se voltou a falar.” (Paulo)

Não vejo nada ruim. É igual a que eu falei. Permite a gente conversar com mais pessoas, ter mais contato, trocar mais ideia...assim, você fala...tem preconceito, mas preconceito tem em qualquer lugar. Lá você só tem acesso a mais gente com preconceito e se tem um debate que não acaba em sangue, pelo menos. Talvez, se eu tivesse num debate com muitas pessoas que eu converso lá ao vivo, talvez eu saísse ferido desses debates. Então, eu acho muito bom. Eu acho perfeito. Eu uso pro meu trabalho, uso pra vender imóvel, uso pra dar aula...eu, sinceramente...meus alunos, eu tenho contato, tiro dúvidas, eles falam comigo...eu me dou muito bem com mídias sociais. Não vejo problemas. Só acho que ela amplia muito as possibilidades. Só vejo isso, não vejo...(Rogerio)

i) Busca inicial por relacionamento

Tema relacionado com o acesso às mídias sociais com a intenção de conhecer outras pessoas para possibilidade de relacionamento amoroso. Nesse tópico, tal objetivo não apareceu entre os homens, mas as mulheres foram unânimes com relação à tal finalidade:

Eu também tava separada, lá em Vitória. E também já tava querendo uma pessoa pra mim. E quando ela visualizou meu perfil, eu entrei no perfil dela, também, e mandei uma mensagem pra ela. Ela me adicionou no Skype e a gente começou a conversar...e dentro de um mês que a gente tava conversando eu disse pra ela que eu vinha pra cá. Aí eu fiz de tudo, comprei a passagem, setembro, outubro...um mês..." (Neia)

"Não...a gente se conheceu no início de dezembro de 98. Aí, assim, a gente se esbarrou num site, a gente se esbarrou no chat, e tava rolando uma imbecilidade muito grande, e ela cujo nick era "claraluz" e ela fez um comentário muito bom! Era um comentário que eu não lembro o que era...já fiz muito esforço pra tentar lembrar, mas assim, era um comentário adequado, mas sacana, debochado, é...meio perverso, também...aí falei: - Gente, essa aí é interessante! Gostei! Tem uma coisa, existe um ser inteligente aí por trás." (Patricia) 
j) Busca inicial por sexo

Tema relacionado com o acesso às mídias sociais com a intenção de conhecer outras pessoas para possibilidade sexo casual. Nesse tópico, tal objetivo não apareceu de forma clara entre as mulheres, mas os homens foram unânimes com relação à essa finalidade:

"É. O objetivo era transar. Era sexo, de ambas as partes. Era pra ser uma coisa tipo: oi, faz o que tem que fazer, e deu. Só que...foi legal. E aí a gente conversou, aí ele tava indo pra faculdade, também. Eu ofereci carona. E aquilo já gerou uma convivência além do que era esperando pra um simples encontro...a gente foi conversando, foi legal, tinha a aula...depois: - Ah, quer jantar depois da aula? Vamos comer alguma coisa? - E foi, foi...é...foi acontecendo assim, naturalmente..." (Paulo)

"O objetivo era só sexo, mesmo. E a gente começou a conversar, e a gente achou que não ia dar em nada. Porque a gente gostava...a gente...primeiro não tinha pretensão..." (Lucas)

k) Problemas levantados no que se refere ao uso das mídias sociais

Tema relacionado ao mau uso das mídias sociais. Algumas entrevistadas levantaram que homens costumam se identificar como mulheres para ter contato com lésbicas. Entre os entrevistados masculinos, apontou-se eventuais divergências entre os objetivos subjacentes do perfil apresentado e o discurso de homens que querem contato com outros homens:

"Então, aí o lado negro da internet é isso, né? As pessoas se passam pelas pessoas...na época do MSN eu tive o desprazer de adicionar pessoas com nomes de mulheres e quando eu via, era homem. Vi homens pelados! Eu desligava. Tanto que eu nem acionava minha webcam, pra não ver que eu tinha, também. Eu não ligava. Quando eu via, tava a pessoa lá se masturbando. Eu desligava na hora, e bloqueava, e não gostava mais de falar. A gente corre um risco de ser e não ser. Achar, você esperar que ta achando uma pessoa e não é, né. Esse é o lado ruim da internet." (Neia)

"Ia, mas era muito chato. Tinha muita coisa esquisita lá. Tinha uns caras também se fazendo passar por mulher, tinham umas coisas assim.” (Andrea)

"Vou dar um exemplo: Ela tem uma bunda representando ela como personalidade e dizendo que só quer coisa séria. Ah, mas não sei se é...E você abre as fotos e só tem foto de sexo. Ela ta dizendo que quer sexo e tá dizendo que não é bem...uma coisa não bate com a outra. Eu até tenho um ex-namorado, que eu falei pra ele: - olha, ou você publica foto de rosto, ou publica foto de bunda, mas deixe claro o que você tá querendo, porque é difícil a comunicação.” (Rogerio) 
1) Consideram-se um casal ou são casadas(os) em cartório

Tema relacionado à classificação de cada uma/um das(os) componentes da relação como um casal efetivo:

"Houve votos! Então agora eu volto a assinar a minha certidão de casamento - estado civil. Tenho que voltar a colocar casada. Porque fiquei anos divorciada. Agora casada." (Patricia)

"É. Eles não, eles não mencionam termos assim. Eles falam: amigo. Eles não mencionam termos, assim...não sei...mas minha mãe não menciona termos assim, também. Minha mãe não menciona. Quando eu falo marido, ela fica incomodada. Ela: - Companheiro! - E eu: - Não sou Lula, não sou Lula." (Lucas)

"Não tenho problema com esse negócio de nome, não. E o que é estranho, porque primeiro era uma coisa que eu não queria, não tava pensando. E tava bom. Eu acho que se, de repente, falar alguma coisa estraga. Então é melhor deixar acontecer. E aconteceu, mesmo." (Rogerio)

m) Representação social: Homens demoram a se comprometer

Tema que aborda as concepções de cada uma/um das(os) entrevistadas(os) sobre a velocidade do comprometimento masculino em relações amorosas:

"mais freada e desenfreadamente, também. Porque eles pegam hoje um homem, no outro já quer ficar com outro cara...” (Neia)

"Acho que o homem é mais cauteloso pra um lado, assim...Talvez até envolva um pouco de preconceito, assim...sei lá...ter mais facilidade de duas amigas morando juntas...mas a dinâmica que eu vejo dos casais é muito diferente." (Paulo)

n) Representação social: Mulheres se comprometem rapidamente

Tema que aborda as concepções de cada uma/um das(os) entrevistadas(os) sobre a velocidade do comprometimento feminino em relações amorosas:

"As mulheres já querem casar logo de cara. Eu já notei isso. Começa a namorar e já quer morar junto, já quer...sabe...já quer ficar casada.” (Regina)

“Tem a questão clássica, né. Que é...a gente casa, né? A gente casa (risos)...E casa rápido. Mas essa diferença...eu não sei até que ponto isso é mito." (Andrea) 
"Um lar junto. Acho que homem demora um pouco mais pra aceitar. Mas eu vejo, tenho amigos que moram juntos, casados...mas é mais fácil você ver mulher se ajuntando com uma outra mulher do que um homem com outro homem." (Henrique)

o) Participam de ONGs ou movimentos sociais ligados à causa LGBTTT

Tema que aborda a participação das(os) entrevistadas(os) em grupos ou movimentos

LGBTTT. Nenhuma das pessoas entrevistadas disse participar de algum tipo de organização:

"Eu tenho uma preguiça de militância. Sei lá. Preguiça, mesmo. Ficar defendendo causas. Me dá uma agonia." (Andrea)

"Relacionado a movimento gay, LGBT, não! Mas, assim...eu apoio, eu uso as mídias muito pra defender isso, né. Então, tudo que é contra...eu bato, eu coloco muito em discussão, eu uso de uma maneira que a gente defende bastante. O Lucas é a mesma coisa...então, assim, é mais como expressão, mesmo, mas não como um movimento organizado." (Rogerio)

“É, assim, eu não participo de nenhum, até acho interessante, mas assim...tudo a seu tempo. Mas eu uso bem o facebook pra...eu publico tudo que eu acho interessante pros meus amigos, pras pessoas terem conhecimento...que nem todo mundo tem...às vezes, ela tem preconceito porque não conhece sobre aquilo." (Lucas)

\section{Discussão: do virtual ao real - dilemas e desafios}

Os discursos apresentados pelas pessoas entrevistadas apontam para uma boa aceitação no que se refere à própria homossexualidade. Todavia, casos como o da Neia ou do Paulo indicam um forte histórico de dificuldade de auto aceitação e influência negativa da família nesse processo. A experiência dos dois participantes confirma o que já foi constatado por Rodrigues (2012) - o estigma começa no âmbito e no seio do próprio lar.

Todas e todos os participantes se consideram, de uma forma ou de outra, assumidas(os), contudo não em todas as áreas de sua vida. Há uma preocupação, principalmente, no terreno do trabalho, o que confirma o que foi exposto por Castañeda (2007) ao abordar a questão da abertura da sexualidade. Há algo de afirmação, de maturidade, de ser adulta(o) em se assumir, mas com determinadas restrições a certas áreas da vida.

Infelizmente, o preconceito ainda se faz presente. Pelo menos dois dos entrevistados foram vítimas de violência verbal e física por parte da estranhos. Um dos casos foi notificado, enquanto o outro, não. Percebe-se uma subnotificação da violência sofrida por homossexuais, 
apesar de já haver o registro de oito casos diários no Disque 100, conforme a Agência Brasil de Comunicação (2013). Somado a isso, aparece, nas entrevistas, uma preocupação maior no que se refere à discrição no ambiente de trabalho, pelo receio de eventuais discriminações.

O preconceito não apareceu como fator que motivasse o acesso à internet e mídias sociais para conhecer parceiras ou parceiros, mas é uma hipótese que merece ser considerada. O casal Rogério e Lucas mencionou em sua entrevista que tais instrumentos de contato foram essenciais para os gays em geral, apesar de não apresentarem o preconceito como fator propulsor de sua utilização. Aliás, o preconceito mencionado pelo casal foi, ao contrário, o cometido pelos próprios homossexuais, em virtude da misoginia ou padrões heteronormativos ainda utilizados pelos gays, conforme já levantado por Fontes et all (2012), Leal (2013), Miskolsi (2013), Rabelo (2010), e Zago (2013a, 2013b).

O uso de mídias sociais é apresentado como um caminho sem volta, tanto para novos contatos, como para a manutenção das relações existentes. Todas as entrevistadas e entrevistados apontam seu uso como essencial. Significa uma forma a mais de conhecer aspectos, preferências, gostos da outra pessoa, como também um acréscimo aos meios de contato possíveis (Donnamaria \& Terzis, 2012; Silva, 2010). Recados são trocados, lista de compras enviadas, programas são combinados pelas mídias sociais.

Há uma questão de gênero interessante levantada nas entrevistas: os homens ainda parecem procurar inicialmente o sexo, enquanto as mulheres buscariam relações mais estáveis, confirmando os estudos de Castañeda (2007). "Lésbica casa" - foi uma afirmação quase unânime entre os casais entrevistados, homens e mulheres. A divergência foi apresentada pelo casal Rogério e Lucas, mas confessadamente em virtude da falta de contato e conhecimento do universo social das lésbicas.

Outro elemento de gênero apresentado na pesquisa foi a tentativa de contato virtual de homens com as lésbicas. São homens que se passam por mulheres para visualizar a mulher através da webcam. Certamente, há um componente extremamente machista, quando tais homens tentam impor seu contato, principalmente quando mostram sua própria genitália, como se fosse possível uma eventual mudança da sexualidade homoafetiva feminina pela demonstração do falo, do "poderio" masculino. Esse tipo de contato torna-se, assim, uma forma de sedução de caráter disciplinador, impositivo. A ideia por trás parece ser "é porque ela não conhece um homem de verdade que ela é lésbica e eu vou mudar isso".

As representações sociais de gênero, portanto, também se confirmam no seio LGBTTT. Os homens apresentam e buscam virilidade e conquista, elementos históricos e 
sociais associados à masculinidade (Rabelo, 2010). Mulheres seriam mais cuidadoras, apesar da instabilidade emocional aparecer como elemento feminino nas entrevistas. Tais conclusões indicam que há uma repetição de estereótipos de gênero no âmbito da comunidade LGBTTT.

As novas configurações familiares são inegáveis, assim como os efeitos que elas geram. Um dos casais femininos teve sua união registrada em cartório há alguns anos e o outro casal está em vias de concretizar o registro também. A adoção foi outro fator que apareceu como realidade de um dos casais femininos. Os avanços dos setores públicos nessa área são extremamente relevantes. Atualmente, a adoção é considerada mais adequada e tem o procedimento mais célere, caso seja realizada pelo casal homoafetivo, do que se for realizado somente por um dos componentes do casal, conforme exposto por uma das entrevistadas.

Os casais masculinos não demonstraram tal movimentação, apesar de ambos se considerarem em um relacionamento estável. À época das entrevistas, não foi constatada uma preocupação de registro da união (consolidado posteriormente por um dos casais) ou busca por adoção de crianças. Ademais, nas entrelinhas das entrevistas transpareceu uma menor preocupação com a fidelidade. Alguns mantiveram acesso a aplicativos destinados a conhecer outros homens, com cunho de busca por atividade sexual.

O engajamento político na área LGBTTT apareceu de forma indireta. Não há envolvimento em organizações ou instituições destinadas à defesa ou proteção dos direitos e da comunidade LGBTTT. Ficou evidente, no entanto, uma busca pela conscientização de pares ou de amigos, conhecidos e parentes heterossexuais, principalmente utilizando as mídias sociais. Nesse sentido, há conformidade com o descrito por Giddens (2011), que se refere a uma invalidação ou ausência de envolvimento com instituições tradicionais, em função de uma descentralização e atuação de forma mais individual ou em rede.

\section{$\underline{\text { 6. Considerações finais }}$}

Os canais, salas de bate papo ou perfis existentes em mídias sociais podem ter se constituído em um elo extremamente rico de contatos, de formação identitária e de grupo, assim como de construção de possibilidades de vínculos afetivos. As respostas apresentadas pelos casais entrevistados indicam que a mediação de contatos pela internet e mídias sociais veio para ficar. 
Mais do que a discussão sobre virtualidade, sexualidade, fantasias ou ilusões não correspondidas dela decorrentes, o resultado da pesquisa propõe uma reflexão a respeito desse "sair do armário" virtual. A virtualidade permite a aproximação de quem está longe fisicamente ou em virtude de outras barreiras, como o próprio preconceito. Interesses comuns são agregados de forma mais efetiva através de mídias sociais, principalmente por pessoas que não querem se expor.

As atuais vias de comunicação, sem a necessidade de identificação prévia, mas com auto caracterização através de apelidos, pela rede mundial de computadores, ou a criação de perfis nas redes sociais, também sem a referida identificação, permitem novos contatos, diálogos, visibilidade e aceitação da homoafetividade como forma de relação possível. Oportunizam a passagem do segredo para a privacidade, gerando um espaço protegido, até certo ponto seguro, em que o controle dos limites do que pode ser dito ou exposto no ambiente virtual pode se generalizar para a vida real.

A partir do momento que essa pessoa encontra e se conecta (virtual ou fisicamente) a outra com a qual compartilha afinidades, valores e objetivos semelhantes, pode se permitir o encontro, no sentido da união, independentemente do modelo relacional que se busque. Hoje em dia, tal encontro e conexão não se restringe ao início do relacionamento, mas permeia o seu decorrer. Os casais entrevistados deixaram claro a constância da prática do contato virtual, mediante recados, mensagens ou bate-papos com suas companheiras ou companheiros.

A necessidade de contato imediato, a proximidade com o celular e os aplicativos que ele oferece é uma realidade atual, e ao que tudo indica, um elemento que passou a ser visto como fundamental para as relações. "Estando com o seu celular, você nunca está fora ou longe" (Bauman, 2004, p. 78). A dependência dos contatos virtuais por via de aplicativos e mídias sociais é patente, como pode ser verificado nas entrevistas realizadas.

A ausência de necessidade de identificação prévia auxiliaria na própria segurança ou disponibilidade para maior exposição posterior. A utilização da palavra escrita, a intermediação do contato pela tela do computador, celular, tablet, traz maior clareza de intenções, apesar dos eventuais problemas decorrentes de identificações falsas por parte de usuários. Os danos, contudo, parecem ser mais superficiais do que aqueles ocasionados por contatos físicos, já que um simples toque de botão pode afastar permanentemente a outra pessoa do convívio virtual.

O fato é que a presença de meios virtuais como forma de contato e negociação nas relações amorosas atuais parece ser um elemento constante. Observa-se mais efetivamente a 
existência de relacionamentos puros nas relações homoafetivas, conforme descritos por Giddens (1993). Há menos fatores externos de controle e manutenção das relações, que são gerenciadas com base em maior diálogo e intimidade. Independentemente das relações serem mediadas por mídias sociais ou não, a sinceridade e a confiança parecem ser algumas das características mais valorizadas no encontro e na construção do vínculo afetivo com a outra pessoa (Castañeda, 2007).

Toda pesquisa tem limitações. Constatamos a ausência de uma questão relevante e que não feita nas entrevistas: a motivação para o uso das mídias sociais/internet como forma de contato inicial. Vale lembrar que as entrevistas foram realizadas em dupla, com a presença, portanto, de ambos os membros do casal. O uso dessa estratégia pode ter influenciado algumas das respostas. Entrevistas individuais, para compor as informações obtidas com as perguntas apresentadas pela dupla, podem se constituir como um relevante acréscimo aos dados obtidos em pesquisas futuras.

O fato é que o tema é atual e relevante, mas permanece à margem de estudos publicados em periódicos nacionais e internacionais. Os demais artigos que compuseram essa dissertação de mestrado sobre "Influências de mídias sociais na construção de relacionamentos homoafetivos" apontaram para a presença de irrisória produção científica acerca da influência de novas tecnologias na construção e manutenção de relacionamentos afetivos, principalmente quando o foco recai sobre as relações homoafetivas.

A produção de novos trabalhos científicos nessa área cabe, portanto, a nós pesquisadores que nos interessamos por questões de gênero e pelas diversas formas de vivência da afetividade, da sexualidade e da conjugalidade. Há um vasto campo de estudo e uma possibilidade de serviço que pode ser prestado à essa parcela da população que ainda permanece pouco visível social e academicamente - a comunidade LGBTTT. 


\section{REFERÊNCIAS}

Agência Brasil de Comunicação (2013). Oito casos de violência contra homossexuais são denunciados diariamente ao Disque 100. Recuperado em 03 de janeiro de 2014, de http://agenciabrasil.ebc.com.br/noticia/2013-01-03/oito-casos-de-violencia-contrahomossexuais-sao-denunciados-diariamente-ao-disque-100;

Amazonas, M.C.L.A., Lima, A.O., Siqueira, D.F.C.C. \& Arruda, G.F. (2008). Representações de família e material didático. Interamerican Journal of Psychology, 42(2), 236-246. $\begin{array}{llllll}\text { Recuperado em } 20 \text { de novembro de } & \text { 2014, }\end{array}$ http://pepsic.bvsalud.org/scielo.php?script=sci_arttext\&pid=S0034-

96902008000200006\&Ing=pt\&tlng=pt;

Arán, M.; Correa, M. V. (2004). Sexualidade e Política na Cultura Contemporânea: o Reconhecimento Social e Jurídico do Casal Homossexual. Physis. Rio de Janeiro. V. 14, n. 2, jul 2004. Recuperado em 11 de junho de 2014, de http://www.scielo.br/scielo.php?script=sci_arttext\&pid=S0103-

$73312004000200008 \& \operatorname{lng}=\mathrm{en} \& \mathrm{nrm}=$ iso;

Araújo, M. M. X. (2005). Homossexualismo: do preconceito à aceitação. In Contextos Familiares: Associação Gaúcha de Terapia Familiar -AGATEF, ano 2, n. 2;

Bardin, L. (2011). Análise de Conteúdo. Trad. Luís Antero Reto, Augusto Pinheiro. Grupo Almedina;

Bauman, Z. (2004). Amor líquido: sobre a fragilidade dos laços humanos. Trad. Carlos Alberto Medeiros. Cidade: Zahar;

Bozon, M. (2004). A nova normatividade das condutas sexuais ou a dificuldade de dar coerência às experiências íntimas. In Família e Sexualidade. Editora FGV;

Castañeda, M. (2007). A experiência homossexual - explicações e conselhos para os homossexuais, suas famílias e seus terapeutas. Tradução de Brigitte Monique Hervot e Fernando Silva Teixeira Filho. $1^{a}$ Edição. Cidade: A Girafa Editora.

Civiletti, M. V. P.; Pereira, R. (2002). Pulsações contemporâneas do desejo: paixão e libido nas salas de bate-papo virtual. Psicologia, Ciência e Profissão, Brasília, v. 22, n. 1, março 2002. Recuperado em 03 de junho de 2014, de http://pepsic.bvsalud.org/scielo.php?script=sci_arttext\&pid=S141498932002000100006\&lng=es\&nrm=iso;

Dela Coleta, A. S. M., Dela Coleta, M. F., \& Guimarães, J. L. (2008). O amor pode ser virtual? O relacionamento amoroso pela Internet. Psicologia em Estudo, 13(2), 277-285. Recuperado em 14 de março de 2014, de http://www.scielo.br/scielo.php?script=sci_arttext\&pid=S141373722008000200010\&lng=en\&tlng=pt. 10.1590/S1413-73722008000200010; 
Diniz, G. R. S.; Coelho, V. (2005). A história e as histórias de mulheres sobre o casamento e a família. In: Terezinha Féres-Carneiro (Orga.), Família e casal: efeitos da contemporaneidade p. 138-157. Rio de Janeiro: Editora PUC-Rio;

Diniz, G. R. S. (2009). O casamento contemporâneo em revista. In: Terezinha Féres-Carneiro (Orga.), Casal e família: permanências e rupturas, p. 135-156. São Paulo: Casa do Psicólogo;

Donnamaria, C. P., \& Terzis, A. (2009a). O amor caiu na rede: sobre a procura de parceiro e a evolução de vínculos amorosos na Internet. Revista da SPAGESP, 10(2), 45-49. Recuperado em 28 de março de http://pepsic.bvsalud.org/scielo.php?script=sci_arttext\&pid=S1677-

29702009000200008\&lng=pt\&tlng=pt;

Donnamaria, C. P., \& Terzis, A. (2009b). Sobre a evolução de vínculos conjugais originados na Internet. Arquivos Brasileiros de Psicologia, v. 61, n. 3.

Donnamaria, C. P.; Terzis, A. (2012). Algumas notas sobre as relações humanas mediadas por computadores. Mental - ano X - no 18 - Barbacena-MG - jan./jun. 2012 - p. 165-178. Recuperado em 25 de abril de $2014, \quad$ de http://www.redalyc.org/articulo.oa?id=42025969009\#;

Féres-Carneiro, T. (2001). Casamento contemporâneo: construção da identidade conjugal. In: Casamento e Família: do social à clínica. NAU Editora;

Féres-Carneiro, T; Ziviani, C.; Magalhães, A. S. (2009). Arranjos amorosos contemporâneos: sexualidade, fidelidade e dinheiro na vivência da conjugalidade. In: Casal e família: conjugalidade, parentalidade e psicoterapia. Casa do Psicólogo;

Giddens, A. (1993). A transformação da intimidade: sexualidade, amor e erotismo nas sociedades modernas. Trad. Magda Lopes. Editora da Universidade Estadual Paulista;

Giddens, A. (2011). Mundo em descontrole: o que a globalização está fazendo de nós. Trad. Maria Luiza X. de A Borges. 8. Ed. Rio de Janeiro: Record;

Gomes, I. C. (1998). Visão histórica do casamento e sua relação com a formação da família. In: O sintoma da criança e a dinâmica do casal. São Paulo: Editora Escuta;

Goldenberg, M. (2001). Sobre a invenção do casal. In Estudos e Pesquisas em Psicologia. UERJ;

Fontes, O. A; Borelli, F. C.; Casotti, L. M. (2012). Como ser homem e ser belo? Um estudo exploratório sobre a relação entre masculinidade e o consumo de beleza. REAd. Rev. eletrôn. adm. (Porto Alegre), Porto Alegre, v. 18, n. 2, Aug. 2012. Recuperado em 20 de abril de 2014, de http://www.scielo.br/scielo.php?script=sci_arttext\&pid=S141323112012000200005\&lng=en\&nrm=iso;

Isto é Dinheiro (2006). O poderoso mercado gay. Recuperado em 11 jun. 2013, de: http://www.istoedinheiro.com.br/noticias/5534_O+PODEROSO+MERCADO+GAY; 
Jablonski, B. (1998). Até que a vida nos separe. 2. ed. rev. e ampl. Rio de Janeiro: Agir;

Jablonski, B. (2010). A divisão de tarefas domésticas entre homens e mulheres no cotidiano do casamento. Psicologia: Ciência e Profissão, 30(2), 262-275. Recuperado em 15 de agosto de 2014, de http://www.sicelo.br/scielo.php?script=sci_arttext\&pid=S1414989320100002000004\&Ing=en\&tlng=pt. 10.1590/S1414-98932010000200004;

Leal, J. T. B. (2013). Webgay \& Gaymobile: o fluxo da homossexualidade em rede. X POSCOM Seminário dos Alunos de Pós-Graduação em Comunicação Social da PUC-Rio 04, 05 e 06 de novembro de 2013. Recuperado em 04 de abril de 2014, de http://pucposcomrj.com.br/wp-content/uploads/2013/11/Jorge-Tadeu-Borges-Leal.pdf;

Louro, G. L.. (2001). Teoria queer: uma política pós-identitária para a educação. Revista Estudos Feministas,9(2), 541-553. Recuperado em 11 de junho de 2014, de http://www.scielo.br/scielo.php?script=sci_arttext\&pid=S0104-

026X2001000200012\&lng=en\&tlng=pt. 10.1590/S0104-026X2001000200012;

Miskolsi, R. (2013). Machos e brothers: uma etnografia sobre o armário em relações homoeróticas masculinas criadas on line. Estudos Feministas, Florianópolis, 21(1): 424, janeiro-abril/2013. Recuperado em 02 de março de 2014, de https://periodicos.ufsc.br/index.php/ref/issue/view/2105;

Rabelo, A. O. (2010). Contribuições dos Estudos de Género às Investigações que Enfocam a Masculinidade. Ex aequo, Vila Franca de Xira, n. 21. Recuperado em 20 de abril de 2014, de http://www.scielo.gpeari.mctes.pt/scielo.php?script=sci_arttext\&pid=S0874-

55602010000100012\&lng=pt\&nrm=iso;

Rodrigues, R. C. C. (2012). Homofilia e homossexualidades: recepções culturais e permanências. História (São Paulo), 31(1), 365-391. Recuperado em 05 de abril de 2014, de http://www.scielo.br/scielo.php?script=sci_arttext\&pid=S0101-

90742012000100018\&lng=en\&tlng=pt. 10.1590/S0101-90742012000100018;

Sanders, G. L. (2002). O amor que ousa declarar seu nome: do segredo à revelação nas afiliações de gays e lésbicas. In: Os segredos na Família e na Terapia Familiar. Artmed;

Sedgwick, E. K. (2007). A epistemologia do armário. Cadernos Pagu, (28), 19-54. Recuperado em 23 de março de 2014, de http://www.scielo.br/scielo.php?script=sci_arttext\&pid=S0104$83332007000100003 \& \operatorname{lng}=$ en\&tlng=pt. 10.1590/S0104-83332007000100003;

Silva, V. V. A \& Takeuti, N. M. (2010). Do Ciberamor Romântico: Representações Do @mor Num Namoro Virtual. Trabalho apresentado no DT 05 - Comunicação Multimídia do IX Congresso de Ciências da Comunicação na Região Nordeste realizado de 10 a 12 de junho de 2010. Recuperado em 22 de abril de 2014, de http://www.intercom.org.br/papers/regionais/nordeste2010/resumos/R23-0317-1.pdf;

Uziel, A. P. et al (2006). Parentalidade e conjugalidade: aparições no movimento homossexual. Horiz. antropol., Porto Alegre, v. 12, n. 26, Dec. Recuperado em 09 de junho de 2014, de http://www.scielo.br/scielo.php?script=sci_arttext\&pid=S0104$71832006000200009 \& \operatorname{lng}=\mathrm{en} \& \mathrm{nrm}=\mathrm{iso}$; 
Veja.com. (2009). Sites como Orkut e Facebook se firmam como ambientes de sociabilidade. Recuperado em 11 de junho de 2014, de http://veja.abril.com.br/noticia/variedade/sites-comoorkut-facebook-se-firmam-como-ambientes-sociabilidade-420360.shtml;

Viega, S. (2014). Os 5 melhores aplicativos para conhecer lésbicas. Revista on line Umcomo. Recuperado em 01 de junho de 2014, de http://relacoes.umcomo.com.br/articulo/os-5melhores-aplicativos-para-conhecer-lesbicas-3687.html;

Zago, L. F. (2013a). Caça aos homens disponíveis: corpo, gênero e sexualidade na biossociabilidade gay online. Sexualidad, Salud y Sociedad (Rio de Janeiro), (13), 83-98. $\begin{array}{llllll}\text { Recuperado em } & 28 \text { de } & \text { março }\end{array}$ http://www.scielo.br/scielo.php?script=sci_arttext\&pid=S198464872013000100005\&lng=en\&tlng=pt. 10.1590/S1984-64872013000100005;

Zago, L. F. (2013b). "Armários de vidro" e "corpos-sem-cabeça" na biossociabilidade gay online. Interface - Comunicação, Saúde, Educação, 17(45), 419-432. Epub June 14, 2013. $\begin{array}{llllll}\text { Recuperado em } 28 \text { de } & \text { março }\end{array}$ http://www.scielo.br/scielo.php?script=sci_arttext\&pid=S1414$32832013000200014 \& \operatorname{lng}=$ en\&tlng=pt. 10.1590/S1414-32832013005000005. 
ANEXOS 


\section{Termo de Consentimento Livre e Esclarecido - TCLE}

Você está sendo convidado/a a participar de pesquisa que busca compreender o papel das mídias sociais nos relacionamentos interpessoais de natureza homoafetiva. A pesquisa é de responsabilidade de Luiz Fernando Carvalho Maciel, aluno(a) do Curso de Mestrado Acadêmico e da professora Gláucia Ribeiro Starling Diniz, Ph.D., ambos do Programa de Pós-Graduação em Psicologia Clínica e Cultura, Departamento de Psicologia Clínica, Instituto de Psicologia da Universidade de Brasília.

Caso aceite participar, você receberá todos os esclarecimentos necessários antes, durante e após a finalização da pesquisa, e lhe asseguramos que o seu nome não será divulgado, sendo mantido o mais rigoroso sigilo de todos os dados pessoais que permitam identificá-lo(a), a não ser que seja de seu interesse expresso a publicidade de quaisquer dos dados obtidos. Os dados provenientes de sua participação na pesquisa, tais como questionários, entrevistas, arquivos de gravação ou filmagem, ficarão sob a guarda dos pesquisadores responsáveis pela pesquisa, no Laboratório de Saúde Mental e Cultura do Instituto de Psicologia da UnB.

A coleta de dados será realizada por meio de entrevista presencial ou via Skype, se necessário, com uso de gravador e/ou filmagem. Sua participação na pesquisa não implica em nenhum risco. As perguntas poderão gerar reflexão e, caso você sinta necessidade de apoio, deverá solicitar ajuda dos pesquisadores, que poderão encaminhá-lo(a) para serviço de atendimento adequado.

Mesmo não tendo benefícios diretos em participar, indiretamente você estará contribuindo para a compreensão do fenômeno estudado e para a produção de conhecimento científico. Este conhecimento servirá de base para novas pesquisas e possíveis estratégias de apoio à população homoafetiva.

Sua participação é voluntária e livre de qualquer remuneração ou benefício. Você é livre para recusar-se a participar, retirar seu consentimento ou interromper sua participação a qualquer momento. A recusa em participar não irá acarretar qualquer penalidade.

Caso você venha a ter qualquer dúvida em relação à pesquisa, poderá contatar o pesquisador através do telefone (61) 8165-4227 ou pelo e-mail lfmaciel@terra.com.br.

A equipe de pesquisa garante que os resultados do estudo serão devolvidos aos participantes por meio de documento digitalizado. Os resultados da pesquisa poderão ser 
divulgados por meio de apresentações em eventos científicos e publicação escrita (exemplo: artigos e capítulo de livro) para a comunidade científica.

Este projeto foi revisado e aprovado pelo Comitê de Ética em Pesquisa do Instituto de Ciências Humanas da Universidade de Brasília - CEP/IH. As informações com relação à assinatura do TCLE ou os direitos do sujeito da pesquisa podem ser obtidos através do e-mail do CEP/IH cep_ih@unb.br.

Este documento foi elaborado em duas vias, uma ficará com o(a) pesquisador(a) responsável pela pesquisa e a outra com você.

Brasília, de de 2014

Luiz Fernando Carvalho Maciel Matrícula: 120180979
Gláucia Ribeiro Starling Diniz, $\mathrm{PhD}$

Matrícula FUB: 137456

\section{Consinto em participar deste estudo e declaro ter recebido uma cópia deste}

\section{Termo de Consentimento.}

( ) Não desejo ter quaisquer dados divulgados que possam me identificar;

( ) Desejo que apelidos por mim utilizados em mídias sociais sejam expostos no trabalho ou em apresentações que o envolvam;

( ) Desejo que meu nome seja exposto no trabalho ou em apresentações que o envolvam.

Brasília, de de 2014 .

Nome:

CPF: 


\section{Roteiro de entrevista semiestruturada}

Dados das(os) Participantes

Nome

Idade

Sexo

Estado Civil

Escolaridade

Nome

Idade

Sexo

Estado Civil

Escolaridade

Você se considera homossexual?

O que é ser homossexual?

Como foi a aceitação da própria sexualidade?

É assumida(o)?

O que é homofobia?

Já sofreu algum tipo de preconceito/violência em decorrência de homofobia?

A família aceita a sua homossexualidade?

Quais as mídias sociais que utiliza?

Há quanto tempo acessa mídias sociais?

Como e quando o casal se conheceu virtualmente?

Como e quando o casal se conheceu pessoalmente?

Tempo em que o casal se relaciona / Desde quando se consideram em uma relação afetiva?

Considera que houve influência de mídias sociais na construção de seu relacionamento?

Como?

A família conhece a(o) parceira(o)?

A família aceita $\mathrm{a}(\mathrm{o})$ parceira(o)?

O casal mora junto?

Gostaria de acrescentar alguma informação? Qual? 


\section{INSTITUTO DE CIENCIAS HUMANAS / UNIVERSIDADE DE BRASÍLIA / CAMPUS}

\section{PARECER CONSUBSTANCIADO DO CEP}

\section{DADOS DO PROJETO DE PESQUISA}

Título da Pesquisa: Influências de mídias sociais na construção de relacionamentos homoafetivos.

Pesquisador: Luiz Fernando Carvalho Maciel

Área Temática:

Versão: 1

CAAE: 31144514.6 .0000 .5540

Instituição Proponente: Instituto de Psicologia -UNB

Patrocinador Principal: Financiamento Próprio

\section{DADOS DO PARECER}

\section{Número do Parecer: 743.286}

Data da Relatoria: 31/07/2014

\section{Apresentação do Projeto:}

Trata-se do projeto de mestrado intitulado "Influências de mídias sociais na construção de relacionamentos homoafetivos", de autoria do pesquisador Luiz Fernando Carvalho Maciel, do Instituto de Psicologia (IP), da Universidade de Brasília (UnB), cuja hipótese é a de que "a forma de contato e socialização virtual, sem a necessidade de uma identificação inicial, pode apresentar-se como fator significativo para a construção de relacionamentos homoafetivos, para pessoas que não queiram se expor de forma prévia, independentemente das diferenças entre a relação homoafetiva feminina e a relação homoafetiva masculina.

\section{Objetivo da Pesquisa:}

Objetivo Primário:Compreender o uso de mídias sociais na construção de relacionamentos homoafetivos masculinos e femininos.

Objetivo Secundário:

Conhecer a contribuição da virtualidade digital para início de relações homoafetivas; Identificar como a utilização de instrumentos e contatos oferecidos pela virtualidade contribuem para a manutenção das relações homoafetivas; Compreender diferenças no uso dos meios virtuais entre casais homoafetivos masculinos e femininos; Explorar peculiaridades das relações constituídas de forma presencial e de forma virtual.

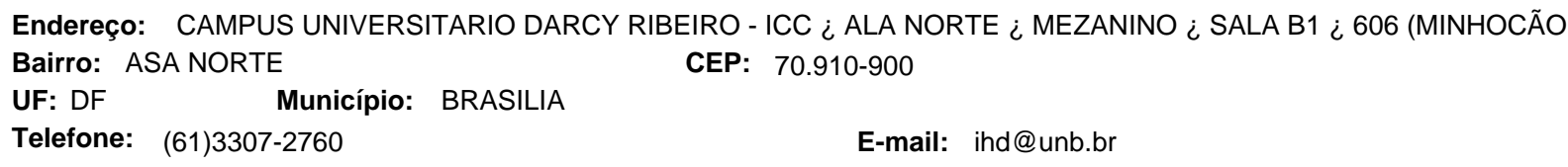




\section{INSTITUTO DE CIENCIAS HUMANAS / UNIVERSIDADE DE BRASÍLIA / CAMPUS}

Continuação do Parecer: 743.286

\section{Avaliação dos Riscos e Benefícios:}

Riscos:

Segundo o pesquisador não há riscos efetivos aos sujeitos da pesquisa.

Benefícios:

Os benefícios da pesquisa está em dar visibilidade a uma realidade já retratada no senso do IBGE de 2010, divulgado em 2012, acerca da existência de relacionamentos homoafetivos e/ou a conjugalidade homoafetiva, que propiciam um novo conhecimento a respeito de novas modalidades de relacionamento.

\section{Comentários e Considerações sobre a Pesquisa:}

Conforme o pesquisador a pesquisa ocorrerá em 3 fases ou etapas, a saber:

A primeira etapa será realizada mediante revisão sistemática da literatura nacional nas bases de dados Scielo e Pepsic (busca de artigos para categorização e analise qualitativa de acordo com os objetivos do estudo, por 2 avaliadores que atuam com questões de gênero). No caso de discordância quanto à inclusão de algum artigo no estudo,uma terceira pessoa capacitada na área de gênero funcionará como juiz. A segunda etapa será constituída por exposição de mídias sociais que oportunizam o contato entre pessoas do mesmo sexo (apresentação e quantificação dos meios de contato oferecidos pela rede virtual). A terceira etapa, por sua vez, consiste de dados a serrem coletados mediante entrevistas semiestruturadas com 8 (oito)casais homoafetivos, de forma presencial ou virtual (A coleta de dados será realizada por meio entrevista presencial ou via Skype), se necessário, com uso de gravador e filmagem, para posterior análise de conteúdo,conforme técnica de Bardin. Em termos de método de orientação teórica, pretende o pesquisador se apoiar em teorias de base feministas. Os sujeitos serão escolhidos mediante critérios de inclusão e de exclusão.

Critério de Inclusão:

Os grupos escolhidos para as entrevistas se constituirão de quatro casais do sexo feminino e quatro do sexo masculino, e dentre cada um dos dois grupos, serão selecionados casais que tenham conhecido a/o companheira(o) e mantido seu relacionamento com a influência de mídias sociais e casais que tenham conhecido a/o cônjuge e mantido o relacionamento homoafetivo precipuamente de forma presencial. Os(as) sujeitos(as) da

pesquisa serão escolhidos(as) através de amostra de conveniência.

Critério de Exclusão:

Serão excluídas da amostra ou pesquisa aquelas pessoas que não se sentirem confortáveis com o

Endereço: CAMPUS UNIVERSITARIO DARCY RIBEIRO - ICC ¿ ALA NORTE ¿ MEZANINO ¿ SALA B1 ¿ 606 (MINHOCÃO Bairro: ASA NORTE UF: DF Município: BRASILIA

Telefone: (61)3307-2760

CEP: $70.910-900$

E-mail: ind@unb.br 


\section{INSTITUTO DE CIENCIAS HUMANAS / UNIVERSIDADE DE BRASÍLIA / CAMPUS}

Continuação do Parecer: 743.286

seu objeto ou eventual exposição de sua vida pessoal, em que pese a ausência de identificação de seus participantes. Tampouco participarão aquelas que não considerem ter vivenciado um relacionamento homoafetivo, em virtude das características da própria relação.

\section{Considerações sobre os Termos de apresentação obrigatória:}

Dentre a documentação anexada à plataforma, o pesquisador anexou seu curriculo lattes e o do seu orientador,carta de encaminhamento, carta de revisão ética, justificativa de aceite institucional (em razão da pesquisa envolver uma amostra de conveniência e ser realizada na própria instituição virtualmente ou por meio presencial), TCLE completo e detalhado, onde o pesquisador menciona que manterá guarda e sigilo em relação a gravações,filmagens e materiais de pesquisa coletados. O pesquisador apresentou, ainda, instrumentos de pesquisa com orientação para a busca de artigos e as questões as serem realizadas na entrevista semiestruturada. O pesquisador anexou, ainda, autorização para uso de voz e imagem dos sujeitos da pesquisa, separada do TCLE. Por fim, apresentou um cronograma atualizado.

\section{Recomendações:}

Não há recomendações.

\section{Conclusões ou Pendências e Lista de Inadequações:}

Considerando que o pesquisador atendeu as pendências relativas ao último parecer (postadas no dia 10/7/2014) - esclarecimento sobre a utilização da imagem e da voz dos sujeitos na pesquisa e também anexação da autorização para uso de voz e imagem, separada do TCLE - o parecer é favorável à aprovação do projeto.

\section{Situação do Parecer:}

Aprovado

\section{Necessita Apreciação da CONEP:}

Não

\section{Considerações Finais a critério do CEP:}

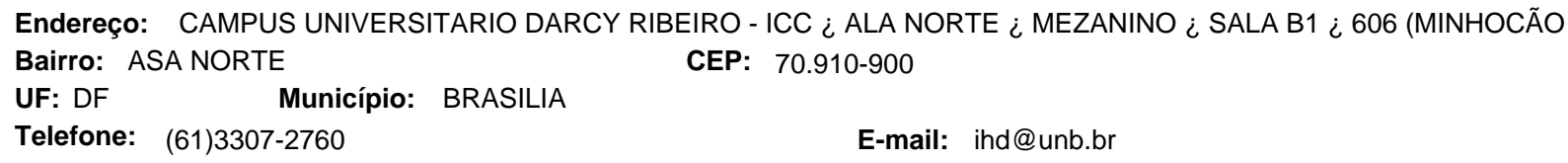




\section{INSTITUTO DE CIENCIAS HUMANAS / UNIVERSIDADE DE BRASÍLIA / CAMPUS}

BRASILIA, 08 de Agosto de 2014

Assinado por:

Lívia Barbosa

(Coordenador)

Endereço: CAMPUS UNIVERSITARIO DARCY RIBEIRO - ICC ¿ ALA NORTE ¿ MEZANINO ¿ SALA B1 ¿ 606 (MINHOCÃO

Bairro: ASA NORTE

CEP: $70.910-900$

UF: DF

Município: BRASILIA

Telefone: (61)3307-2760

E-mail: ind@unb.br 